\title{
MORPHOLOGY AND TAXONOMY OF LARVAE OF THE GENUS HYDRYPHANTES KOCH, 1841 (ACARI, HYDRACHNIDIA, HYDRYPHANTIDAE) IN RUSSIA
}

\author{
Petr V. Tuzovsky \\ Institute for Biology of Inland Waters, Russian Academy of Sciences, Borok, Nekouz. Distr., \\ Yaroslavl Prov., Russia \\ E-mail: tuz@ibiw.yaroslavl.ru
}

\begin{abstract}
This study presents a taxonomic review of water mite larvae of the genus Hydryphantes Koch, 1841 (Hydryphantidae) found in the fauna of Russia during the long-term survey period of 1974-2016. The review includes (re)descriptions and illustrations of 14 Hydryphantes species found in the country: H. clypeatus (Thor, 1899), H. crassipalpis Koenike, 1914, H. dispar (Schaub, 1888), H. hellichi Thon, 1899, H. ildensis Tuzovskij, 2016, H. nonundulatus Thon, 1899, H. octoporus Koenike, 1896, H. placationis Thon, 1899, H. planus Thon, 1899, H. prolongatus Thon, 1899, H. ruber (Geer, 1778), H. ruberoides Tuzovskij, 1990, H. samaricus Tuzovskij, 2014, and H. tenuipalpis Thor, 1899.
\end{abstract}

KEY WORDS: Hydryphantidae, Hydryphantes, morphology, larvae, females, identification keys, Russia.

DOI: 10.21684/0132-8077-2016-24-2-181-233

\section{INTRODUCTION}

The word fauna of the genus Hydryphantes currently includes over 100 species and subspecies (K. O. Viets 1987). The water mites of the genus are free-living in standing waters, also temporary pools, ditches and rarely in running waters. From the territory of the former USSR, the following 19 species were recorded by Sokolow (1940): $H$. (Hydryphantes) affinis Sokolow, 1931, H. (Hydryphantes) bayeri Pisarovic, 1896, H. (Hydryphantes) clypeatus, H. (Hydryphantes) crassipalpis, $H$. (Hydryphantes) dispar, H. (Hydryphantes) fontinalis Sokolow, 1936, H. (Hydryphantes) frici Thon, 1899, H. (Hydryphantes) hellichi, H. (Hydryphantes) intermedius Daday, 1901, H. (Hydryphantes) peroviensis Udaltsow, 1907, H. (Hydryphantes) placationis, H. (Hydryphantes) planus, H. (Hydryphantes) ruber, H. (Hydryphantes) tataricus Daday, 1901, H. (Polyhydryphantes) dröscheri Koenike, 1903, H. (Polyhydryphantes) flexuosus Koenike, H. (Polyhydryphantes) octoporus Koenike, 1896, H. (Polyhydryphantes) skorikowi, and H. (Polyhydryphantes) thoni. However, the taxonomic status of some named species remains not clear. Lundblad (1962) synonymized $H$. affinis, H. bayeri, and H. clypeatus with H. planus, and $H$. hellichi with $H$. ruber. Di Sabatino et al. (2009) synonymized $H$. intermedius with $H$. dispar and treated $H$. bayeri, $H$. clypeatus, $H$. frici, and $H$. peroviensis as a species incerta.

Investigations of water mites from different regions of Russia over the past 30 years allowed me to describe three more species: Hydrypantes ruberoides Tuzovskij, 1990 from Magadan Province and Kamchatka (Tuzovskij 1990, 2003), H. samaricus Tuzovskij, 2014 from Samara Province and Yaroslavl Province (Tuzovskij 2014), and $H$. ildensis Tuzovskij, 2016 from Yaroslavl Province (Tuzovskij 2016). In addition, three more species have been found in the territory of the Yaroslavl Province: $H$. tenuipalpis, $H$. nonundulatus and $H$. prolongatus (Tuzovskij 2008, 2015a, 2015b, respectively). H. tenuipalpis and $H$. prolongatus also have been recorded from Western Siberia (Stolbov 2010).

Larvae are known not of all named species. Morphology of Hydryphantes larvae has been described for the following taxa: H. bayeri (Biesiadka and Cichocka 1990), H. crassipalpis (Wainstein 1980; Biesiadka and Cichocka 1990), $H$. dispar (Sparing 1959), H. frici (Biesiadka and Cichocka 1990), H. hellichi (Biesiadka and Cichocka 1990), H. peroviensis (Biesiadka and Cichocka 1990), H. placationis (Wainstein 1980), H. planus (Wainstein 1980, Biesiadka and Cichocka 1990), H. ruber (Piersig 1897-1900; Koenike 1908; Viets 1936; Prasad and Cook 1972; Wainstein 1980; Biesiadka and Cichocka 1990), H. thoni (Biesiadka and Cichocka 1990), H. flexuosus (Imamura 1954). The descriptions of the larvae usually are incomplete and insufficiently illustrated, complicating identification of species.

Larvae of Hydryphantes species are known to parasitize imagos of Hemiptera (Aphididae), Thysanoptera (Thripidae), Diptera (Chironomidae and Mycetophilidae) (Smith and Oliver 1986) and Odonata (Coenagrionidae) (Zawal and Dyatlova 2008), on which they attach to the thorax region or, rarely, the abdomen. Early records concerning 
larval parasitism of Hydryphantes species on $\mathrm{Cu}-$ licidae probably were based upon misindetified euthyadine species (Smith and Oliver 1986). The females were identified using the original descriptions and papers of Viets (1936), Sokolow (1940), Lundblad (1962), Gerecke (1996), and Di Sabatino et al. $(2009,2010)$.

The purpose of this paper is to study the morphology of larvae of the genus Hydryphantes collected in Russia and to give an identification key to the larvae and the females, from which these larvae were reared. The females and males of this genus do not exhibit external sexual dimorphism, but mature females usually larger than males.

\section{MATERIAL AND METHODS}

The mite specimens were collected by the author in the European and Asian parts of Russia in 1974-2016. To obtain larvae, the water mites were maintained in laboratory (room temperature, natural day-night conditions). Eggs and larvae obtained from females were kept individually in glass or transparent plastic vessels of 10-15 mm diameter, and height of $15 \mathrm{~mm}$. Specimens were not fixed in Koenike liquid, but slides were made from the fresh material. The larvae were not dissected, and in females the gnathosoma was mounted in a position that allowed investigating capitulum and pedipalps in lateral view. All mite specimens were mounted in Hoyer's medium.

Idiosomal setae are named according to Tuzovskij (1987): Fch-frontales chelicerarum, $\mathrm{Fp}$-frontales pedipalporum, $\mathrm{Vi}$-verticales internae, $\mathrm{Ve}$-verticales externae, $\mathrm{O} i$ - occipitales internae, $\mathrm{Oe}$-occipitales externae, $\mathrm{Hi}$-humerales internae, $\mathrm{He}$-humerales externae, $\mathrm{Hv}$-humerales ventralia, $\mathrm{Sci}$ - scapulares internae, $\mathrm{Sce}$-scapulares externae, $L i$-lumbales internae, $L e$-lumbales externae, $S i$-sacrales internae, $S e$ - sacrales externae, $\mathrm{Ci}$-caudales internae, $\mathrm{Pi}$ - praeanales internae, $P e$ - praeanales externae, $A i$-anales internae, $A e$ - anales externae.

Furthermore, the following abbreviations are used: P-1-5, pedipalp segments (trochanter, femur, genu, tibia and tarsus); I-Leg-1-6, first leg, segments 1-6 (trochanter, basifemur, telofemur, genu, tibia and tarsus) i. e. III-Leg- $3=$ genu of third leg; $\mathrm{C} 1$ - coxal seta located medially on coxa I, C2coxal seta located posterolaterally on coxa I, C4coxal seta located anteromedially on coxa III; acs - acanthoid seta, $e$ - eupathidium, $s$ - solenidion; I-Leg-6: $d e$ - distance between the anterior end of segment and eupathidium, $d s$ - distance between the anterior end of segment and solenidion; genital acetabula (ac.1-ac.3); L-length, W-width, Ddiameter; $n$-number of specimens measured; all measurements are given in micrometers $(\mu \mathrm{m})$.

\section{RESULTS}

\section{Family Hydryphantidae Piersig, 1896}

\section{Genus Hydryphantes Koch, 1841}

Diagnosis. Larva. Color red. Anterior part of dorsum with a relatively large plate provided a pair of simple setae ( $V i)$ and pair of thrichobothria $(O i)$, paired with small platelets each bearing the simple seta $F c h$ and the trichobothria $F p$. Trichobothria $F p$ are very long, thin, and usually well extending beyond posterior margin of plate, $\mathrm{O} i$ very short and thin. Lateral eye lenses on each side separated and located in soft integument. Coxal plates I to III small, separate, with three pairs of coxal setae (C3 on coxal plate II absent). Chelicerae striated and very stout, chela short and edentate. Pedipalp fivesegmented, P-4 with large dorsodistal bifurcate claw, number of setae on P-1-5: 0, 1, 2, 3, 4, 8(s). Legs I to III six-segmented and each with three claws, the lateral ones extremely thin. All legs simple setae usually strong and pectinate, specialized setae thin and smooth.

\section{Hydryphantes clypeatus (Thor, 1899)}

(Figs. 1-16)

Material examined. Larvae $(n=26)$ were reared from four females collected in a sedge bog near village Postyltsevo, Nekouz District, Yaroslavl Province: two females 25 May 2000, one female 1 June 2002, and one female 10 June 2004. The duration of the embryonic period was $12-15$ days.

Diagnosis. Larva. Distance between bases of trichobothria $\mathrm{Oi}$ larger than their length; all dorsal hysterosomal setae subequal; excretory pore plate wider than long; urstigma wider than long; posterior margin of coxal plate II convex; P-5 solenidion longer of segment; I/II-Leg-4 solenidion 2.0-2.5 times longer than eupathidium, I/II-Leg-5 with unequal solenidia; I-Leg- $6 d e<d s$.

Description. Larva. Anterior pair of platelets small, more or less triangular, posterior plate relatively large, anteriorly narrow, posteriorly widening; median eye weakly developed and situated between setae $V i$ (Fig. 1). Both pairs of trichobothria thin, $F p$ very long, $O i$ short. Distance between bases of trichobothria $O i$ larger than their length. 


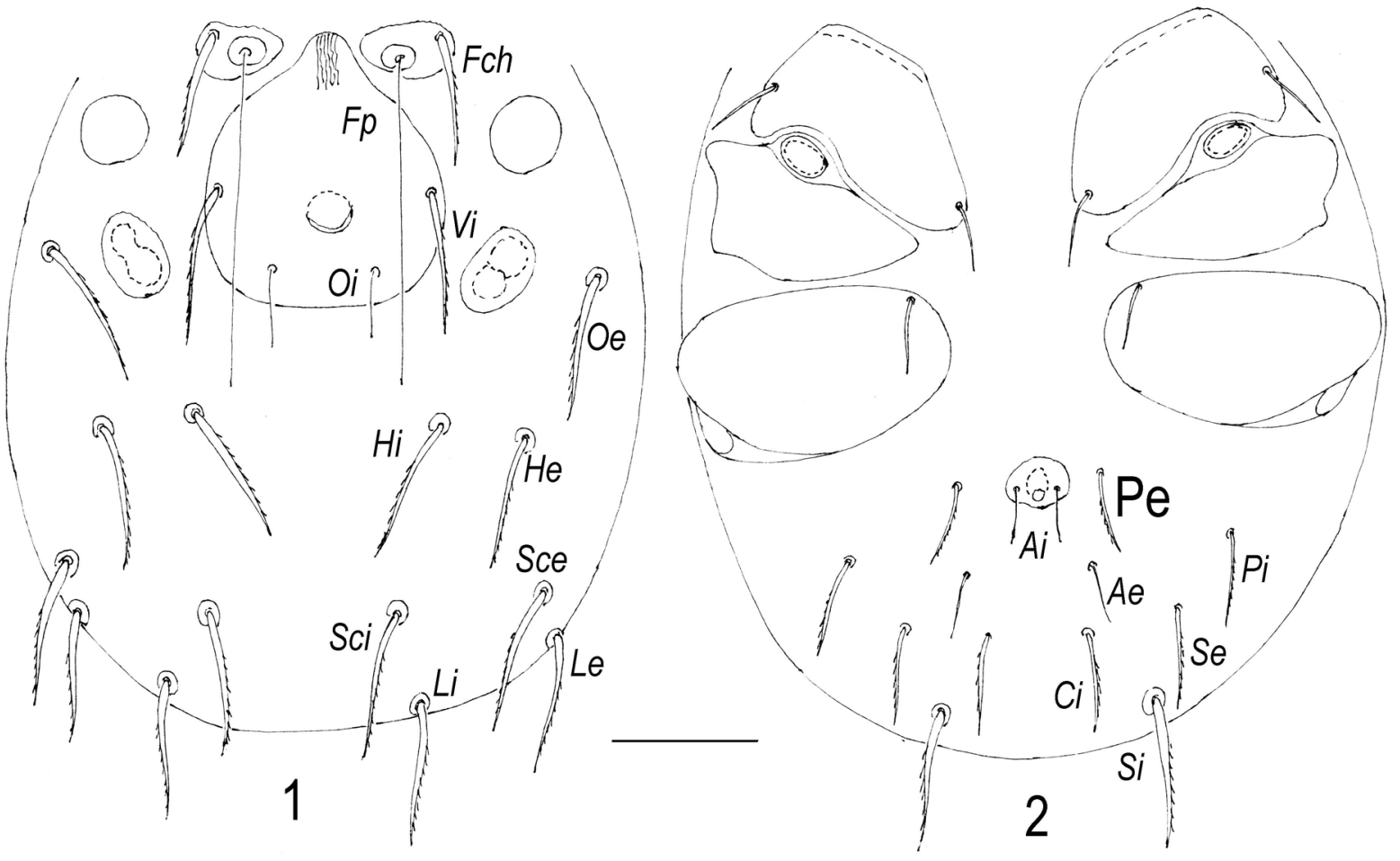

Figs. 1-2. Hydryphantes clypeatus Thor, 1899, larva: 1 -dorsal view; 2 - ventral view. Scale bar: $1-2=20 \mu \mathrm{m}$.

Simple proterosomal setae (Fch and $V i$ ) thick, but $F c h$ slightly shorter than $V i$. Other dorsal setae $(O e$, $\mathrm{Hi}, \mathrm{He}, \mathrm{Sci}$, Sce, $\mathrm{Li}$, and $\mathrm{Le}$ ) thick and approximately equal in length. Lateral eyes with anterior lenses large and circular, posterior lenses elongate.

Coxal plates II triangular, coxal plates I and III more or less trapezoidal and rounded medially (Fig. 2); all coxal setae relatively short and subequal. Urstigma rather large, wider than long. Setae $S i$ slightly longer than other ventral idiosomal setae. Setae $S e, C i$, $P i$, and $P e$ subequal and slightly longer and thicker than both pairs of anal setae. Excretory pore plate small and wider than long, L/W ratio 1.15-1.30 (Figs. 3-5). Bases of setae Ai near middle or in posterior portion of excretory pore plate.

Chelicera with large basal segment and small chela. Basal segment of chelicera (Fig. 6) with a few rather wide strips.

Pedipalps stout (Fig. 7): P-2 large, with convex dorsal margin and a single dorsoproximal seta; P-3 with two subequal setae (proximal and distal); P-4 with three thin subequal setae and large dorsodistal claw; P-5 solenidion longer of segment.

Legs 6-segmented. Shape and arrangement of specialized setae on terminal leg segments as shown in Figs. 8-10. I/II-Leg-4 solenidia 2.0-2.5 times longer than eupathidia; I/II-Leg-5 with two proximal unequal solenidia; I-Leg-6 de shorter than $d s$; IILeg-6 solenidion in proximal, eupathidium in sub- medial position. Claw of leg III slightly larger than claws of legs I and II. Lateral claws shorter and thinner than the strong empodial claw (Fig. 11).

Measurements, $\mathrm{n}=10$. Dorsal plate L 45-48, W 41-44; setae Fch L 21-23, setae Fp L 62-69, setae Vi L 28-32, setae $\mathrm{Oi}$ L 8-10, setae Oe, Hi, He, Sci, $\mathrm{Sce}, \mathrm{Li}, \mathrm{Le}$, and $\mathrm{Si} \mathrm{L}$ 26-28; setae $\mathrm{Se}, \mathrm{Ci}, \mathrm{Pi}$, and $\mathrm{Pe}$ 16-18; setae $A i$ and $A e$ L 13-14; distance between setae $\mathrm{Vi}-\mathrm{Vi}$ 31-35, distance between setae $\mathrm{Oi}-\mathrm{Oi}$ 17-20; excretory pore plate L 6-9, W 10-12; basal segments of chelicera L 68-73, chela L 13-14; strips on basal segment of chelicera W 0.5-0.7; pedipalpal segments (P-1-5) L: 6-7, 27-29, 22-25, 15-19, 10-11; legs segments L: I-Leg-1-6: 23-27, 18-24, 15-19, 25-28, 32-37, 62-65; II-Leg-1-6: 22-25, 17-19, 11-13, 16-19, 30-32, 46-50; III-Leg-1-6: $22-25,17-23,12-15,20-23,33-37,45-48$.

Female. Integument soft with rather long rounded papillae (Fig. 12). Frontal plate (Fig. 13) compact and nearly quadrate, anterior margin slightly convex or obtuse-angled, lateral margins concave, posterior margin straight, lateral and posterior extensions short, posterior projections short. Median eye small and situated slightly posterior to anterior setae.

Capitulum (Fig. 14) with equally S-shaped ventral margin and rather long rostrum. Chelicera (Fig. 15) slender, basal segment with obtuse-angled hump near middle, cheliceral stylet moderately in length. 

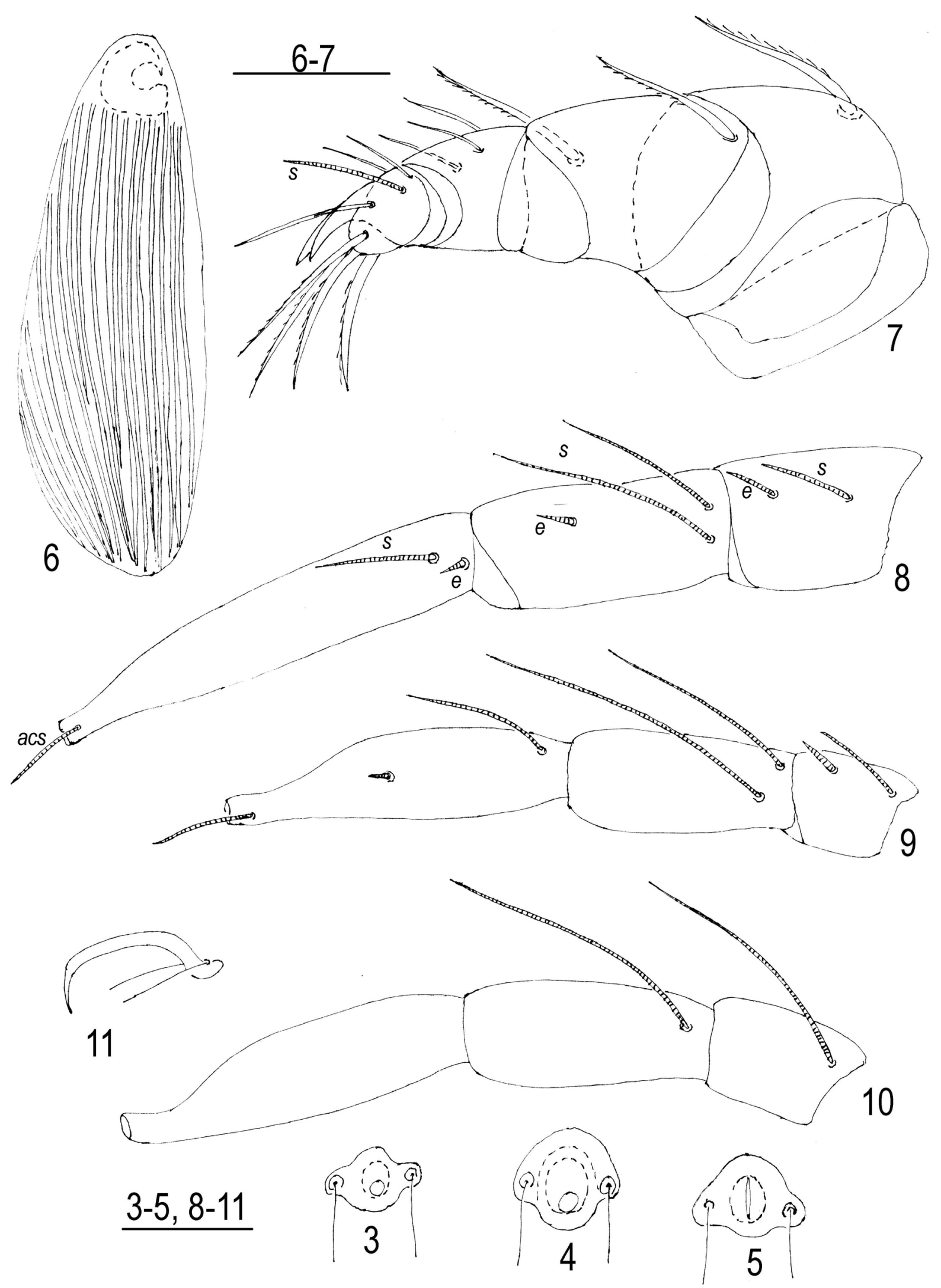

Figs. 3-11. Hydryphantes clypeatus Thor, 1899, larva: 3-5-excretory pore plate; 6-chelicera, dorsal view; 7pedipalp, ventrolateral view; 8-I-Leg-4-6; 9-II-Leg-4-6; 10-III-Leg-4-6; 11-claws of leg III. Simple setae on I-III-Leg-4-6 are not shown. Scale bars: $100 \mu \mathrm{m}$. 


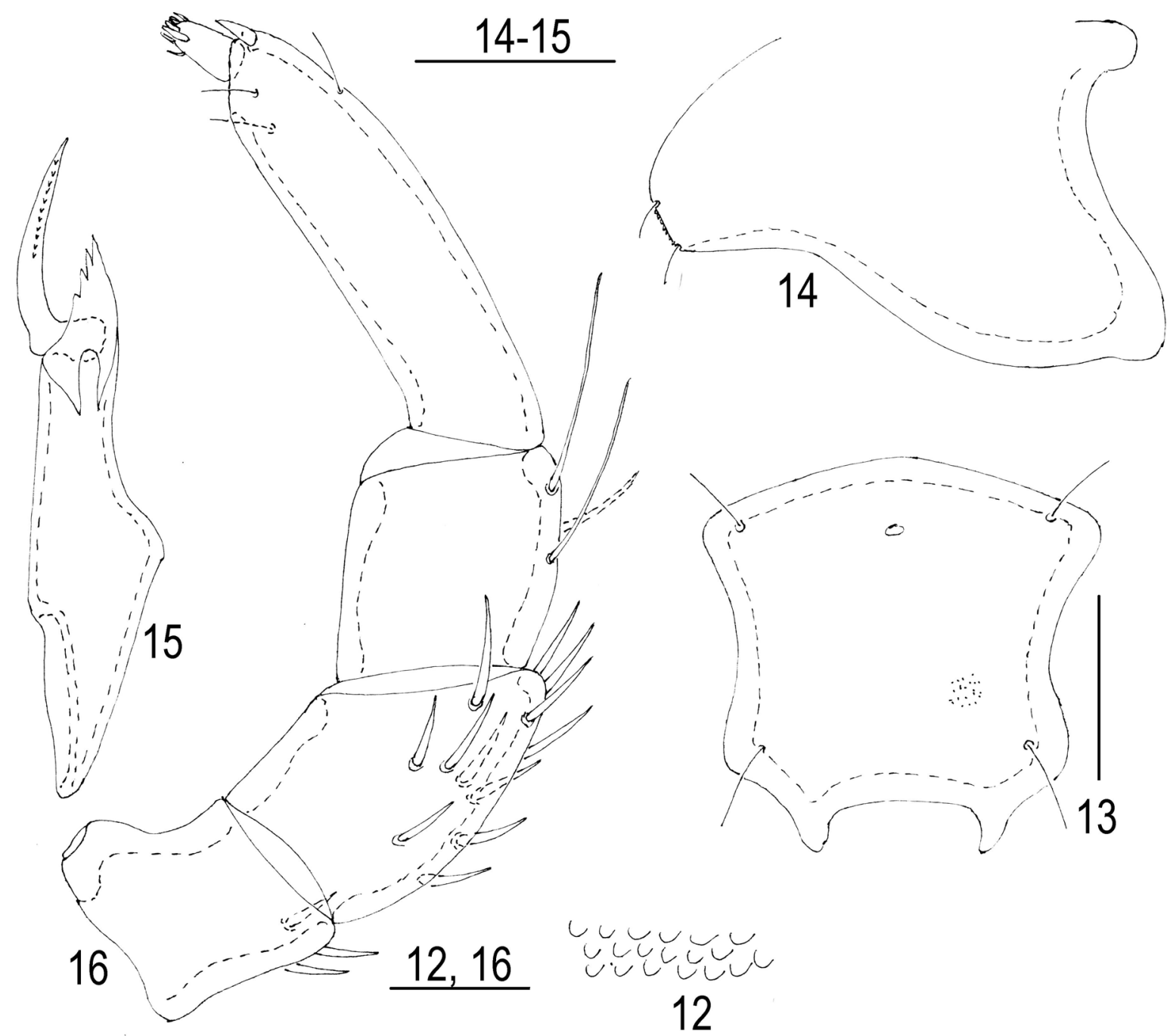

Figs. 12-16. Hydryphantes clypeatus Thor, 1899, female: 12 - fragment of integument; 13 - frontal plate; 14 - capitulum; 15-chelicera; 16 - pedipalp. Scale bars: 12, 16=50 $\mu \mathrm{m}, 14-15=100 \mu \mathrm{m}, 13=200 \mu \mathrm{m}$.

Pedipalp slender (Fig. 16): P-1 with 3-4 dorsodistal setae; P-2 with 10-13 setae; P-3 usually with two long dorsodistal setae but sometimes present 3 setae (two long setae and single short seta); P-4 slender with three thin distal setae and short thick dorsodistal spine.

Measurements, $\mathrm{n}=5$. Idiosoma L 1100-1400; dorsal plate L 360-400, W 360-390; genital flaps L 235-250, W 110-125; genital acetabula (ac.1ac.3) L 35-42, 25-30, 55-63; capitulum L 275290, rostrum L 55-63, chelicera L 360-375, chela L 120-125; pedipalpal segments (P-1-5) L: 62-75, 110-120, 60-90, 185-200, 25-30; legs segments L: I-Leg-1-6: 75-90, 110-135, 135140, 210-220, 235-250, 250-265; II-Leg-1-6: 100-105, 125-140, 160-175, 275-290, 325-340, 325-350; III-Leg-1-6: 95-105, 125-140, 170180, 285-300, 325-340, 330-340; IV-Leg-1-6:
180-190, 185-200, 250-265, 400-415, 285-400, 335-350.

Remarks. Lundblad (1962) considered $H$. clypeatus, as well as the species and subspecies $H$. baeyeri Pisarivic, 1896, H. bayeri nonundulatus Viets, 1919, H affinis Sokolow, 1931, and H. ruber tuxeni Motas, 1961 as a junior synonyms of $H$. planus Thon, 1899. However, clear differences can be found both in the larvae and females of $H$. clypeatus. The larva is similar to the larva of $H$. planus (see description of this species). However, the latter differs from H. clypeatus in: (1) the posterior margin of the coxal plate II straight (Fig. 140), not convex; (2) the excretory pore plate is longer than wide (Figs. 141-142); (3) P-5 with short solenidion (Fig. 144); (4) I-Leg-6 solenidion slightly shorter than eupathidium (Fig. 145), ILeg-6 de as long as $d s$. 
Hydryphantes crassipalpis Koenike, 1914

(Figs. 17-33)

Material examined. Larvae $(n=26)$ were reared from four females collected in sedge bog near village Postyltsevo, Nekouz District, Yaroslavl Province: two females 25 May 2000, one female 1 June 2002 and one female 10 June 2004. The duration of the embryonic period was 12-15 days.

Diagnosis. Larva. Distance between bases of trichobothria $O i$ larger than their length, median eye situated between setae $V i$, setae Fch and $V i$ subequal, all dorsal hysterosomal setae subequal; excretory pore plate as long as wide or slightly wider than long, basal segment of chelicera with numerous thin strips, P-4 with two subequal clawlets; P-5 solenidion shorter of segment; I/IILeg-4 solenidion 1.5-2.0 times longer than eupathidium; I/II-Leg-5 with unequal solenidia; ILeg-6 $d e<d s$.

Description. Anterior pair of platelets more or less triangular, posterior plate narrows anteriorly and widens posteriorly; median eye weakly developed (usually hardly visible) and situated between setae Vi (Fig. 17). Both pairs of trichobothria thin, $F p$ very long, $O i$ short. Distance between bases of trichobothria $O i$ larger than their length. Simple proterosomal setae ( $F c h$ and $V i$ ) thick and subequal. Other dorsal setae (Oe, Hi, He, Sci, Sce, $\mathrm{Li}$, and $\mathrm{Le}$ ) thick and approximately equal in length. Anterior lateral eyes large circular, posterior lateral eyes elongate.

Coxal plates II triangular, coxal plates I and III more or less trapezoidal and rounded medially (Fig. 18); all coxal setae subequal. Urstigma relatively large and situated on anterior edge of coxal plate II near its middle. Setae $S i$ a little longer than other ventral idiosomal setae. Setae $\mathrm{Se}, \mathrm{Ci}, \mathrm{Pi}, \mathrm{Pe}$, and both pairs of anal setae subequal in length. Excretory pore plate as long as wide or slightly wider than long, L/W ratio 1.0-1.1 (Figs. 19-21), bases of setae $A i$ located anteriorly to excretory pore.

Chelicera with large basal segment and small chela. Basal segment of chelicera (Fig. 22) with a few thin strips.

Pedipalps stout (Fig. 23): P-2 large with convex dorsal margin and a single dorsoproximal seta; P-3 with two subequal setae (proximal and distal); P-4 with three thin unequal setae and large claw with subequal clawlets; P-5 solenidion shorter of segment.

Shape and arrangement of specialized setae on terminal legs segments as shown in Figs. 24-26. I/ II-Leg-4 solenidion 1.5-2.0 times longer than eupathidium, I/II-Leg-5 with two proximal unequal solenidia; I-Leg-6 de shorter than $d s$; II-Leg-6 solenidion in proximal, eupathidium in submedial position. Claw of leg III (Fig. 27) slightly larger than claws of legs I and II (Fig. 28).

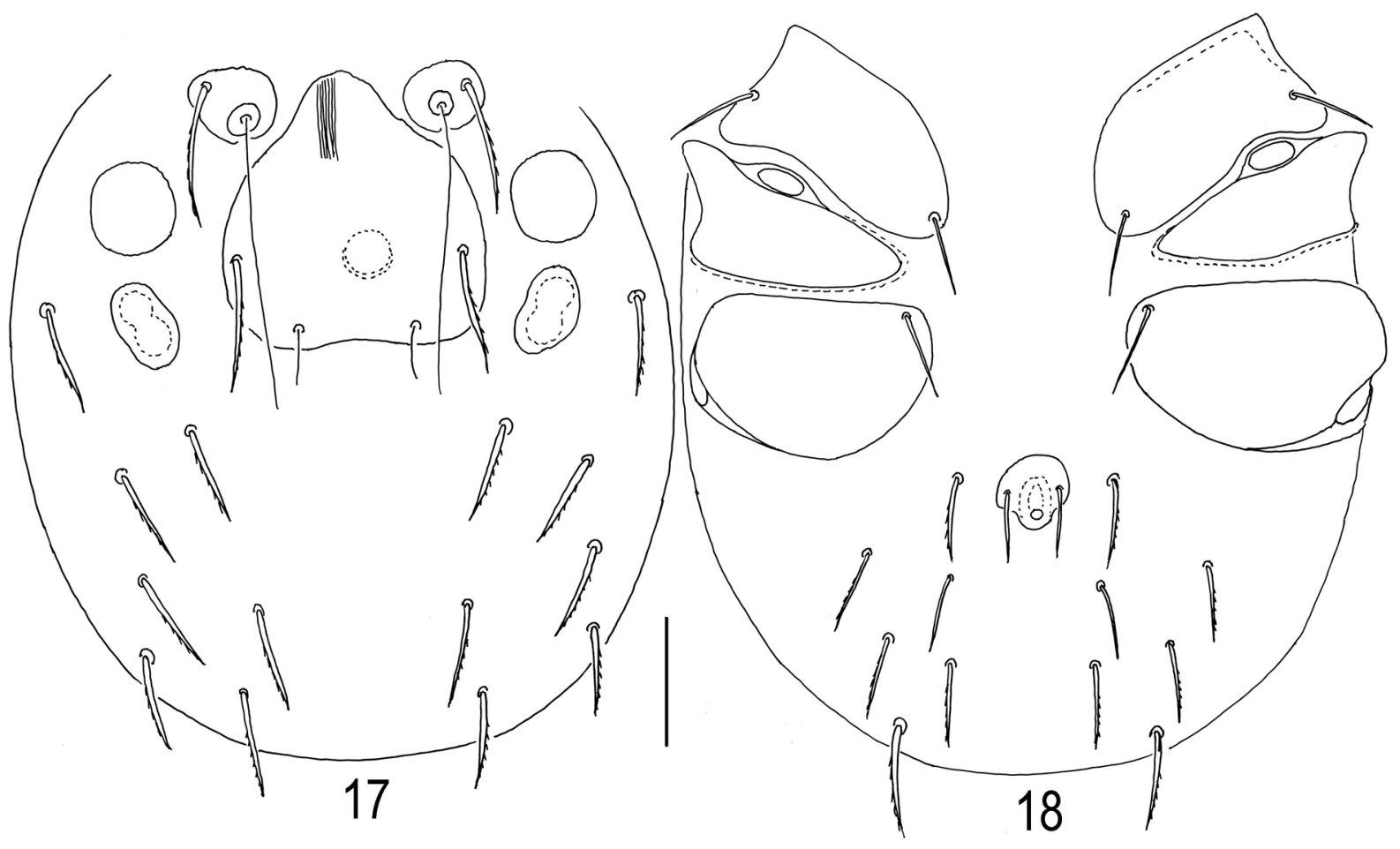

Figs. 17-18. Hydryphantes crassipalpis Koenike, 1914, larva: 17-dorsal view; 18_ventral view. Scale bar: $20 \mu \mathrm{m}$. 


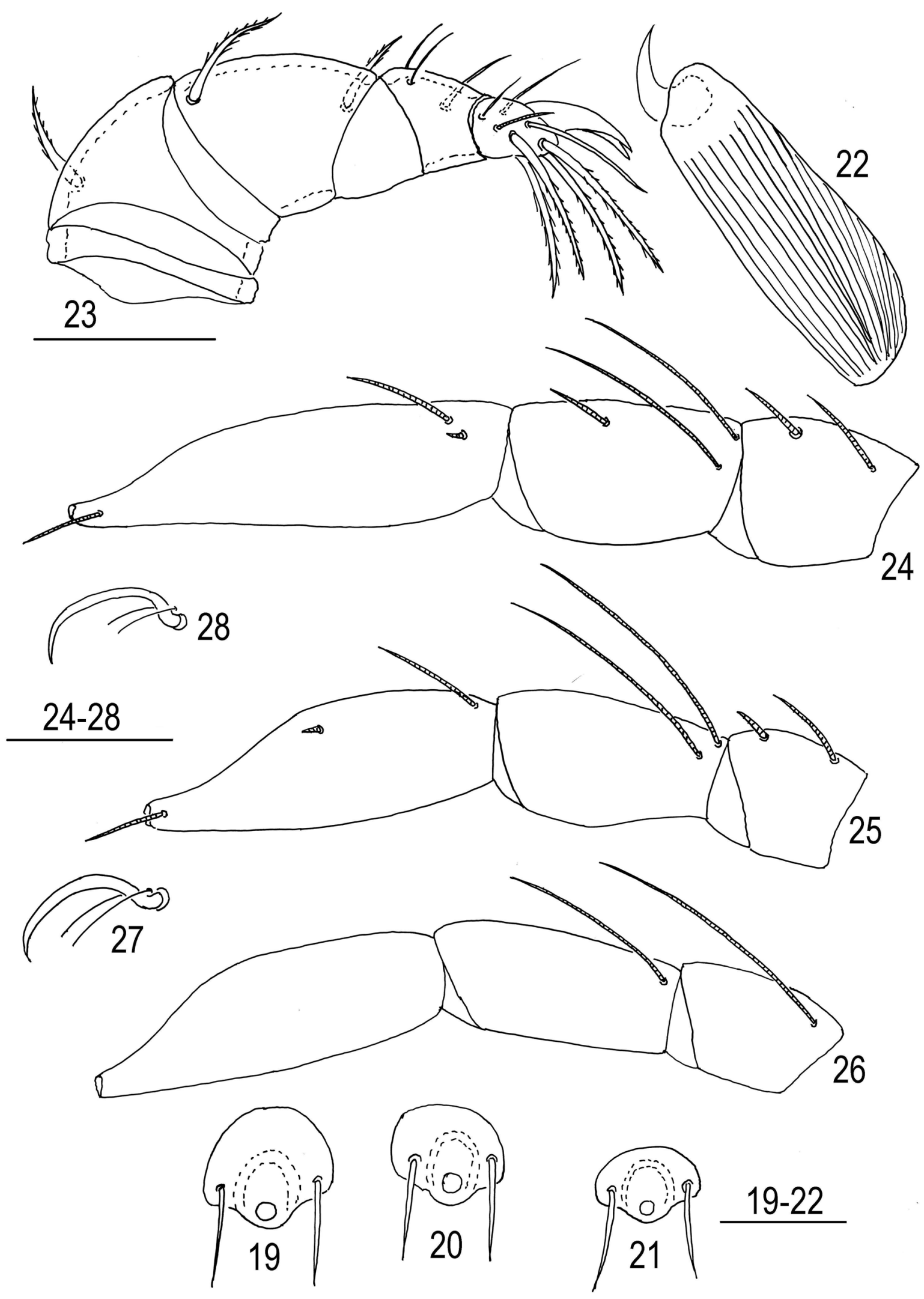

Figs. 19-28. Hydryphantes crassipalpis Koenike, 1914, larva: 19-21—excretory pore plate; 22 - chelicera, dorsal view; 23-pedipalp, lateral view; 24-I-Leg-4-6; 25-II-Leg-4-6; 26-III-Leg-4-6; 27—claws of leg III; 28—claw of leg I. Simple setae on I-III-Leg-4-6 are not shown. Scale bars=100 $\mu \mathrm{m}$. 


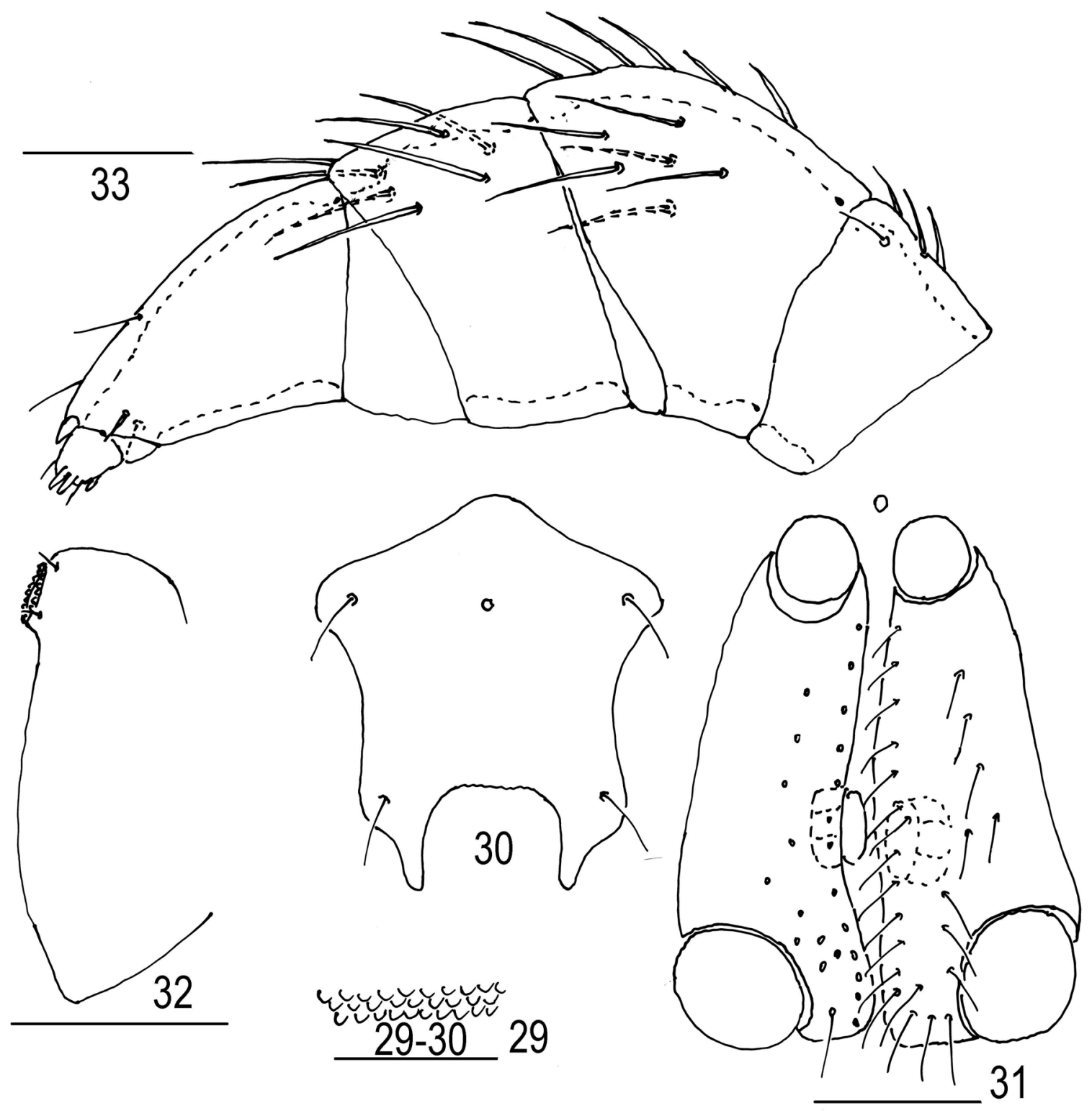

Figs. 29-33. Hydryphantes crassipalpis Koenike, 1914, female: 29-fragment of integument; 30 -frontal plate; 31genital field; 32 - capitulum; 33 - pedipalp. Scale bars: 12, 16=50 $\mu \mathrm{m}, 14-15=100 \mu \mathrm{m}, 13=200 \mu \mathrm{m}$.

Measurements, $\mathrm{n}=10$. Dorsal plate L 38-42, $\mathrm{W}$ 40-42; setae Fch L 20-23, setae Fp L 41-45, setae Vi L 17-19, setae Oi L 10-12, setae Oe, Hi, He, Sci, Sce, Li, and Le L 18-19, Si L 16-17; setae Se, $\mathrm{Ci}, \mathrm{Pi}$, and $\mathrm{Pe}$ 12-14; setae $A i$ and $A e$ L 10-12; distance between setae $V i-V i$ 33-35, distance between setae $\mathrm{Oi}-\mathrm{Oi}$ 15-19; excretory pore plate L 8-12, W 10-12; basal segments of chelicera L 53-56, chela L 8-12; pedipalpal segments (P-1-5) L: 5-6, 23-28, 20-23, 13-16, 10-12; legs segments L: I-Leg-1-6: 18-20, 15-19, 13-16, 20-22, 25-27, 43-46; II-Leg-1-6: 20-23, 13-17, 9-14, 12-17, 22-25, 35-38; III-Leg-1-6: 21-24, 11-14, 10-12, 15-18, 22-25, 36-38.
Female. Integument soft with rounded papillae (Fig. 29). Frontal plate (Fig. 30) compact, nearly pentagonal in shape due to a bluntly pointed anteromedial projection, posterior margin straight or slightly concave, posterior projections moderately in length. Median eye small and situated slightly posterior to anterior setae. Genital flap elongate (L/W ratio 1.9-2.0), with large posterior acetabulum (Fig. 31).

Capitulum (Fig. 32) with equally S-shaped ventral margin and short rostrum.

Pedipalp (Fig. 33) extremely robust: P-1with 3-4 dorsodistal setae; P-2 with 10-13 setae; P-3 with four to seven dorsodistal setae; P-4 strong 
tapering distally, with four thin distal setae and short thick dorsodistal spine.

Measurements, $\mathrm{n}=4$. Idiosoma L 1500-1950; dorsal plate L 425-515, W 424-490; genital flap L 265-350, W 125-150; genital acetabula (ac.1-ac.3) L 37-50, 25-50, 45-65; capitulum L 275-325, rostrum L 35-50, chelicera L 250-275, chela L 100-115; pedipalpal segments (P-1-5) L: 70-75, 110-125, 75-90, 135-150, 35-40; legs segments L: I-Leg-1-6: 90-115, 125-140, 135-150, 250265, 275-290, 275-305; II-Leg-1-6: 90-130, 135-150, 160-195, 325-340, 385-415, 375-390; III-Leg-1-6: 90-125, 135-150, 185-200, 325-345, 385-400, 350-375; IV-Leg-1-6: 200-230, 210$225,300-315,500-515,500-525,375-400$.

\section{Hydryphantes dispar (Schaub, 1888)}

(Figs. 34-48)

Material examined. Larvae $(n=13)$ were reared from a single female collected in a sedge bog near village Koltsovo, Stavropol District, Samara Province, 5 May 1998, leg. P. V. Tuzovskij. The duration of the embryonic period was 15 days.

Diagnosis. Larva. Distance between bases of trichobothria $\mathrm{Oi}$ larger than their length; setae $H i$, $\mathrm{Sci}$, and $\mathrm{Li}$ longer than $\mathrm{Oe}, \mathrm{He}$, Sce, and $\mathrm{Le}$; median eye situated between rows setae $V i$ and $O i$; excretory pore plate usually as long as wide or slightly longer than wide; P-5 with long solenidion; I/II-Leg-4 solenidia 2.0-2.5 times longer than eupathidia; I/IILeg-5 with subequal solenidia; I-Leg-6 $d e>d s$.

Description. Larva. Idiosoma oval, anterior pair of platelets triangular or oval, trichobothria $F p$ long and slightly extending beyond posterior margin dorsal plate (Fig. 34). Posterior plate anteriorly narrow, posteriorly widening; median eye rather large and situated between rows of setae $\mathrm{Vi}$ and $\mathrm{Oi}$; seta $\mathrm{Vi}$ thick and slightly longer than $\mathrm{Fch}$; $\mathrm{Oi}$ short, distance between $\mathrm{Oi}-\mathrm{O} i$ larger than their length. Medial dorsal setae ( $H i, S c i$ and $L i)$ a little longer than lateral setae ( $\mathrm{Oe}, \mathrm{He}$, Sce and $\mathrm{Le}$ ).

Coxal plates II small, coxal plates I and III large, more or less trapezoidal and rounded medially (Fig. 35); all coxal setae relatively short and subequal. Urstigma oval, wider than long, moderate in size. Setae $S i$ longer and thicker than other ventral idiosomal setae. Setae $\mathrm{Se}, \mathrm{Ci}, \mathrm{Pi}$, and $\mathrm{Pe}$ subequal and slightly longer and thicker than both pairs of anal setae. Excretory pore plate small, usually as long as wide or slightly longer than wide (Figs. 36-37), excretory pore situated near posterior margin of plate. Bases of setae $A i$ situated anterior to excretory pore.

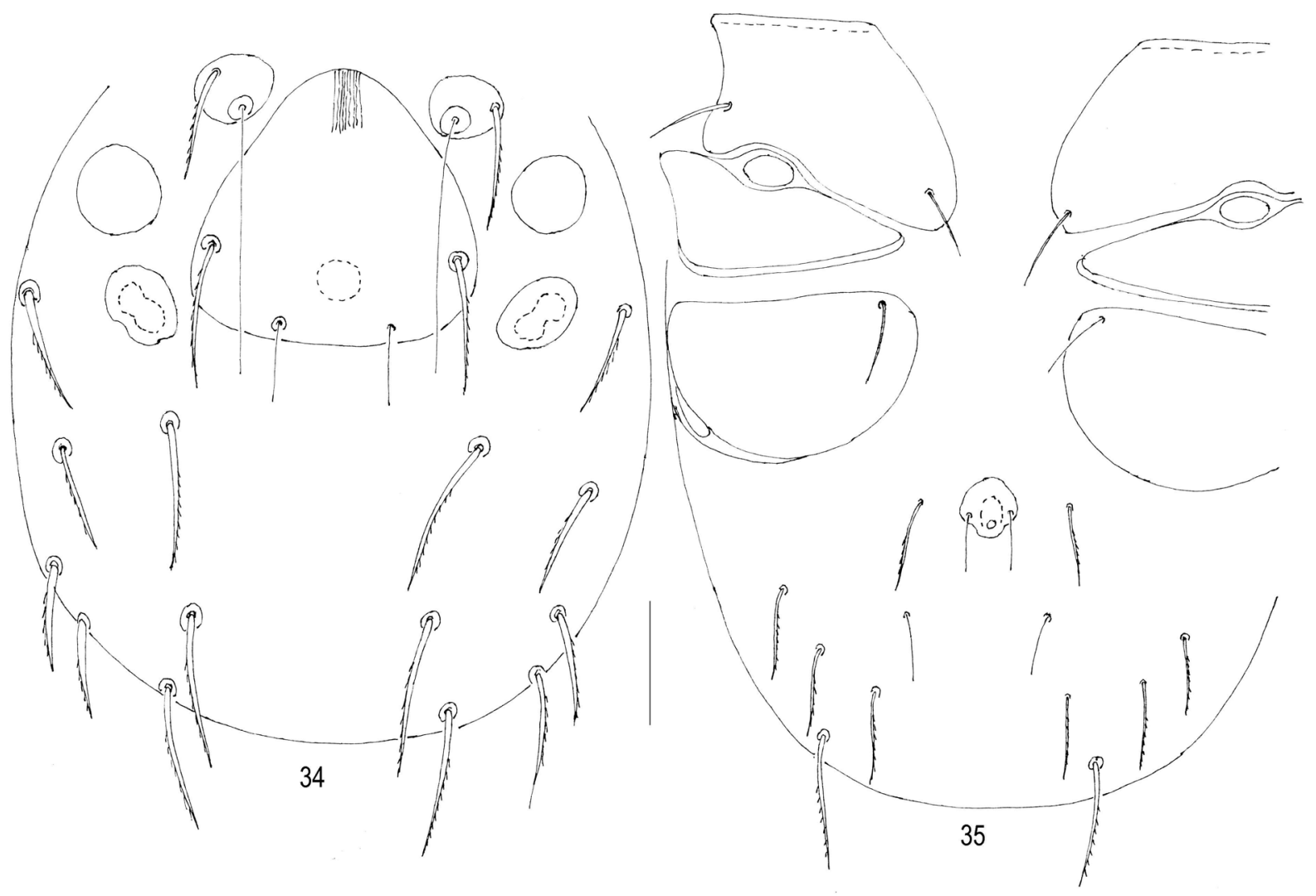

Figs. 34-35. Hydryphantes dispar (Schaub, 1888), larva: 24-dorsal view; 25-ventral view. Scale bar: $20 \mu \mathrm{m}$. 


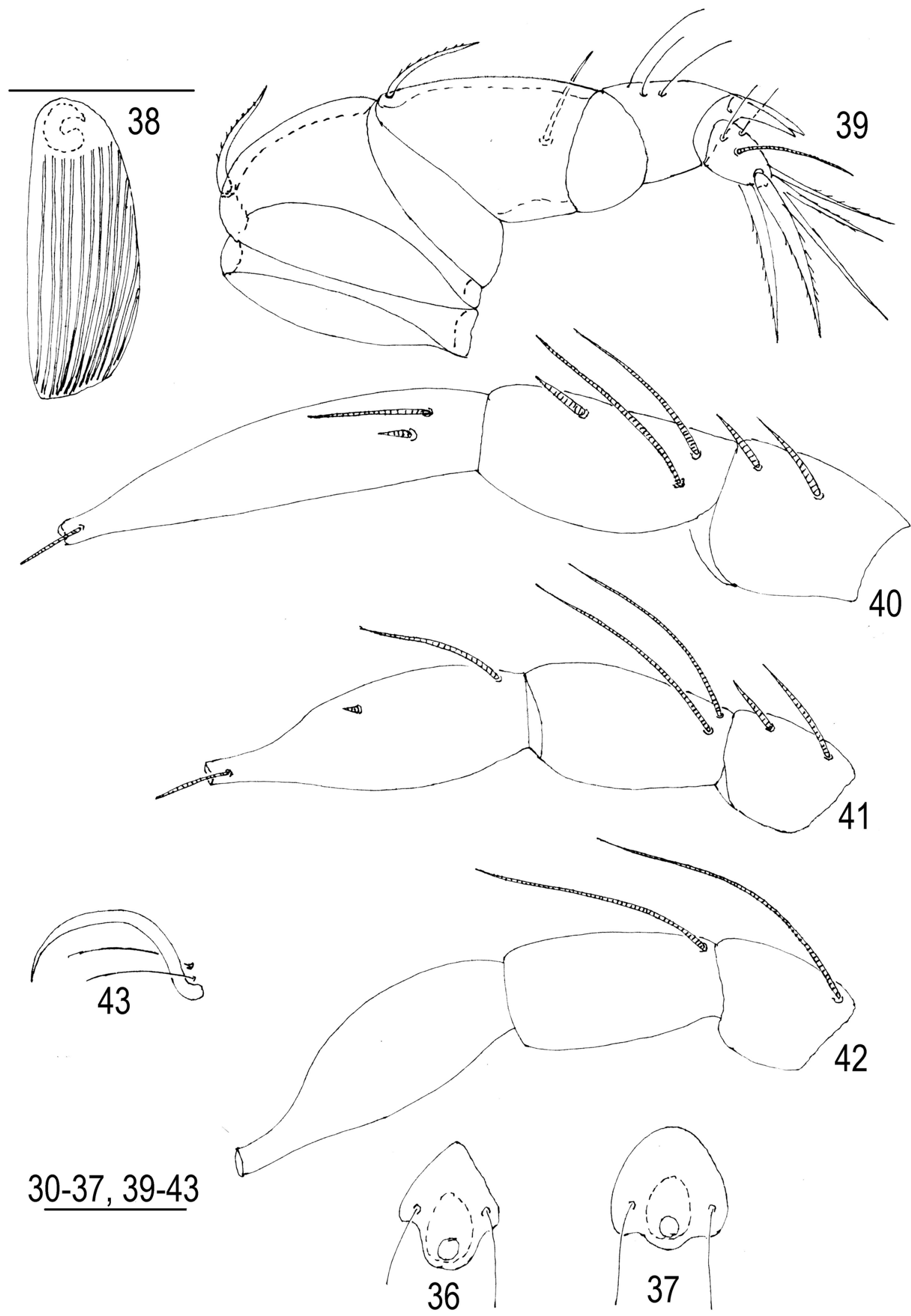

Figs. 36-43. Hydryphantes dispar (Schaub, 1888), larva: 36-37-excretory pore plate; 38 - chelicera, dorsal view; 39-pedipalp, lateral view; 40-I-Leg-4-6; 41-II-Leg-4-6; 42-III-Leg-4-6; 43-claws of leg III. Simple setae on I-III-Leg-4-6 are not shown. Scale bars: $36-37,39-43=50 \mu \mathrm{m}, 38=50 \mu \mathrm{m}$. 

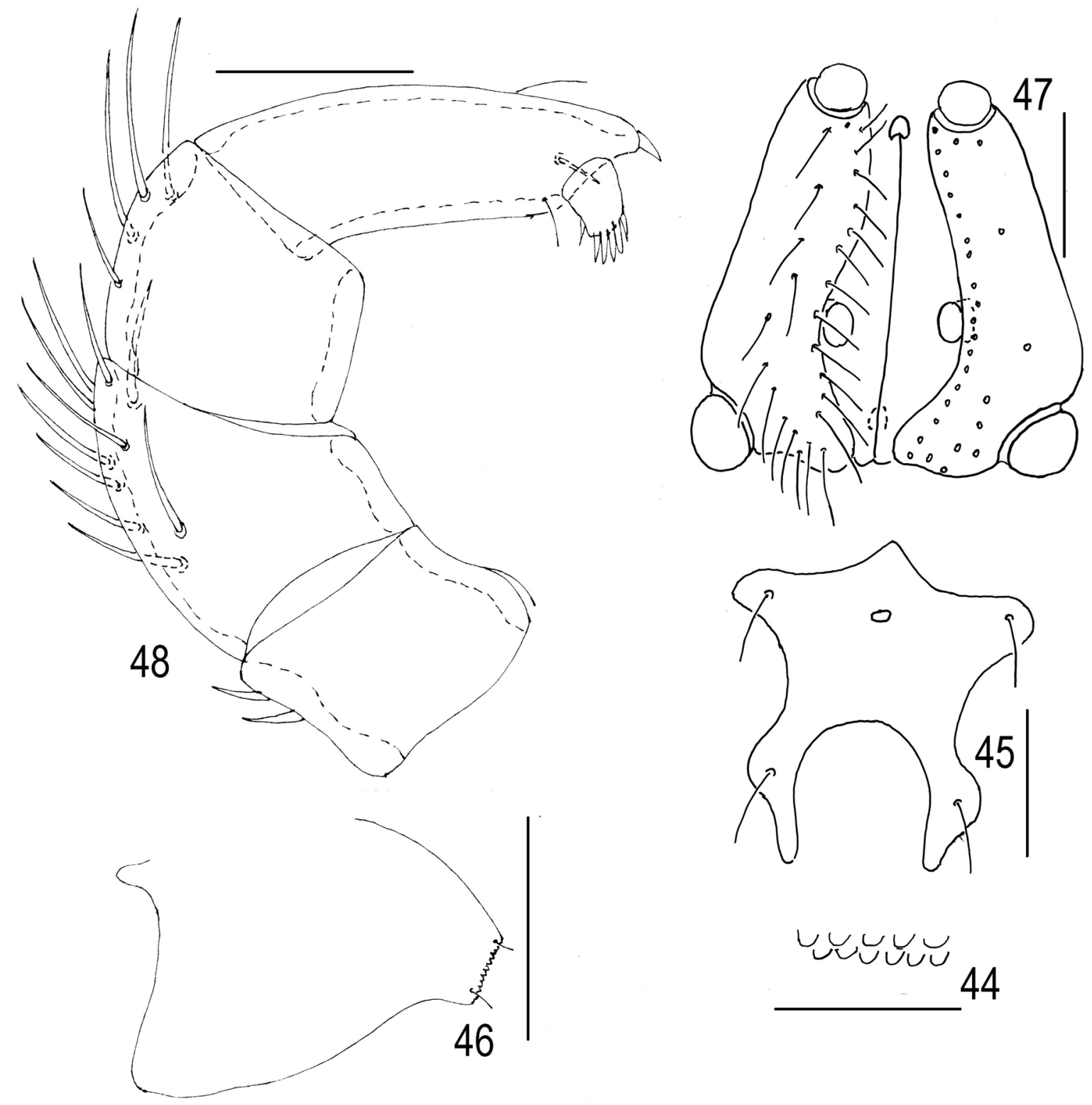

Figs. 44-48. Hydryphantes dispar (Schaub, 1888), female: 44-fragment of integument; 45-frontal plate; 46capitulum; 47—genital field; 48 —pedipalp. Scale bars: 44=50 $\mu \mathrm{m} ; 45,46=200 \mu \mathrm{m} ; 47,48=100 \mu \mathrm{m}$.

Chelicera with large basal segment and small chela (Fig. 38). Basal segment with chelicera with a few rather wide strips.

Pedipalps stout (Fig. 39): P-2 large with convex dorsal margin and a single dorsoproximal seta; P-3 with two subequal setae (proximal and distal); P-4 with three thin unequal setae and a large dorsodistal bifurcate claw with two slightly unequal clawlets; P-5 solenidion longer of segment.

Shape and arrangement of specialized setae on terminal legs segments as shown in Figs. 40-42. I/ II-Leg-4 solenidia 1.5-2.0 times longer than eupathidia, I/II-Leg-5 both proximal solenidia subequal in length, I-Leg-6 eupathidium short and situated distal to solenidion basis; II-Leg-6 solenidion proximal, eupathidium is submedial; III-Leg-4 proximal solenidion longer than III-Leg-5 proximal solenidion. Empodium large and crescent-shaped on all tarsi, ambulacra short and thin (Fig. 43).

Measurements, $\mathrm{n}=10$. Dorsal plate L 41-47, W 43-48; setae Fch L 18-23, setae Fp L 43-48, setae $V i$ L 21-27, setae $O i$ L 10-13, distance between setae $\mathrm{Vi}-\mathrm{Vi}$ 40-46, distance between setae $\mathrm{Oi}-\mathrm{O} i$ 17-21; setae $\mathrm{Hi}$, Sci, $\mathrm{Li}$, Si L 22-26, setae Oe, L, $\mathrm{He}$, Sce, and $\mathrm{Le}$ L 16-19; setae Ci, Se, Pi, Pe 12-16; setae $A i$ and $A e$ 9-10; excretory pore plate L 9-14, W 7-12; urstigma L 6-8, W 9-11; basal segments of chelicerae L 62-73, chela L 15-16; pedipalpal segments (P-1-5) L: 5-6, 27-31, 20-24, 11-13, 10-12; leg segments L: I-Leg-1-6: 21-23, 15-19, 
16-18, 22-26, 28-30, 53-57; II-Leg-1-6: 21-24, 16-18, 11-13, 15-18, 22-26, 43-46; III-Leg-1-6: 21-24, 15-16, 10-13, 17-19, 22-28, 40-44.

Female. Integument soft with short rounded papillae (Fig. 44). Frontal plate (Fig. 45) with a bluntly pointed medioanterior projection, prominent anterolateral extensions, lateral and posterior margins concave, posterior projections long; median eye small and situated nearly on the level of anterior pair of setae.

Capitulum (Fig. 46) with equally S-shaped ventral margin and short rostrum (base of capitulum/rostrum L 5.0-6.7).

Genital plates (Fig. 47) elongate, with 20-30 thin setae on each side; posterior acetabula moderately in size.

Pedipalp (Fig. 48) robust: P-1 with one to three dorsodistal setae; P-2 with 8-12 setae; P-3 with three to four setae; P-4 rather slender with three thin distal unequal setae and a short, thick dorsodistal spine.

Measurements, $\mathrm{n}=5$. Idiosoma L 1300-2040; dorsal plate L 475-500, W 430-450; genital flap L 250-275, W 110-120; genital acetabula (ac.1-ac.3) L 35-40, 30-37, 60-65; capitulum L 265-275, rostrum L 35-45; chelicera L 360-375, chela L 120-125; pedipalpal segments (P-1-5) L: 75-85, 130-140, 75-90, 170-180, 30-32; leg segments L:
I-Leg-1-6: 85-100, 110-125, 150-165, 250-265, 250-275, 260-275; II-Leg-1-6: 85-100, 110-125, 185-200, 320-335, 360-375, 335-350; IIILeg-1-6: 100-110, 150-160, 200-215, 310-325, 355-375, 325-350; IV-Leg-1-6: 210-225, 200$215,300-315,435-450,410-425,335-350$.

\section{Hydryphantes hellichi Thon, 1899 = Hydryphantes planus Wainstein (1980)}

(Figs. 49-67)

Material examined. Larvae $(n=65)$ were reared from three females collected in a sedge bog near village Postyltsevo, Nekouz District, Yaroslavl Province: one female 20 June 2001 and two females 25 May 2002. The duration of the embryonic period was $12-15$ days.

Diagnosis. Larva. Posterior plate pentagonal, wider than long, distance between bases of trichobothria $\mathrm{Oi}$ larger than their length; median eye situated between setae $V i$; all dorsal hysterosomal setae subequal; excretory pore plate wider than long; basal segment of chelicera with wide strips; posterior margin of coxal plate II slightly convex; P-5 solenidion longer of segment; I-Leg-4 solenidion and eupathidium equal in length, ILeg-6 $d e=d s$; II-Leg-4 solenidion longer than eupathidium.
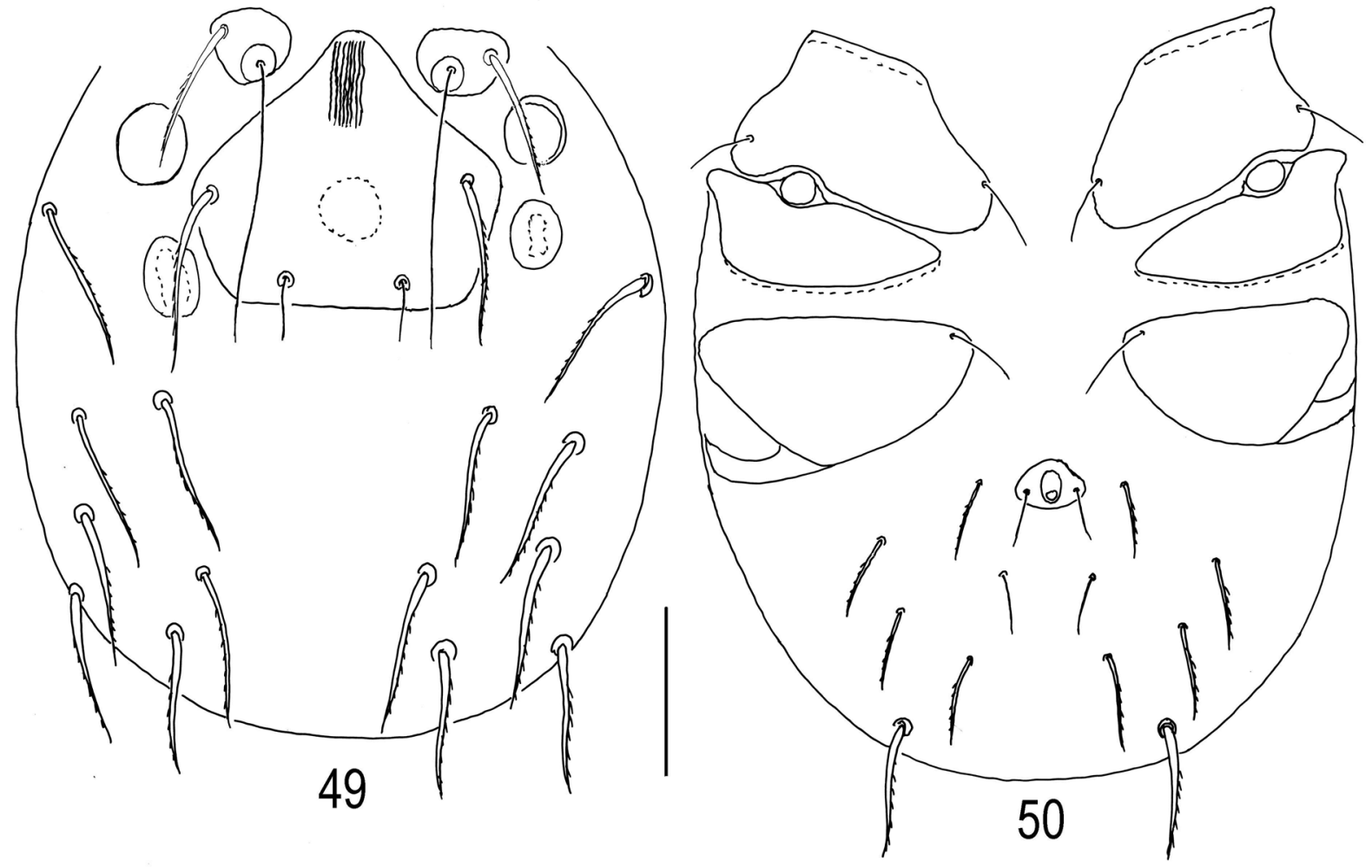

Figs. 49-50. Hydryphantes hellichi Thon, 1899, larva: 49—dorsal view; 50—ventral view. Scale bar: $50 \mu \mathrm{m}$. 


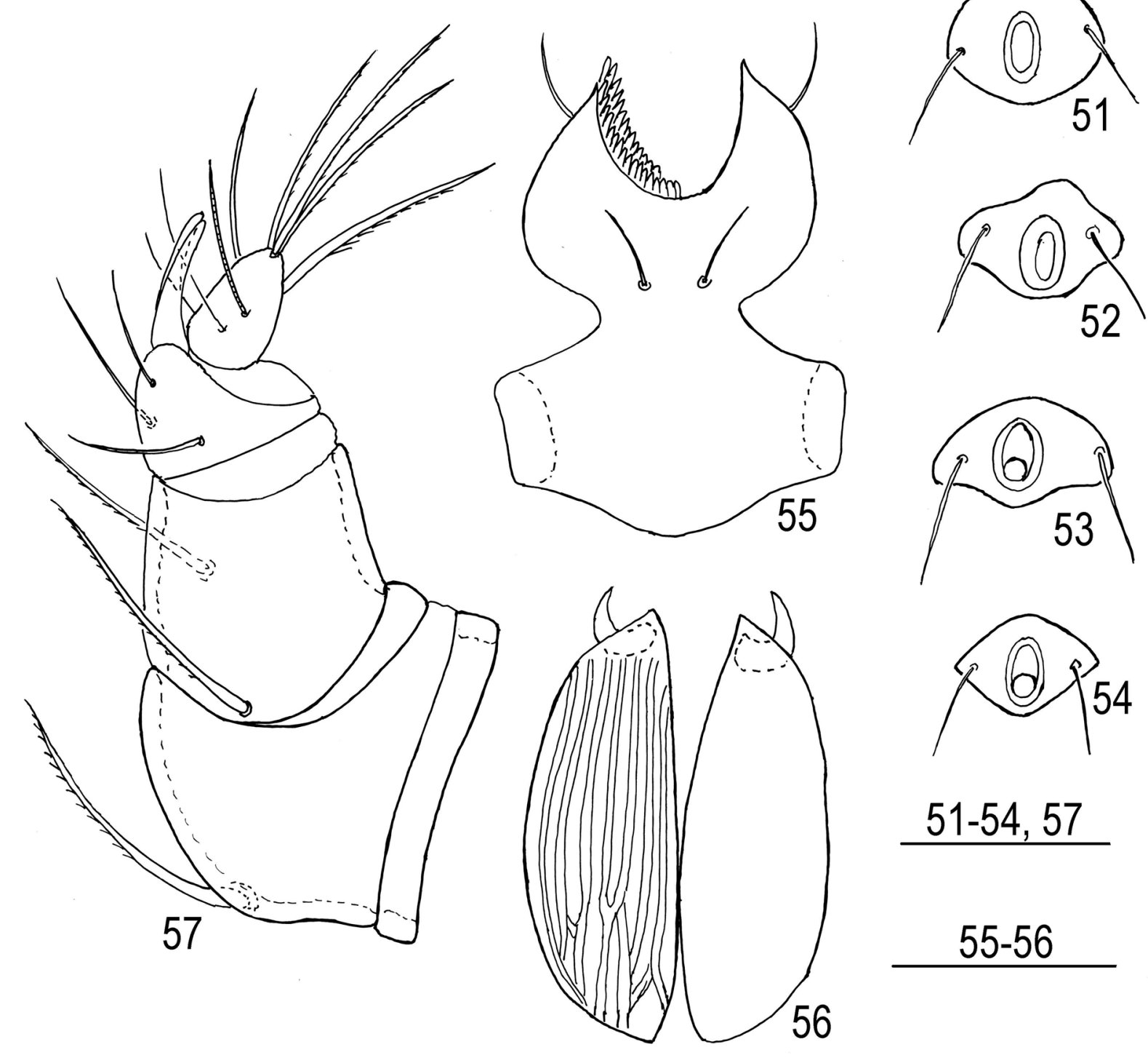

Figs. 51-57. Hydryphantes hellichi Thon, 1899, larva: 51-54-excretory pore plate; 55-capitulum, ventral view; 56 - chelicerae, dorsal view; 57-pedipalp, lateral view. Scale bars: $51-54,57=20 \mu \mathrm{m}, 55-56=50 \mu \mathrm{m}$.

Larva. Idiosoma oval (Fig. 49). Anterior pair of dorsal platelets triangular or oval, trichobothria $F p$ very long and well extending to posterior margin of dorsal plate. Posterior plate pentagonal, wider than long (L/W ratio 0.75-0.90), narrows anteriorly and widens posteriorly; median eye slightly developed (sometimes hardly visible) and situated slightly posterior to setae $V i$; Fch slightly shorter $\mathrm{Vi}$; $\mathrm{O} i$ short, distance between $\mathrm{Oi}-\mathrm{Oi}$ larger than their length. Hysterosomal setae $\mathrm{Hi}, \mathrm{He}$, Sci, Sce, Li, Le, and Si subequal.

Coxal plates II triangular, coxal plates I and III more or less trapezoidal and broadly rounded medially, all coxal setae short and subequal (Fig.
50). Urstigma oval and wider than long. Setae $S e$, $\mathrm{Ci}, \mathrm{Pi}$, and $P e$ subequal and slightly longer than both pairs of anal setae $(A i, A e)$.

Excretory pore plate small, wider than long (L/W ratio 0.57-0.64), its shape variable (Figs. 51-54). Capitulum (Fig. 55) with short, wide base, ventral setae slightly shorter than dorsal ones. Basal part of capitulum without distinct reticulations. Basal segment of chelicera (Fig. 56) with wide strips.

Pedipalps moderately long (Fig. 57): P-2 large with convex dorsal margin and single dorsal seta proximally to middle of segment; P-3 with two subequal setae (proximal and distal); P-4 with three 


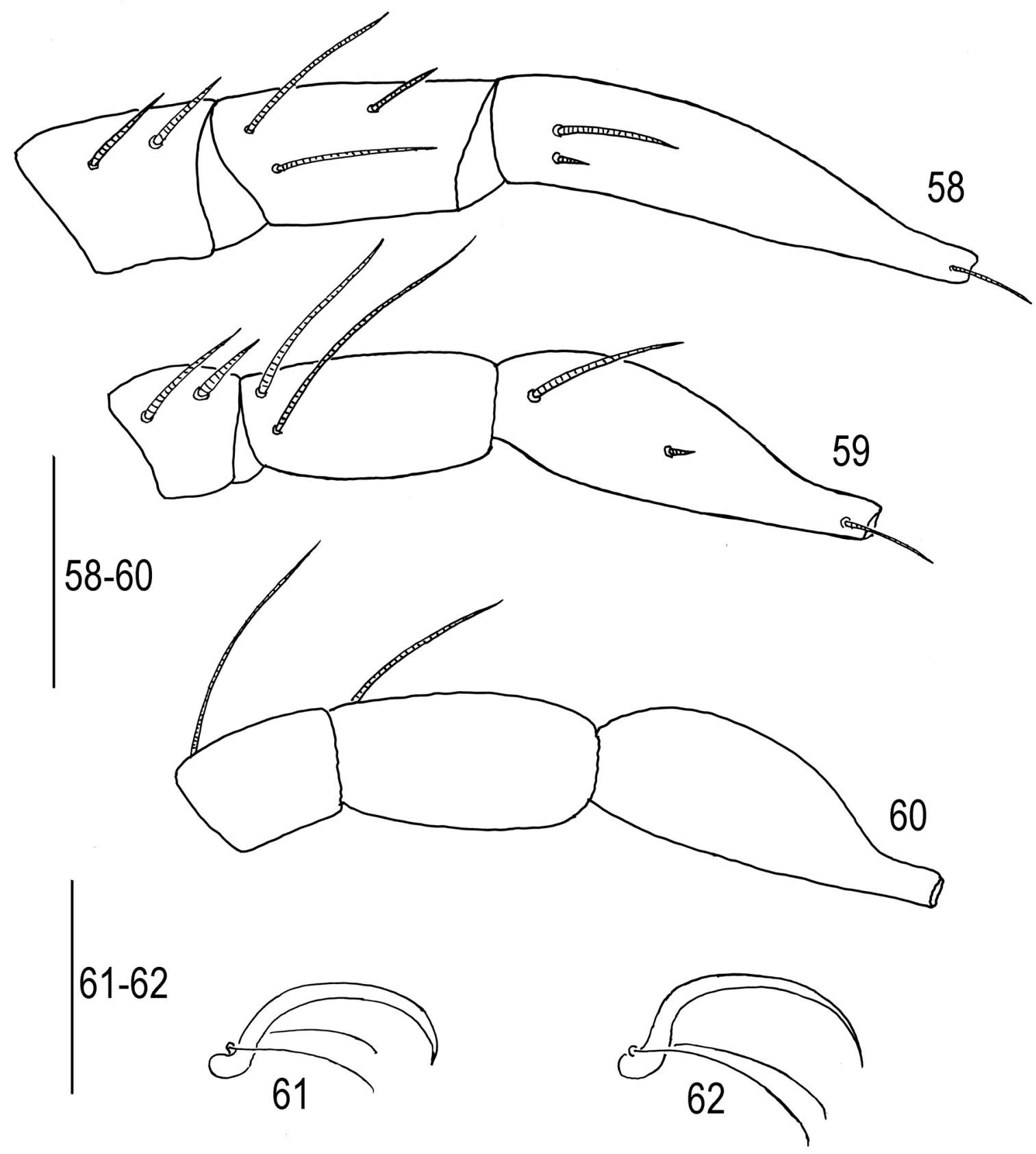

Figs. 58-62. Hydryphantes hellichi Thon, 1899, larva: 58-I-Leg-4-6; 59-II-Leg-4-6; 60-III-Leg-4-6; 61—claws of leg I; 62 - claws of leg III. Simple setae on I-III-Leg-4-6 are not shown. Scale bars: $20 \mu \mathrm{m}$.

unequal setae and large dorsodistal bifurcate claw with subequal clawlets; P-5 solenidion longer of segment.

Shape and arrangement of specialized setae on terminal legs segments as shown in Figs. 58-60. I-Leg-4 solenidion and eupathidium equal in length, I-Leg-5 with subequal solenidia, I-Leg-6 $\mathrm{de}=\mathrm{ds}$; II-Leg-4 solenidion longer than eupathidium, II-Leg-5 with unequal proximal solenidia, II-Leg-6 solenidion is proximal and eupathidium is submedial; III-Leg-4 proximal solenidion longer than III-Leg-5 solenidion. Empodium large and crescent on all tarsi, ambulacra I-II (Fig. 61) shorter than ambulacra III (Fig. 62).

Measurements, $\mathrm{n}=10$. Dorsal plate L 41-48, W 51-58; setae Fch L 25-32, setae Fp L 44-52, setae $V i$ L 32-38, setae Oi L 10-13, setae Oe, Hi, He, $\mathrm{Sci}$, Sce, $\mathrm{Li}$, Le, and $\mathrm{Si}$ L 28-32; setae $\mathrm{Ci}, \mathrm{Se}, \mathrm{Pi}$, $\mathrm{Pe}$ 16-19; setae $\mathrm{Ai}$ and $\mathrm{Ae}$ 13-15; distance between setae $\mathrm{Vi}-\mathrm{Vi}$ 40-45, distance between setae $\mathrm{Oi}-\mathrm{Oi}$ 15-23; excretory pore plate L 9-11, W 12-16; urstigma L 5-7, W 8-12; basal segments of chelicerae L 85-99, chela L 21-26; pedipalpal segments (P-1-5) L: 6-8, 26-32, 17-26, 13-19, 9-13; legs 


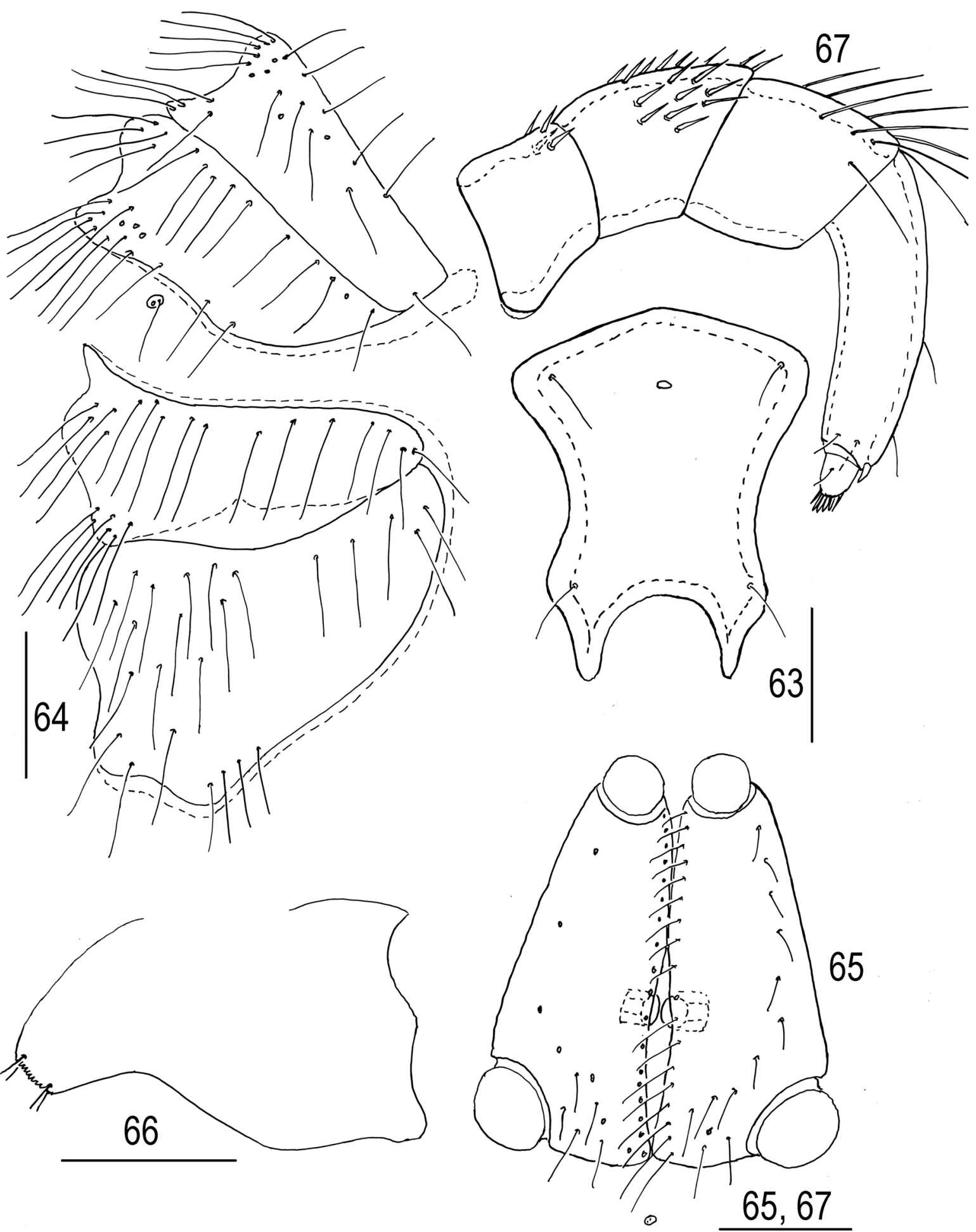

Figs. 63-67. Hydryphantes hellichi Thon, 1899, female: 63 —-frontal plate; 64 — coxal plates; 65-genital field, 66capitulum; 67-pedipalp. Scale bars: 63, 64, 66=200 $\mu \mathrm{m} ; 65,67=100 \mu \mathrm{m}$.

segments L: I-Leg-1-6: 21-26, 16-19, 13-16, 22-29, 27-35, 53-64; II-Leg-1-6: 22-25, 12-19, 10-14, 16-18, 26-32, 41-48; III-Leg-1-6: 24-30, $12-16,9-14,17-23,27-33,41-48$; de $1=6-8$, ds1-6-8; de2-20-24, ds2 $=6-10$.
Female. Integument soft, with short rounded papillae. Frontal shield (Fig. 63) elongate (L/W ratio 1.17-1.35), anterior margin convex, lateral margins concave, posterior projections rather long. Median eye small and situated almost at level of 
anterior setae. All coxal plates with numerous setae (Fig. 64).

Genital plates (Fig. 65) elongate (L/W ratio 2.0-2.5), with 20-30 pairs medial and 5-18 pairs lateral setae; anterior pair of acetabula large than second pair but slightly smaller than posterior pairs of acetabula.

Capitulum (Fig. 66) with long rostrum (base of capitulum/rostrum L ratio 2.0-2.7) and convex ventral margin.

Pedipalp compact (Fig. 67): P-1 with 3-4 dorsodistal setae; P-2 with $13-18$ setae; P-3 with 7-10 setae; P-4 slender with four thin setae and short, thick dorsodistal spine.

Number of swimming setae: II-Leg-4-5, 3-6, 16-20; III-Leg-3-5, 0-4, 13-20, 17-28; IVLeg-3-5, 3-8, 20-27, 20-26.

Measurements, female $(\mathrm{n}=7)$. Idiosoma $\mathrm{L}$ 1600-2070; dorsal plate L 535-570, W 410-465; genital flaps L 275-315, W 135-150; genital acetabula (ac. 1-ac. 3) D 50-60, 35-40, 60-75; capitulum L 400-460, rostrum L 110-125, chelicera total L 525-590, chela L 175-200; pedipalpal segments (P-1-5) L: 90-100, 175-190, 110-125, 235-255, 37-50; legs segments L: I-Leg-1-6: 110-150, 150-165, 175-215, 260-300, 310-350, 310-365; II-Leg-1-6: 125-150, 150-180, 210-250, 360-425, 410-475, 410-475; III-Leg-1-6: 125$140,160-190,225-265,375-450,425-500$,
425-475; IV-Leg-1-6: 235-265, 250-265, 350400, 500-590, 500-565, 435-500.

Remarks. The water mite Hydryphantes hellichi, for a long time was treated as a separate species (Thon 1899, Piersig 1897-1900; K.Viets 1936, 1956; Sokolow 1940; K.O. Viets 1987, etc). However Lundblad (1962) proposed synonymization with $H$. ruber, followed Di Sabatino et al. (2010). The water mite Hydryphantes hellichi is similar to $H$. ruber. However, clear differences have been found in the morphology of larvae, deutonymphs and adults of $H$. hellichi compared with the latter species (Tuzovskij 2014b), and $H$. hellichi should be treated as a separate species. The larva described by Wainstein (1980) as H. planus is the larva H. hellichi (Tuzovskij 2014c).

\section{Hydryphantes ildensis Tuzovskij, 2016}

(Figs. 68-84)

Material examined. 23 larvae reared from single female (holotype), Russia, Yaroslavl Province, Nekouz District, Ild stream near village Mar'ino, 15 June 2004, P.V. Tuzovskij. The duration of the embryonic period was 12-13 days.

Diagnosis. Larva. Distance between bases of trichobothria $O i$ larger than their length; median eye situated between setae $V i$; all dorsal hysterosomal setae subequal; basal segment of chelicera
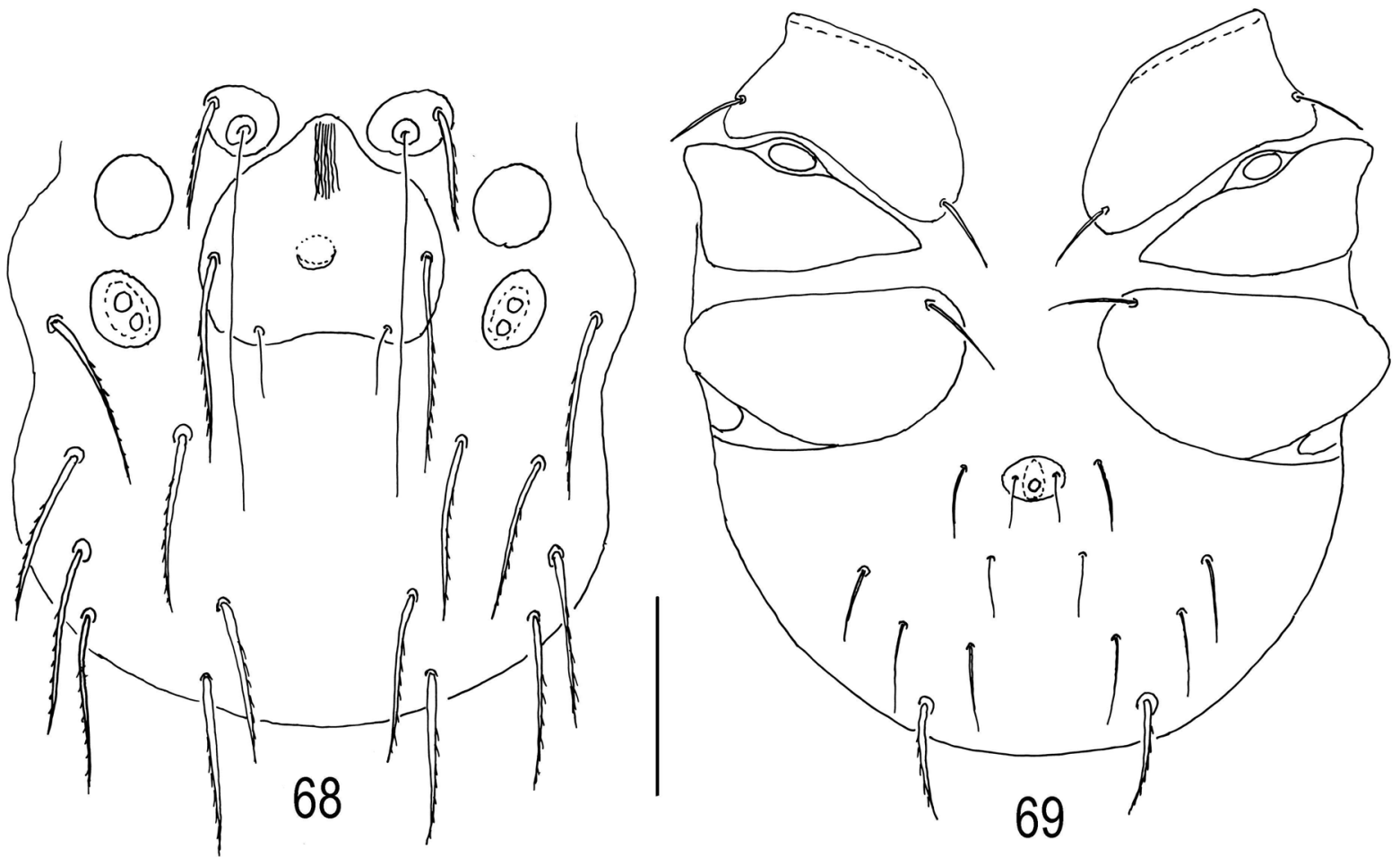

Figs. 68-69. Hydryphantes ildensis, larva: 68—dorsal view; 69-ventral view. Scale bar: $50 \mu \mathrm{m}$. 

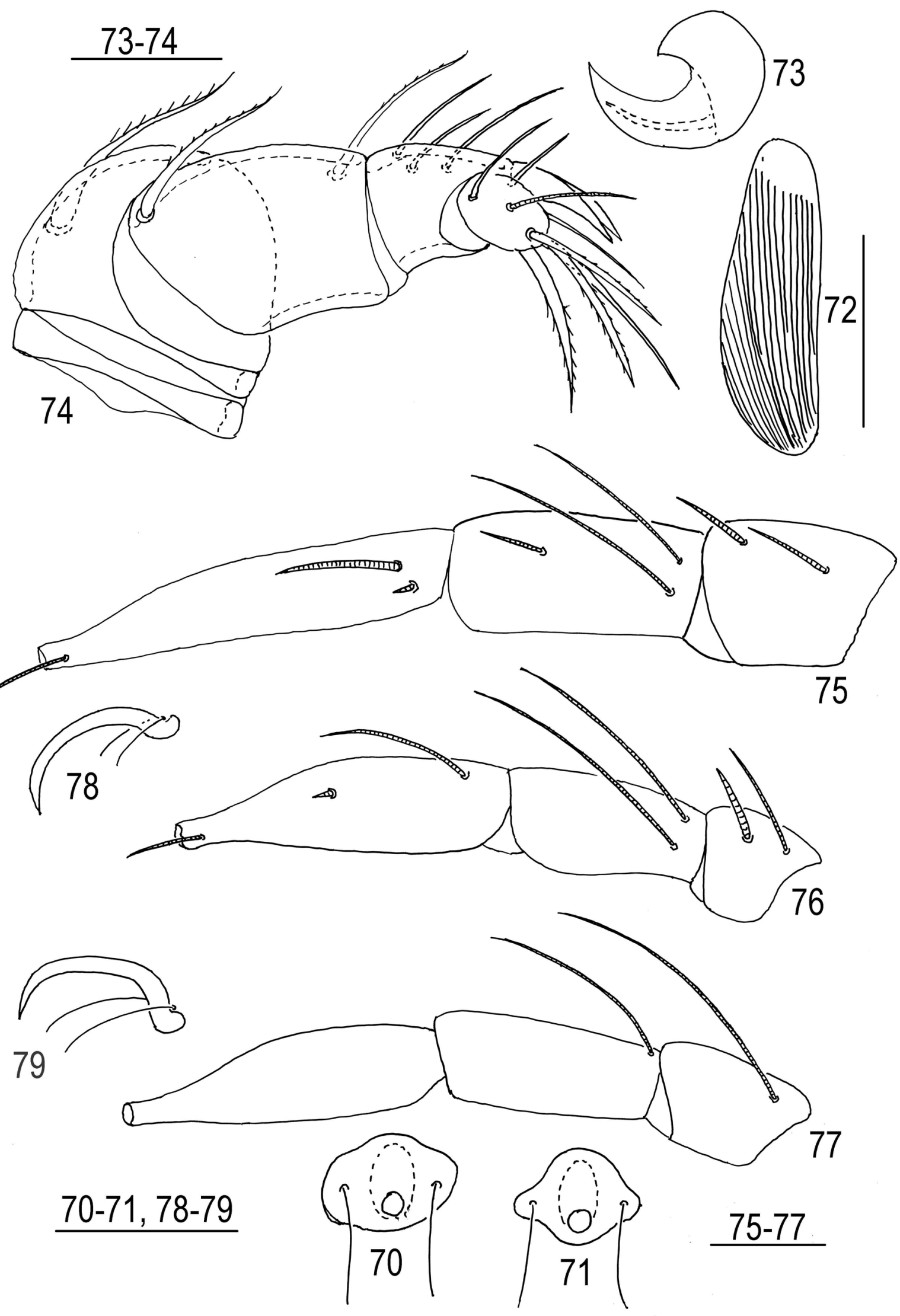

Figs. 70-79. Hydryphantes ildensis, larva: 70-71, excretory pore plate; 72-basal segment of chelicera, dorsal view; 73 - chela, lateral view; 74 - pedipalp, lateral view; 75-I-Leg-4-6; 76-II-Leg-4-6; 77-III-Leg-4-6; 78 — claws of leg I; $79-$ claws of leg III. Simple setae on I-III-Leg-4-6 are not shown. Scale bars: $70-71,73-79=20 \mu \mathrm{m}, 72=50 \mu \mathrm{m}$. 

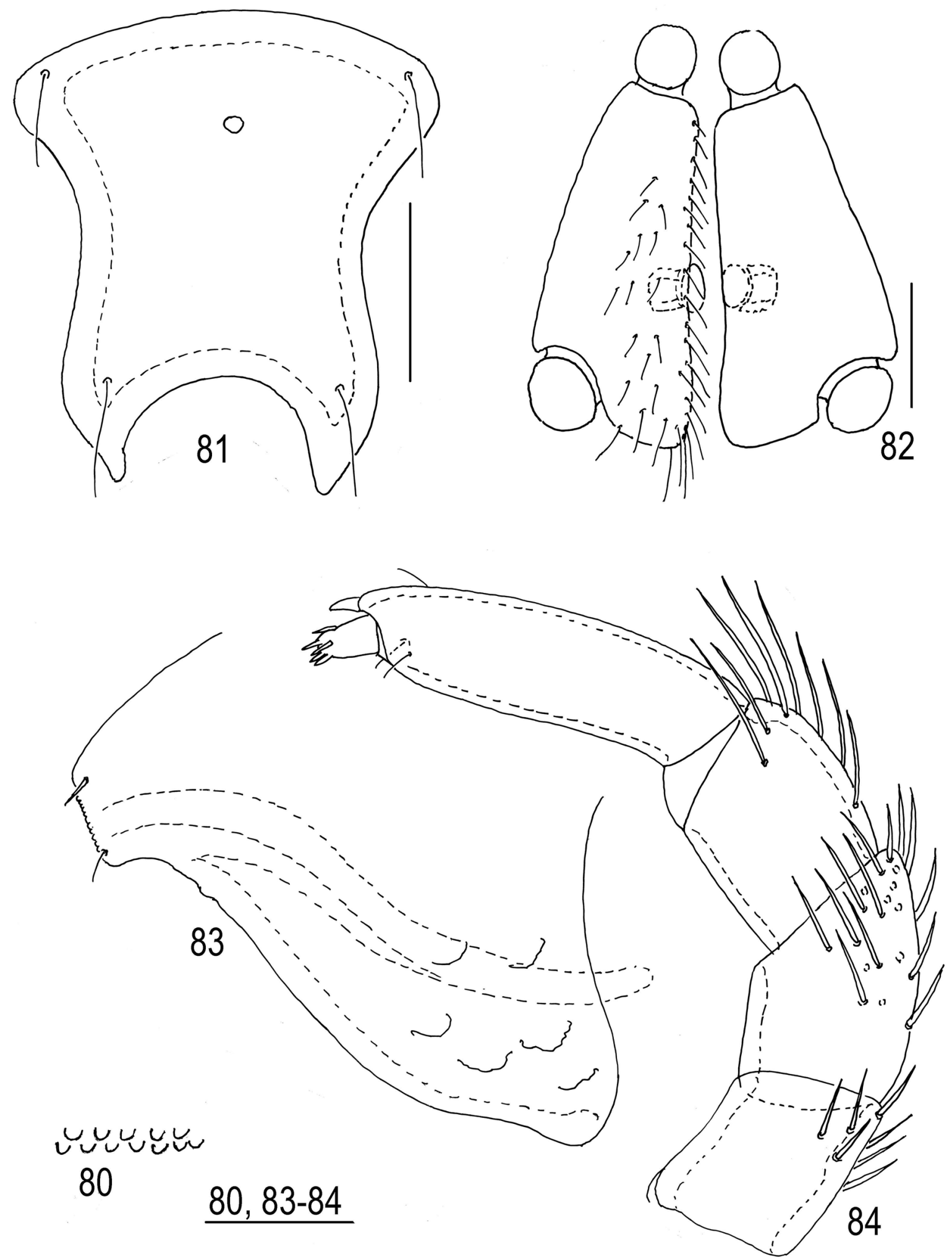

Figs. 80- 84. Hydryphantes ildensis, female: 80 -fragment of integument; 81-frontal plate; 82-genital field; 83capitulum; $84-$ pedipalp. Scale bars: $80,82-84=100 \mu \mathrm{m}, 81=200 \mu \mathrm{m}$.

with narrow strips; posterior margin of coxal plate II slightly convex; excretory pore plate as long as wide or wider than long; P-4 dorsodistal claw with two subequal clawlets; I-Leg-4 solenidion and eupathidium subequal in length, II-Leg-4 solenidion 1.5 times longer than eupathidium, I/II-Leg-5 with unequal solenidia; III-Leg-4 solenidion longer than III-Leg-4 solenidion, I-Leg-6 $d e<d s$. 
Description. Larva. Anterior pair of platelets small, more or less triangular; posterior plate relatively large, anteriorly narrow, posteriorly widening; median eye weakly developed (often hardly visible) and situated between setae $V i$ (Fig. 68). Both pairs of trichobothria thin, $F p$ very long, $O i$ short. Distance between bases of trichobothria $O i-O i$ larger than their length. Simple proterosomal setae (Fch and $V i$ ) thick, but Fch shorter than Vi. Other dorsal setae (Oe, Hi, He, Sci, Sce, $\mathrm{Li}$, and $\mathrm{Le}$ ) thick and subequal.

Coxal plates II triangular without setae, coxal plates I and III more or less trapezoidal and rounded medially (Fig. 69); all coxal setae relatively short and subequal. Urstigma oval, wider than long. Setae $S i$ longer and thicker than other ventral idiosomal setae. Setae $\mathrm{Se}, \mathrm{Ci}, \mathrm{Pi}$, and $\mathrm{Pe}$ subequal and slightly longer and thicker than both pairs of anal setae.

Excretory pore plate small, usually as long as wide or slightly wider than long (Figs. 70-71), excretory pore situated near posterior plate margin. Bases of setae $A i$ situated anterior to excretory pore.

Chelicera (Fig. 72) with large basal segment and small chela (Fig. 73). Basal segment with rather numerous thin strips.

Pedipalps stout (Fig. 74): P-2 large with convex dorsal margin and single dorsoproximal seta; P-3 long, with two subequal setae (proximal and distal); P-4 with three thin unequal setae, dorsodistal claw large, distally bifurcate, with subequal clawlets; P-5 solenidion longer of segment.

Shape and arrangement of specialized setae on terminal legs segments as shown in Figs. 75-77. I-Leg-4 solenidion and eupathidium subequal, ILeg-5 proximal solenidia unequal; II-Leg-5 proximal solenidia subequal; I-Leg-6 $d e$ shorter $d s$; III-Leg-4 proximal solenidion longer than III-Leg-5 proximal solenidion. Lateral claws shorter and thinner than strong empodial claw (Figs. 78-79).

Measurements, $\mathrm{n}=10$. Dorsal plate L 43-49, W 43-47; setae Fch L 27-31, setae Fp L 70-75, setae $V i$ L 37-44, setae $O i$ L 11-13, distance between setae $\mathrm{Vi}-\mathrm{Vi}$ 36-38, distance between setae $\mathrm{Oi}-\mathrm{Oi}$ 16-19; setae $\mathrm{Oe}, \mathrm{Hi}, \mathrm{He}, \mathrm{Sci}, \mathrm{Li}, \mathrm{Le}$, and $\mathrm{Si} \mathrm{L} 32-38$, setae $\mathrm{Si}$ L 25-29; setae $\mathrm{Ci}$, Se, $P$, and $P e$ 16-19; setae $A i$ and $A e$ 9-12; excretory pore plate L 10-12, W 11-13; urstigma L 6-8, W 9-11; basal segments of chelicerae L 68-76, chela L 17-19; pedipalpal segments (P-1-5) L: 6-7, 27-28, 26-28, 13-16, 11-12; leg segments L: I-Leg-1-6: 22-25, 20-24, 15-18, 25-28, 33-37, 60-64; II-Leg-1-6: 25-27, 18-23, 12-14, 16-19, 30-32, 50-54; III-Leg-1-6: 25-28, 16-20, 12-15, 20-23, 31-34, 47-50.
Female. Integument with short rounded papillae (Fig. 80). Frontal plate (Fig. 81) compact with convex anterior margin, posterior margin concave, posterior projections relatively short, median eye situated posterior to anterior setae. Genital flap elongate (L/W ratio 2.1), with 20-23 medial and 12-17 lateral setae (Fig. 82).

Capitulum (Fig. 83) with short rostrum, capitular base with convex ventral margin.

Pedipalp slender (Fig. 84): P-1 with 7-8 short dorsodistal setae; P-2 with 18-21 setae;

P-3 with 8 setae; P-4 with short dorsodistal spine and 3 thin distal setae.

Measurements $(\mathrm{n}=1)$. Idiosoma L 1750; frontal plate L 485, W 435; coxal plates I+II L 335, W 435; coxal plates III+IV L 560, W 450; genital flap L 260, W 125; genital acetabula (ac.1-ac.3) D 50, 37, 62; capitulum L 300; rostrum L 43; chelicera L 435, chela L 135; pedipalpal segments (P-1-5) L: 87, 137, 100, 200, 50; leg segments L: ILeg-1-6: 110, 125, 150, 260, 285, 260; II-Leg-1-6: 110, 135, 195, 335, 375, 375; III-Leg-1-6: 125, 150, 210, 350, 395, 360; IV-Leg-1-6: 225, 225, $300,460,450,385$.

Remarks. The female of the new water mite is similar to the female Hydryphantes nonundulatus, and the larva is similar to the larva of $H$. planus (Tuzovskij 2016a). The latter species differs at the larval stage in: (1) P-3 short, $\mathrm{L}=16-19 \mu \mathrm{m}$; (2) P-5 solenidion shorter than segment; (3) I-Leg-5 solenidia subequal; (4) $F p$ comparatively short $\mathrm{L}=55-65 \mu \mathrm{m}$.

\section{Hydryphantes nonundulatus Thon, 1899}

(Figs. 85-102)

Material examined. Larvae $(n=58)$ were reared from six females in laboratory conditions, two female 28 May 2000, one female 4 July 2001, two females 27 May 2002 and one female 17 June 2004. The duration of the embryonic period was 11-14 days.

Diagnosis. Larva. Posterior plate longer than wide, distance between bases of trichobothria $\mathrm{Oi}$ Oi shorter than their length; median eye rather large and situated between setae $\mathrm{Vi}$; all dorsal hysterosomal setae subequal; basal segment of chelicera with numerous thin strips; excretory pore plate as long as wide or slightly wider than long, bases of setae $A i$ situated near middle of excretory pore plate; P-4 dorsodistal claw with two slightly unequal clawlets; P-5 solenidion longer than segment; I/II-Leg-4 solenidion 2.0-2.5 times longer than 

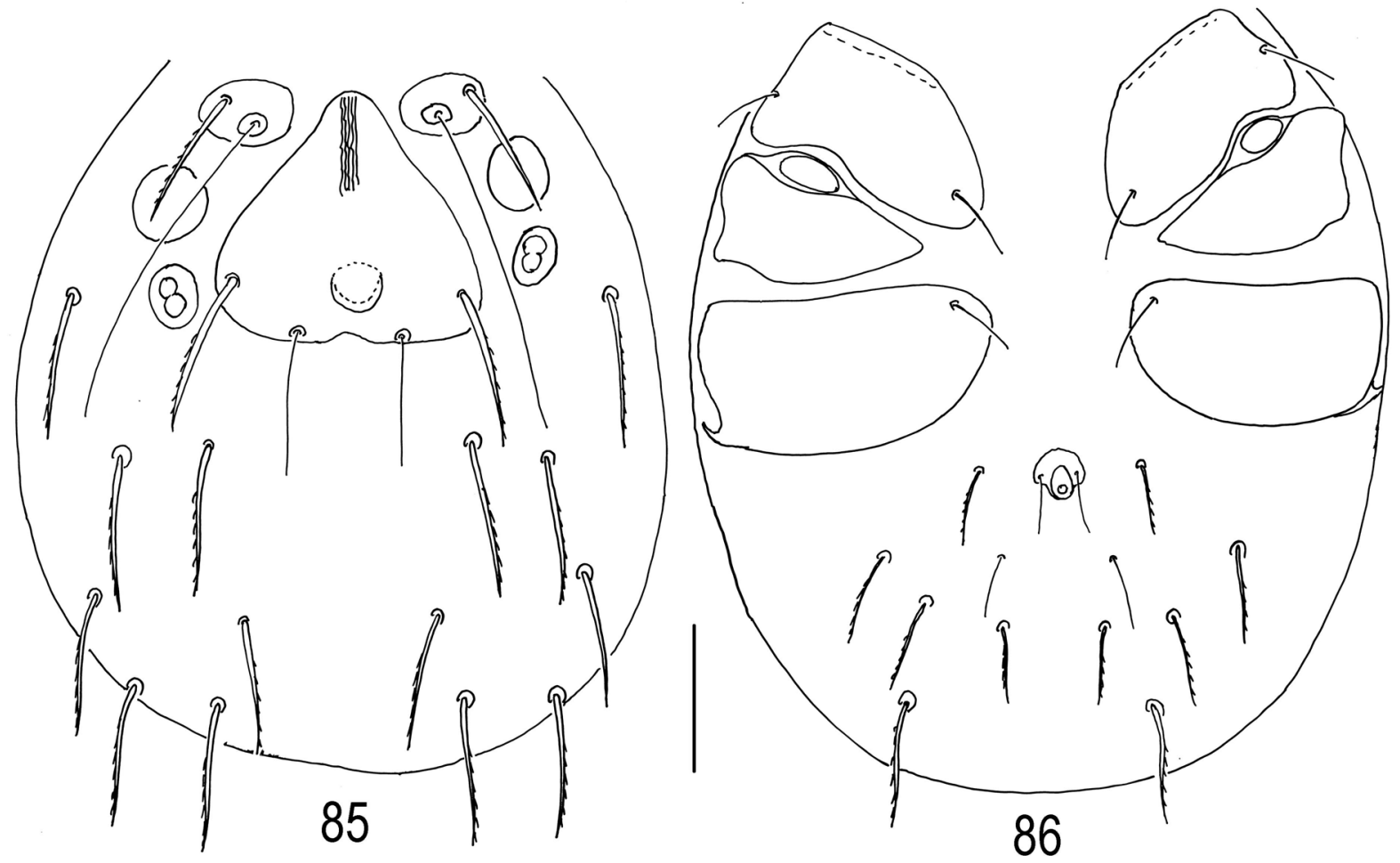

Figs. 85-86.Hydryphantes nonundulatus Thon, 1899, larva: 85-dorsal view; 86-ventral view. Scale bar: $50 \mu \mathrm{m}$.

eupathidium; I/II-Leg-5 with unequal solenidia; I-Leg-6 $d e<d s$.

Larva. Anterior pair of dorsal platelets triangular or oval, trichobothria $F p$ long and extending to posterior margin of dorsal plate (Fig. 85). Posterior plate a little longer than wide (L/W ratio $0.81-0.95$ ), narrows anteriorly and widens posteriorly; median eye rather large and situated between setae $\mathrm{Vi}$; distance between $\mathrm{Oi}-\mathrm{Oi}$ shorter than their length. Fch slightly shorter $V i$. Other dorsal setae (Oe, $\mathrm{Hi}, \mathrm{He}$, Sci, Sce, $\mathrm{Li}$, and $\mathrm{Le}$ ) thick and nearly subequal. Anterior lateral eyes circular, posterior lateral eyes elongate.

Coxal plates II triangular with convex posterior margin, coxal plates I and III more or less trapezoidal and broadly rounded medially, all coxal setae short and subequal (Fig. 86). Urstigma oval wider than long, moderately in size. Setae $S i$ slightly longer and thicker than other ventral idiosomal setae. Setae $\mathrm{Se}, \mathrm{Ci}, \mathrm{Pi}$, and $\mathrm{Pe}$ subequal and slightly longer and thicker than both pairs of anal setae $(A i, A e)$. Excretory pore plate (Figs. 87-88) as long as or slightly wider than long (L/W ratio $0.70-1.00$ ), excretory pore situated near posterior margin of plate. Bases of setae Ae situated near middle of excretory pore plate.

Capitulum (Fig. 89) with short, wide base, ventral setae longer than dorsal ones. Posterior portion of basal part of capitulum with distinct reticulations. Basal segment of chelicera (Fig. 90) with numerous thin strips, chela small and massive (Fig. 91)

Pedipalps moderately developed (Fig. 92): P-2 large with convex dorsal margin and single dorsoproximal seta; P-3 with two unequal setae (proximal and distal); P-4 with three unequal thin setae and large dorsodistal claw with unequal clawlets; P-5 solenidion longer of segment.

Shape and arrangement of specialized setae on terminal legs segments as shown in Figs. 93-95. I/ II-Leg-4 solenidion shorter than segment but 2.0-2.5 times longer than eupathidium; I/II-Leg-5 with two unequal proximal solenidia; I-Leg-6 de $<$ ds; II-Leg- 6 solenidion is proximal and eupathidium is submedial; III-Leg-4 proximal solenidion slightly shorter than III-Leg-5 solenidion. I/II-Leg-6 with relatively long distal acanthoid setae. Empodium large and crescent on all tarsi, ambulacra short and thin (Fig. 96).

Measurements, $\mathrm{n}=10$. Dorsal plate L 41-44, $\mathrm{W}$ 48-54; setae Fch L 28-32, setae Fp L 60-67, setae $V i$ L 35-38, setae $\mathrm{O} i \mathrm{~L}$ 27-35, setae $\mathrm{Oe}, \mathrm{Hi}, \mathrm{He}$, $\mathrm{Sci}$, Sce, Li, Le, and Si L 28-32; setae Ci, Se, Pi, $P e$ 16-19; setae $A i$ and $A e$ 10-13; distance between setae $\mathrm{Vi}-\mathrm{Vi}$ 38-44, distance between setae $\mathrm{Oi}-\mathrm{Oi}$ 19-27; excretory pore plate L 8-11, W 10-13; 


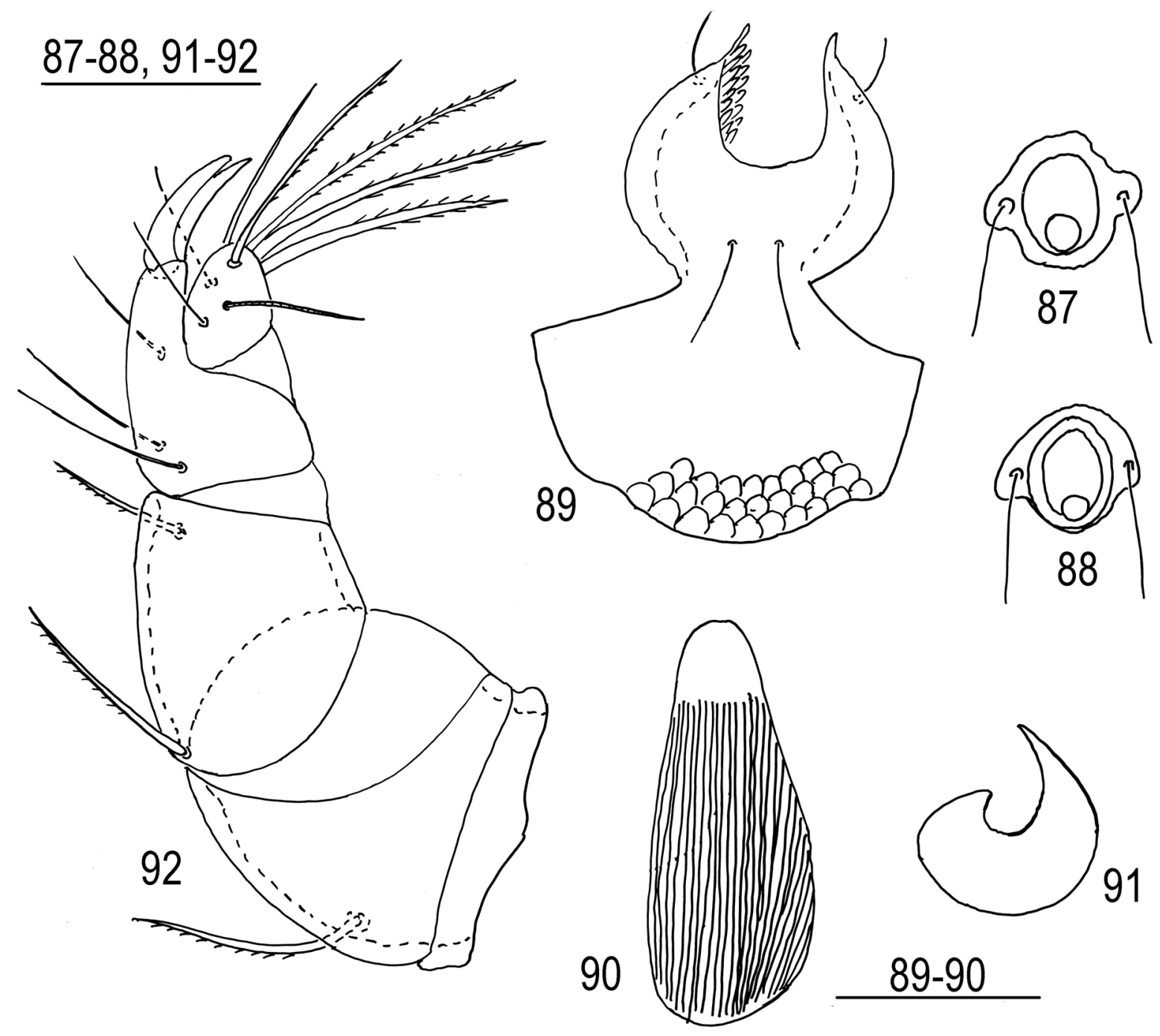

Figs. 87-92. Hydryphantes nonundulatus Thon, 1899, larva: 87-88-excretory pore plate; 89-capitulum, ventral view; 90 - basal segment of chelicera, dorsal view; 91 — chela; 92 - pedipalp, lateral view. Scale bars: 87-88, 91-92=20 $\mu \mathrm{m}, 89-90=50 \mu \mathrm{m}$.

urstigma L 9-12, W 12-14; basal segments of chelicerae L 77-85, chela L 20-21; pedipalpal segments (P-1-5) L: 6-7, 22-30, 25-32, 15-19, 9-11; legs segments L: I-Leg-1-6: 22-28, 13-23, 16-19, 26-31, 33-39, 63-69; II-Leg-1-6: 22-26, 10-20, 13-16, 18-21, 35-37, 53-60; III-Leg-1-6: 22-28, 16-22, 12-16, 22-25, 37-42, 50-55.

Female. Frontal shield (Fig. 97) subquadrate (L/W ratio 0.95-1.13), anteriolateral extensions wider than posteriolateral extensions, anterior margin obtuse-angled or slightly convex, posterior margin convex, posterior projections short, their length equal to $1 / 4-1 / 5$ length of basal portion of plate. Median eye small and situated distinctly posterior at level of anterior setae.

All coxal plates with rather numerous setae (Fig. 98). Acetabular plates elongate (L/W ratio
2.0-2.2), with $17-23$ pairs setae on each side (Fig. 99).

Capitulum (Fig. 100) with relatively short rostrum (base of capitulum/rostrum L 4.2-5.5) and slightly convex ventral margin. Chelicera (Fig. 101) rather slender, basal segment with large dorsal hump near middle.

Pedipalp compact (Fig. 102): P-1 with 3-5 dorsodistal setae; P-2 with 6-13 setae; P-3 height longer than length of segment, with 4 setae; P-4 tapering distally, shorter than $\mathrm{P}-2+\mathrm{P}-3$, with three thin setae and short, thick dorsodistal spine.

Measurements, female $(\mathrm{n}=8)$. Idiosoma $\mathrm{L}$ 1500-1750; dorsal plate L 410-475, W 425-465; genital flap L 260-290, W 110-125; genital acetabula (ac.1-ac.3) D 50-63, 37-42, 65-75; capitulum L 330-340, rostrum L 60-75, chelicera L 


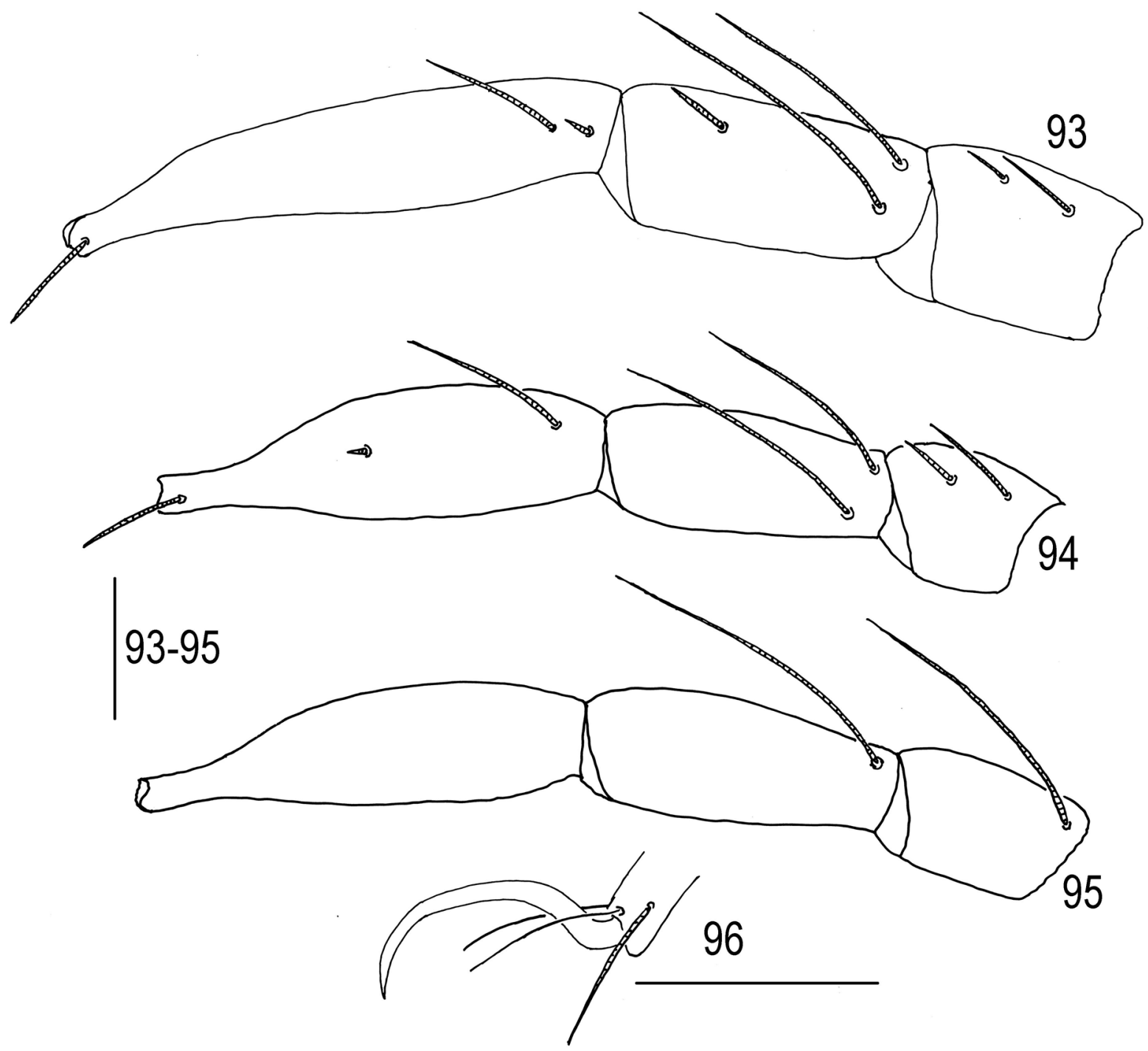

Figs. 93-96. Hydryphantes nonundulatus Thon, 1899, larva: 93-I-Leg-4-6; 94-II-Leg-4-6; 95-III-Leg-4-6; 96claws of leg I; 47, claws of leg III. Simple setae on I-III-Leg-4-6 are not shown. Scale bars: $20 \mu \mathrm{m}$.

325-350, cheliceral stylet L 175-190; pedipalpal segments (P-1-5) L: 75-85, 125-150, 75-88, 185-200, 25-30; legs segments L: I-Leg-1-6: $100-125,110-140,150-165,225-265,250-290$, 260-290; II-Leg-1-6: 110-140, 135-150, 175-215, 300-350, 360-420, 385-425; III-Leg-1-6: 100$140,135-150,185-215,310-365,385-440$, 385-425; IV-Leg-1-6: 200-225, 200-215, 275$315,450-515,450-515,375-425$.

Remarks. There is no uniform opinions on the taxonomic status of the water mite Hydryphantes nonundulatus. Originally $H$. nonundulatus was described as a subspecies of $H$. bayeri Pisařovic, 1896 (Viets 1919), but some researchers (Stiller 1960, Szalay 1964) treated it as a subspecies of $H$. ruber (Geer, 1778), and Láska (1964) proposed $H$. nonundulatus as a separate species. However,
Lundblad (1962) proposed to synonymize this species with $H$. planus, followed by Di Sabatino et al. (2009, 2010). Biesiadka and Cichocka (1990) gave a brief description of the morphology of the larva $H$. nonundulatus. The deutonymphs of this species has been previously unknown. The water mite H. nonundulatus is similar to H. planus. However, clear differences have been found in the morphology of larvae, deutonymphs and adults of $H$. nonundulatus compared with the latter species (Tuzovskij 2015a), and H. nonundulatus should be treated as a separate species.

\section{Hydryphantes octoporus Koenike, 1896}

(Figs. 103-119)

Material examined. 43 larvae were reared from five females (Samara Province), and 13 larvae 


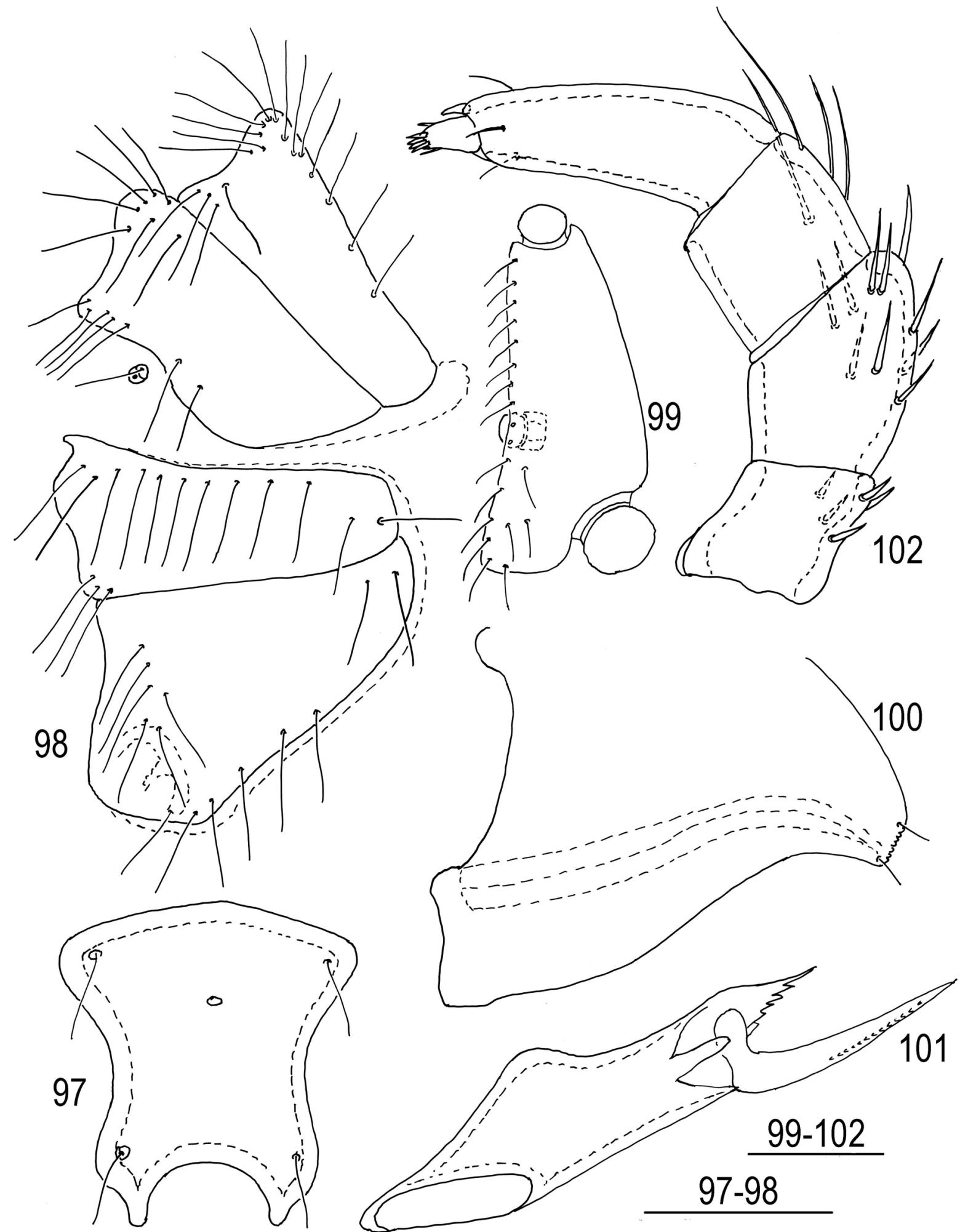

Figs. 97-102. Hydryphantes nonundulatus Thon, 1899, female: 97-frontal plate; 98—coxal plates; 99—genital plate and acetabula; 100 — capitulum; 101 —chelicera; 102 — pedipalp. Scale bars: 97-98=200 $\mu \mathrm{m}$; 99-102=100 $\mu \mathrm{m}$.

from two females (Yaroslavl Province). The duration of the embryonic period was 12-15 days.

Diagnosis. Larva. Distance between bases of trichobothria $\mathrm{Oi}$ larger than their length, setae Fch shorter than Vi, median eye situated between setae
Vi; all dorsal hysterosomal setae subequal; basal segment of chelicera with numerous strips; excretory pore plate as long as or slightly wider than long; urstigma oval; posterior margin of coxal plate II straight; P-4 dorsodistal claw with two subequal 

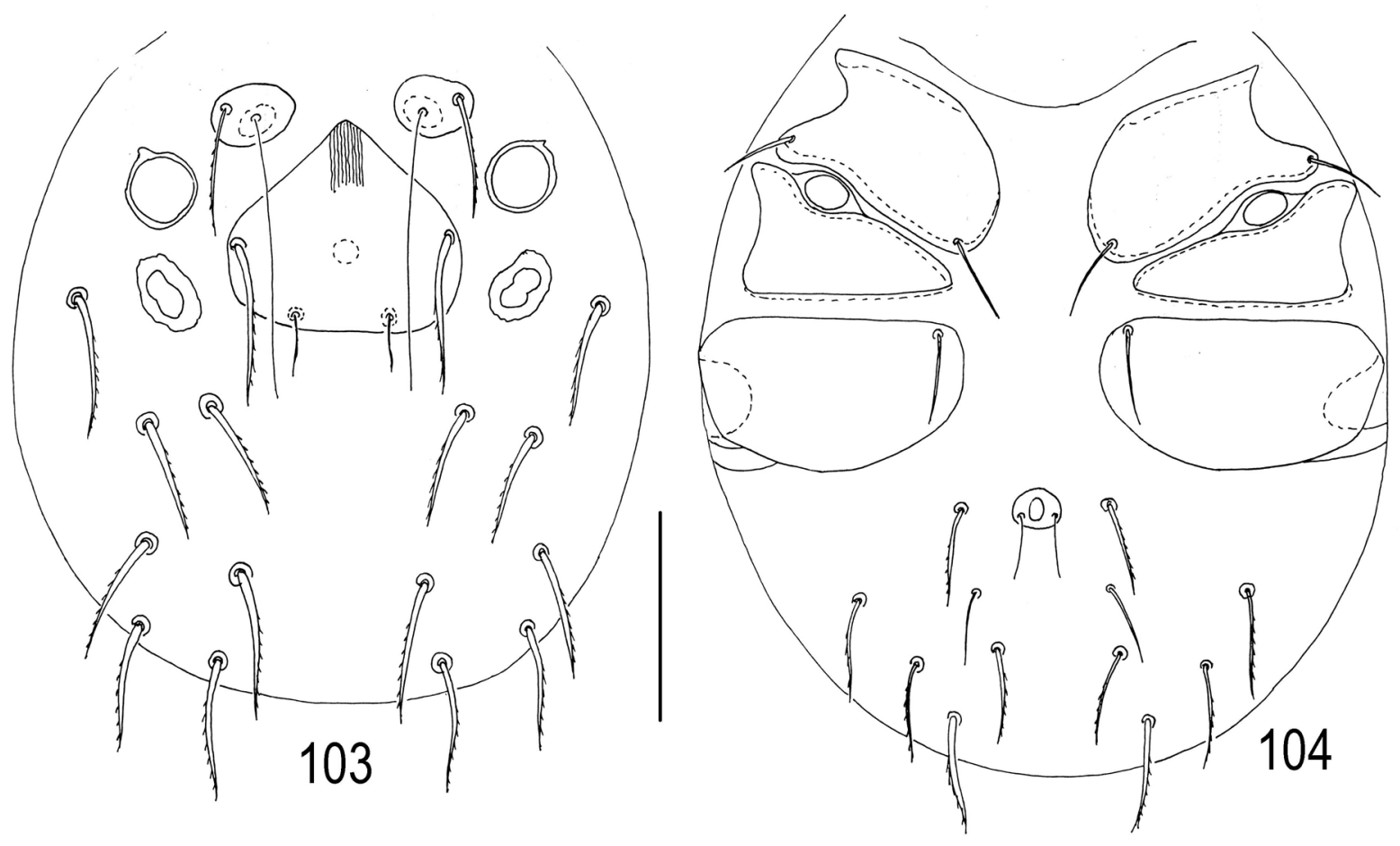

Figs. 103-104. Hydryphantes octoporus Koenike, 1896, larva: 103_dorsal view; 104_ventral view. Scale bar: $50 \mu \mathrm{m}$.

clawlets; P-5 solenidion longer of segment; I/IILeg-4 solenidion 1.5-2.0 times longer than eupathidium, I/II-Leg-5 with subequal solenidia; ILeg-6 $d e>d s$.

Larva. Anterior pair of platelets oval or triangular, posterior plate narrows anteriorly and widens posteriorly; median eye weakly developed and situated between setae Vi (Fig. 103). Both pairs of trichobothria thin, $F p$ very long, $O i$ short. Distance between bases of trichobothria $\mathrm{Oi}$ larger than their length. Simple proterosomal setae ( $F$ ch and $V i)$ thick, but $F c h$ shorter than Vi. Other dorsal setae (Oe, $\mathrm{Hi}, \mathrm{He}, \mathrm{Sci}$, Sce, $\mathrm{Li}$, and $\mathrm{Le}$ ) thick and subequal in length. Anterior lateral eyes large circular, posterior lateral eyes elongate.

Coxal plates II triangular, with straight posterior margin; coxal plates I and III more or less trapezoidal and rounded medially (Fig. 104); coxal plate I with two setae (medial and lateral), coxal plate III with single anteromedial setae. All coxal setae relatively short and subequal. Urstigma rather large and situated on anterior edge of coxal plate II near its middle. Setae $S i$ thicker and longer than other ventral idiosomal setae. Setae $\mathrm{Se}, \mathrm{Ci}, \mathrm{Pi}$, and $P e$ subequal and slightly longer and thicker than both pairs of anal setae. Excretory pore plate small, its shape variable (Figs. 105-108), excretory pore comparatively large; bases of setae $A i$ situated in posterior part of excretory pore plate.
Basal segment of chelicera with numerous strips (Fig. 109).

Pedipalps stout (Fig. 110): P-2 large with convex dorsal margin and a single dorsal setae near middle of segment; P-3 with two unequal setae (long proximal and short distal); P-4 with three thin subequal setae and large claw with subequal clawlets; P-5 solenidion longer of segment.

Shape and arrangement of specialized setae on terminal legs segments as shown in Figs. 111-113. I/II-Leg-4 solenidion 2.0-2.5 times longer than eupathidium, I/II-Leg-5 with two proximal subequal solenidia; I-Leg- 6 de longer than $d s$; II-Leg-6 solenidion in proximal, eupathidium in submedial position. Claws of leg III (Fig. 115) slightly larger than claws of legs I and II (Fig. 114). Lateral claws shorter and thinner than the strong empodial claw.

Measurements, $\mathrm{n}=10$. Dorsal plate L 48-55, W 48-58; setae Fch L 17-26, setae Fp L 52-61, setae $V i$ L 26-32, setae Oi L 6-9, setae Oe, Hi, He, Sci, $S c e, L i$, and Le L 29-33; setae $S i$ L 25-27, setae Ci, $P i$, and $P e$ L 15-17; setae $A i$ and $A e$ L 11-13; distance between setae $V i-V i 32-35$, distance between setae $O i-O i$ 22-26; excretory pore plate L 9-11, W 10-16; basal segments of chelicera L 65-80, chela L 16-17; pedipalpal segments (P-1-5) L: 5-7, 25-32, 22-29, 12-17, 6-10; legs segments L: ILeg-1-6: 22-26, 16-19, 16-20, 25-29, 32-36, 58-67; II-Leg-1-6: 22-26, 16-19, 10-13, 16-19, 


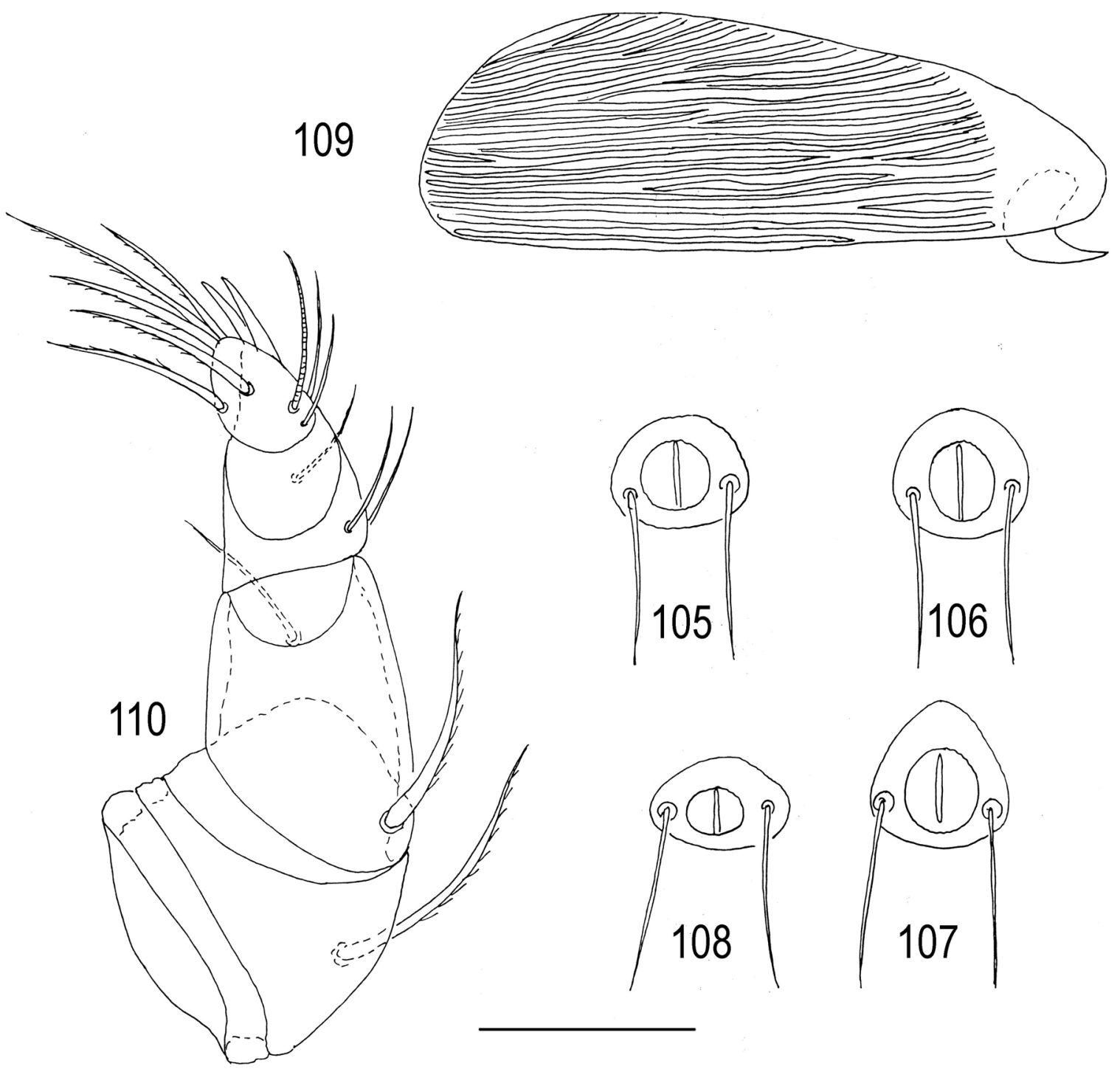

Figs. 105-110. Hydryphantes octoporus Koenike, 1896, larva: 105-108-excretory pore plate; 109-basal segment of chelicera, dorsal view; 110_-pedipalp, lateral view. Scale bar: $20 \mu \mathrm{m}$.

28-32, 48-52; III-Leg-1-6: 25-29, 16-22, 12-16, 19-23, 32-36, 44-48.

Female. Integument soft with rounded papillae (Fig. 116). Frontal plate (Fig. 117) with a bluntly pointed medioanterior protrusion and long posterior projecrions, median eye small and situated slightly posterior to anterior pair of setae.

Capitulum (Fig. 118) with equally S-shaped ventral margin and short rostrum (capitulum/rostrum L 7.0-9.5).

Pedipalp (Fig. 119) robust: P-1 with two to three dorsodistal setae; P-2 with 7-10 setae; P-3 shorter than high, with three to seven setae; P-4 rather slender, with three thin distal unequal setae and a short, thick dorsodistal spine.
Genital field with four to six acetabula and 18-23 thin setae on each side (Figs. 120-122).

Measurements, female $(\mathrm{n}=10)$. Idiosoma L 1100-1900; dorsal plate L 310-415, W 275-415; genital flap L 200-250, W 100-125; genital acetabula (ac.1-ac.2-ac.3) D 25-30, 18-25, 30-40; capitulum L 250-315, rostrum L 25-40, chelicera L 250-290, chela L 125-140; pedipalpal segments (P-1-5) L: 55-75, 100-115, 62-75, 130-165, 25-30; legs segments L: I-Leg-1-6: 65-100, 85$115,100-125,150-200,175-225,175-225$; IILeg-1-6: 75-90, 85-125, 125-165, 210-275, 250-315, 250-300; III-Leg-1-6: 85-115, 100-125, 125-165, 210-290, 260-340, 235-290; IVLeg-1-6: 150-200, 135-170, 170-250, 310-415, $325-415,260-315$. 


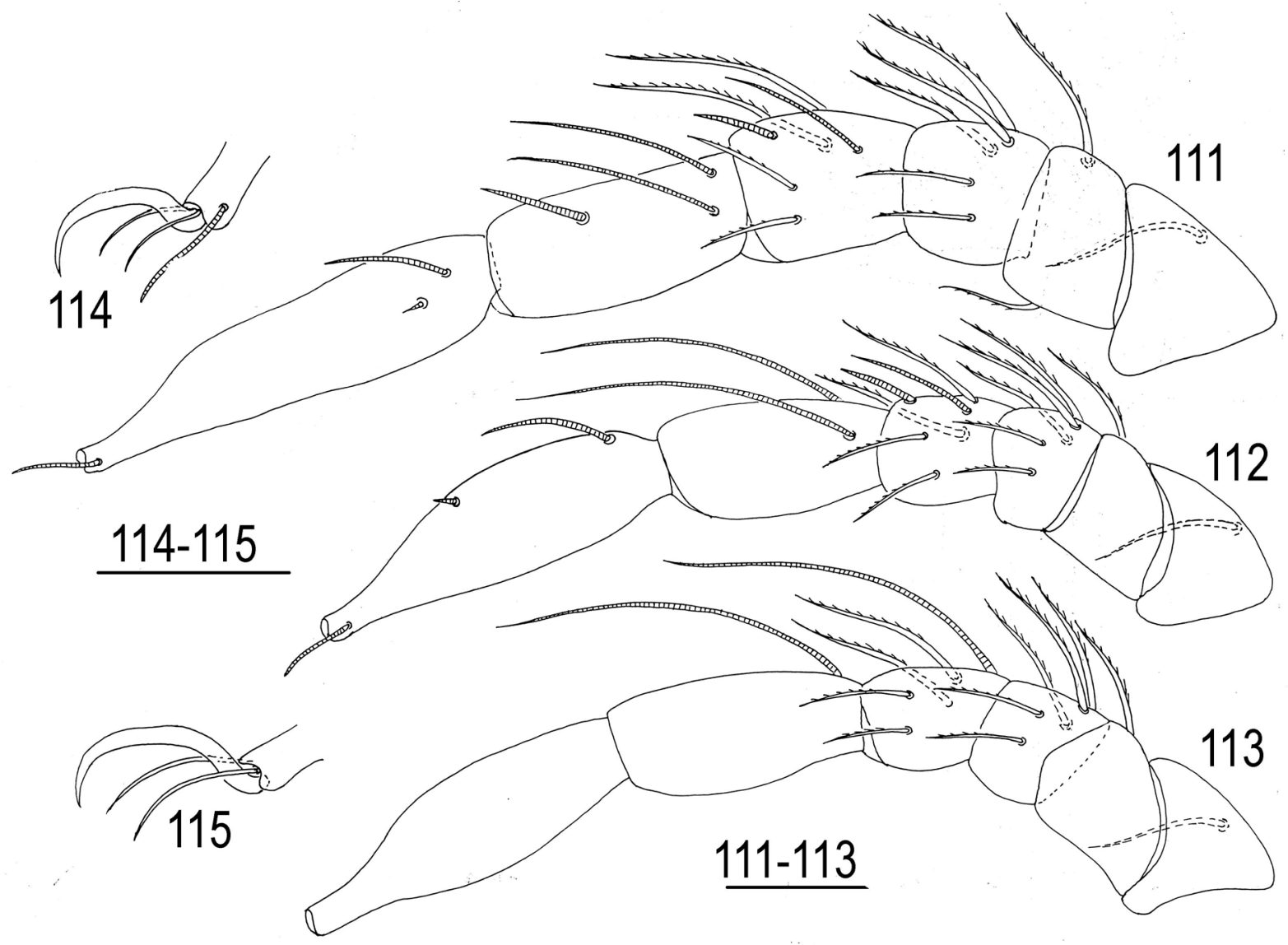

Figs. 111-115. Hydryphantes octoporus Koenike, 1896, larva: 111-I-Leg-1-6; 112 -II-Leg-1-6; 113-III-Leg-1-6; 114 - claws of leg I; 115 — claws of leg III. Simple setae on I-III-Leg-4-6 are not shown. Scale bars: $20 \mu \mathrm{m}$.

Remarks. Adults mites of $H$. octoporus are similar to those of $H$. thoni. Some acarologists consider $H$. thoni as a synonym of $H$. octoporus (Lundblad 1962, K. O. Viets 1978, Gerecke 1996). Both species are very simlar and differ mainly in the number of genital acetabula: H. octoporus with 8 acetabula (Fig. 120), H. thoni with 10-12 acetabula. The number of acetabula varies in representatives of the subgenus Polyhydryphantes, especially in the posterior portion of the external genital organ (Figs. 121-122), anterior acetabulum is occasionally doubled (Fig. 121). Larvae have been reared from two females with 8 acetabula, from three females with 10 acetabula, from one female with 11 acetabula and one female with 12 acetabula (Tuzovskij 2007). The morphology of all larvae is identical, and thus it is necessary to consider $H$. thoni as a junior synonym of $H$. octoporus.

\section{Hydryphantes placationis Thon, 1899}

(Figs. 123-138)

Material examined. 13 larvae were reared from single female (Samara Province) and 29 lar- vae from three females (Yaroslavl Province). The duration of the embryonic period was 10-14 days.

Diagnosis. Larva. Unpaired dorsal plate subquadrate, distance between bases of trichobothria $O i$ larger than their length, median eye situated between setae $V i$, trichobothria $F p$ very long, setae $F c h$ shorter than $V i$, all dorsal hysterosomal setae subequal, but setae Le shorter than others setae; bases of setae $A i$ and excretory pore situated distally; basal segment of chelicera with numerous thin strips, P-4 dorsodistal claw with two distinctly unequal clawlets; P-5 solenidion longer of segment; I/II-Leg-4 solenidion and eupathidium subequal in length; I/II-Leg-5 with subequal solenidia; I-Leg-6 de $\leq d s$.

Larva. Anterior pair of platelets more or less triangular, posterior plate suquadrate; median eye situated between setae $V i$ (Fig. 123). Both pairs of trichobothria thin, $F p$ very long and well extending to posterior margin of dorsal plate. Distance between bases of trichobothria $\mathrm{Oi}$ larger than their length. Setae $F c h$ shorter than $V i$. Dorsal setae (Oe, $\mathrm{Hi}, \mathrm{He}, \mathrm{Sci}$, Sce, and $\mathrm{Li}$ ) thick and approximately equal in length, and Le shorter than these setae. 

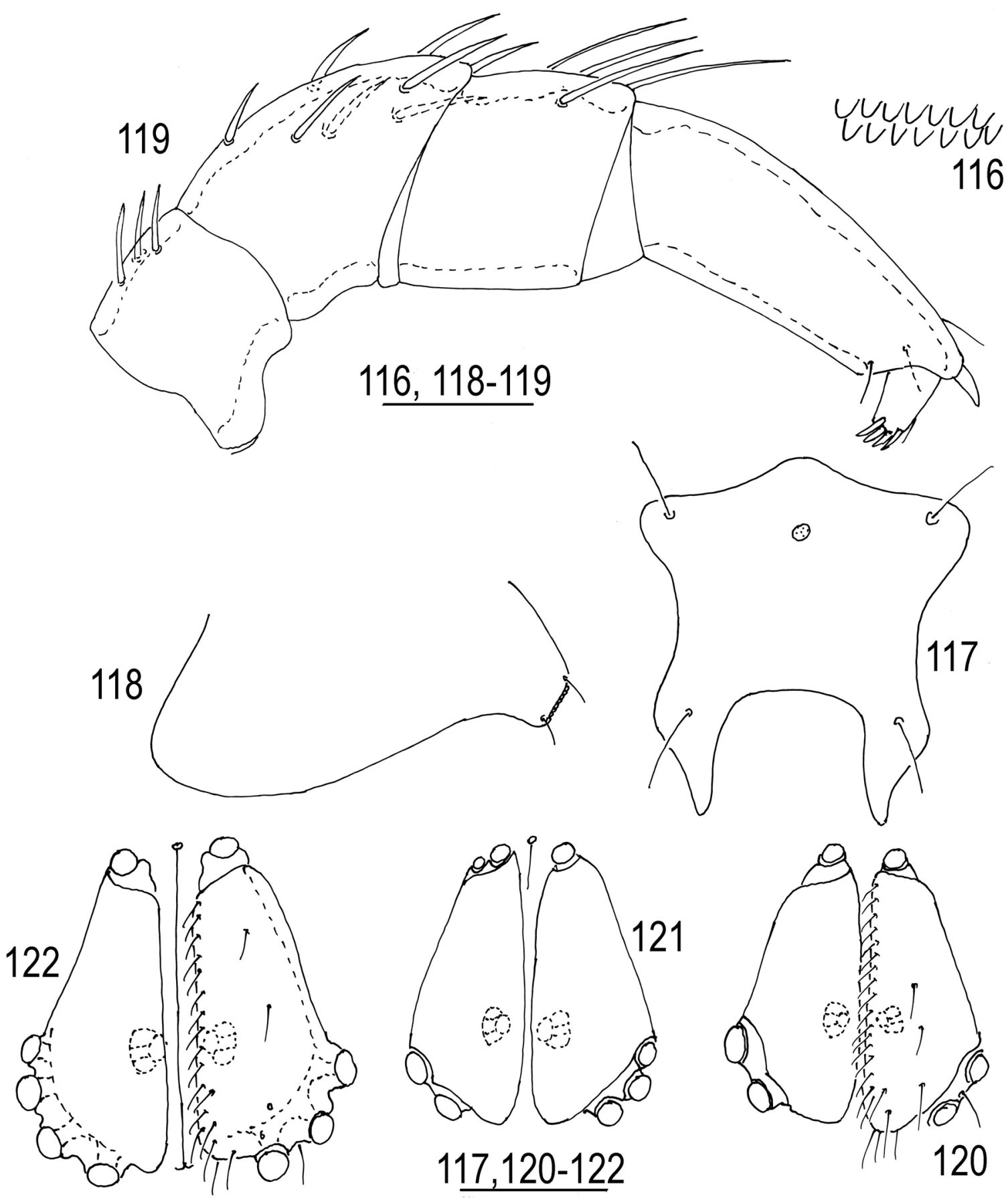

Figs. 116-122. Hydryphantes octoporus Koenike, 1896, female: 116-fragment of integument; 117-frontal plate; 118 - capitulum, lateral view; 119-pedipalp; 120-122—genital field. Scale bars: $116,118-119=50 \mu \mathrm{m} ; 117,120$ $122=100 \mu \mathrm{m}$.

Anterior and posterior lateral eyes subequal and circular.

Coxal plates II triangular, with straight or slightly convex posterior margin; coxal plates I and III more or less trapezoidal and rounded medially (Fig. 124). All coxal setae short and subequal. Urstigma moderately in size and situated in lateral part of coxal plate II. Setae Si longer than other ventral idiosomal setae. Setae $\mathrm{Se}, \mathrm{Ci}, \mathrm{Pi}$, and $\mathrm{Pe}$ subequal and slightly longer and thicker than both pairs of anal setae. Excretory pore plate (Figs. 125-126) small as long as wide or slightly wider than long (L/W ratio 1.0-1.1), bases of setae $A i$ and excretory pore situated distally.

Basal segment of chelicera with rather numerous thin strips (Fig. 127). 

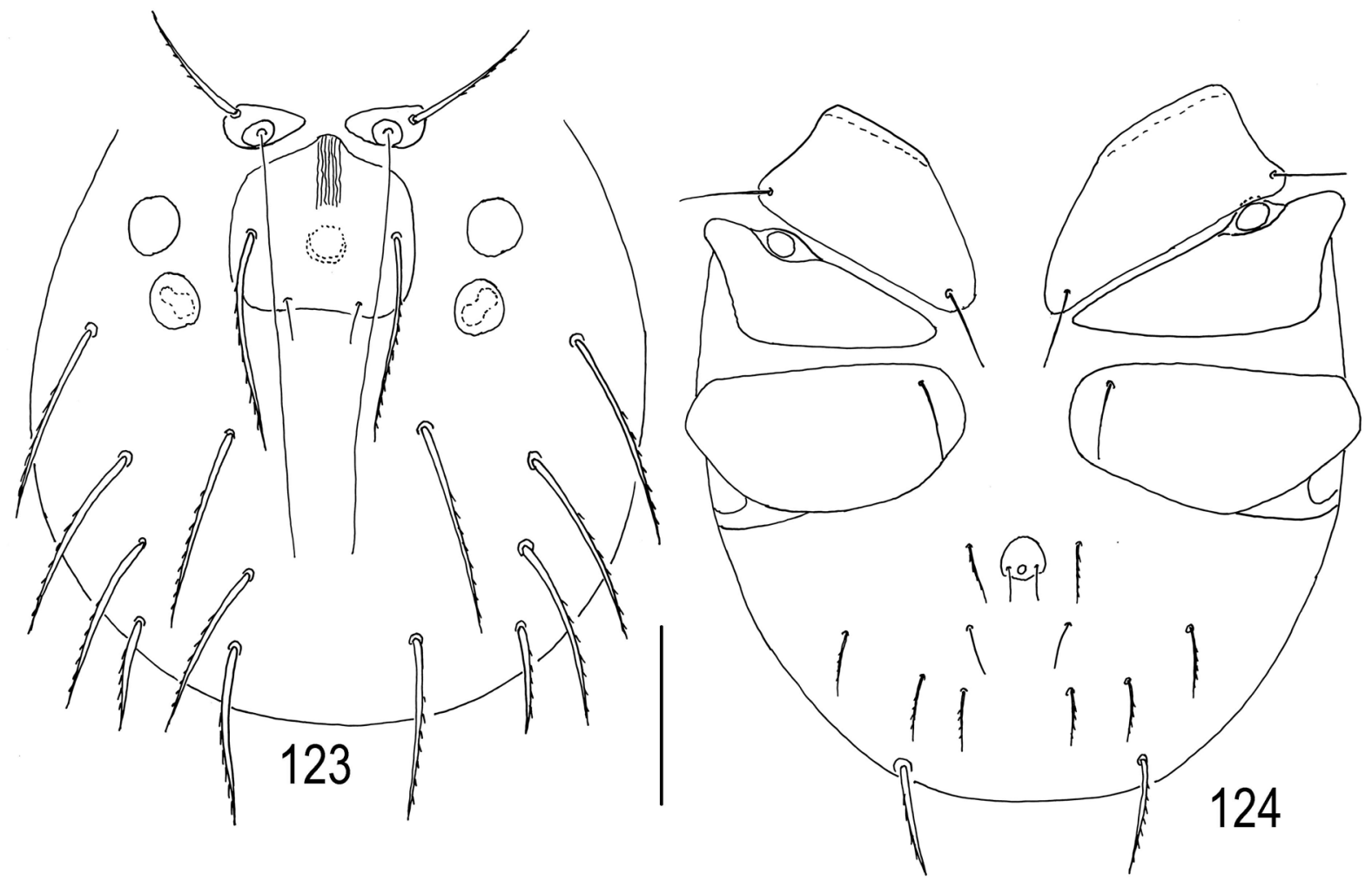

Figs. 123-124. Hydryphantes placationis Thon, 1899, larva: 103—dorsal view; 104 —entral view. Scale bar: $50 \mu \mathrm{m}$.

Pedipalps stout (Fig. 128): P-2 large with convex dorsal margin and single dorsal seta near middle of segment; P-3 with two unequal setae (long, thick proximal and short, thin distal); P-4 with three thin unequal setae and large claw with two unequal clawlets; P-5 small conical, with a long solenidion and seven setae, five long, thick and two short, thin.

Shape and arrangement of specialized setae on terminal legs segments as shown in Figs. 129-131. I/II-Leg-4 solenidion and eupathidium subequal in length, I/II-Leg-5 with two subequal proximal solenidia; I-Leg-6 de equal or shorter than I-Leg-6 $d s$. Claws of leg III (Fig. 133) slightly larger than claws of legs I and II (Fig. 132).

Measurements, $\mathrm{n}=10$. Dorsal plate L 35-42, W 40-44; setae Fch L 28-35, setae Fp L 80-88, setae $V i$ L 43-48, setae Oi L 7-10, setae Oe, Hi, He, Sci, $S c e$, and $L i$ L 32-36, setae $L e$ and $S i$ L 22-26; setae $\mathrm{Se}, \mathrm{Ci}, \mathrm{Pi}$, and $P e \mathrm{~L}$ 13-16; setae $A i$ and $A e \mathrm{~L} 10-12$; distance between setae $V i-V i$ 27-32, distance between setae $O i-O i$ 15-19; excretory pore plate L 10-12, W 10-14; basal segments of chelicera L 72-82, chela L 17-19; pedipalpal segments (P-1-5) L: 5-6, 30-38, 18-25, 15-18, 9-11; legs segments L: I-Leg-1-6: 20-24, 21-25, 18-23, 27-30, 35-42, 52-62; II-Leg-1-6: 22-25, 17-20, 12-15, 16-19,
27-30, 46-48; III-Leg-1-6: 22-27, 17-23, 12-15, 18-22, 28-32, 41-44.

Female. Integument soft, with rounded papillae (Fig. 134). Frontal plate (Fig. 135) with short bluntly pointed medioanterior protrusion and long posterior projections, median eye small and situated slightly posterior to anterior pair of setae.

Capitulum with short rostrum (Fig. 136). Pedipalp (Fig. 137) robust: P-1 with one to four dorsodistal setae; P-2 with 9-13 setae; P-3 shorter than high, with two to three (occasionally four) setae; P-4 tapering distally, with three thin distal unequal setae and a short, thick dorsodistal spine.

Genital field (Fig. 138) with three acetabula (posterior acetabula very large) and 25-40 thin setae on each side.

Measurements, female $(\mathrm{n}=5)$. Idiosoma $\mathrm{L}$ 1500-2500; dorsal plate L 375-440, W 410-440; genital flap L 285-325, W 110-140; genital acetabula (ac.1-ac.3) D 40-50, 35-50, 85-90; capitulum L 310-325, rostrum L 25-50, chelicera L 310-325, chela L 110-125; pedipalpal segments (P-1-5) L: 75-90, 125-140, 85-100, 160-175, 24-26; legs segments L: I-Leg-1-6: 85-100, 110-140, 150-175, 200-240, 235-250, 225-250; II-Leg-1-6: 90-100, 135-150, 185-215, 300-315, 335-350, 310-325; III-Leg-1-6: 100-115, 135- 

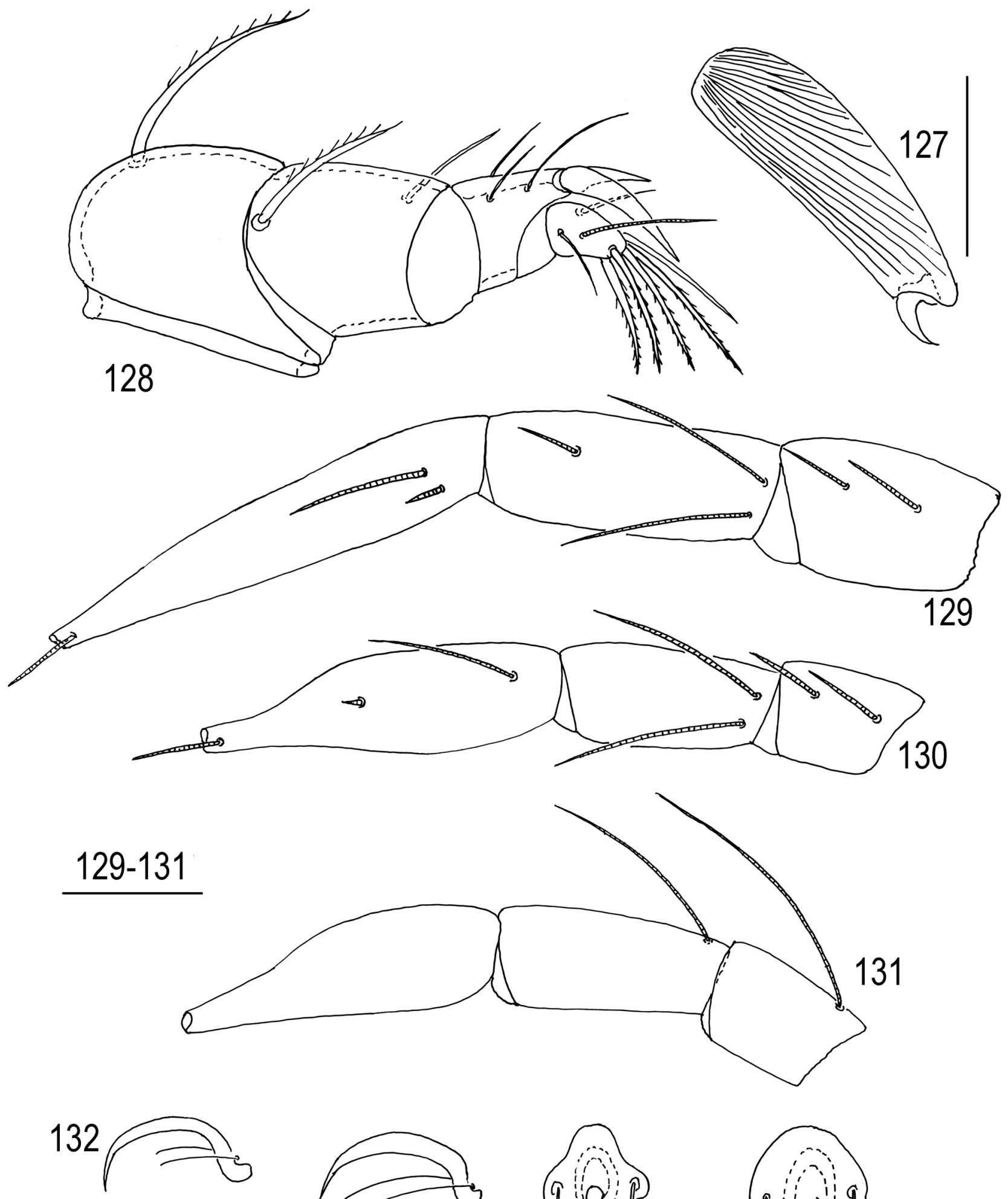

$125-126,128,132-133$
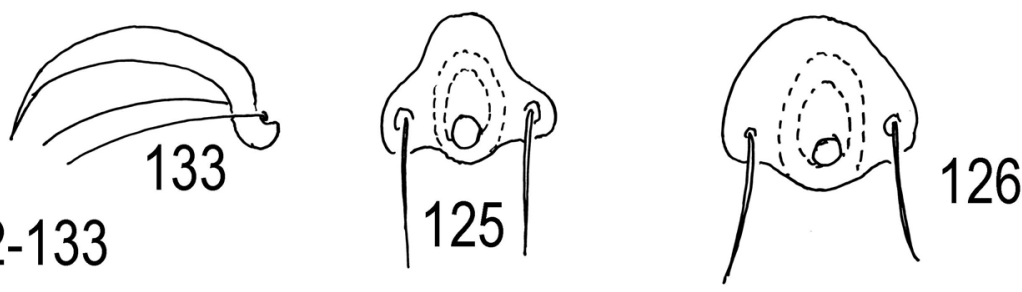

Figs. 125-133. Hydryphantes placationis Thon, 1899, larva: 125-126-excretory pore plate; 127-basal segment of chelicera, dorsal view; 128 - pedipalp, lateral view; 129-I-Leg-4-6; 130-II-Leg-4-6; 131-III-Leg-4-6; 132 — claws of leg I; 133-claws of leg III. Simple setae on I-III-Leg-4-6 are not shown. Scale bars: 125-126, 128, 129-131, $132-133=20 \mu \mathrm{m} ; 127=50 \mu \mathrm{m}$. 


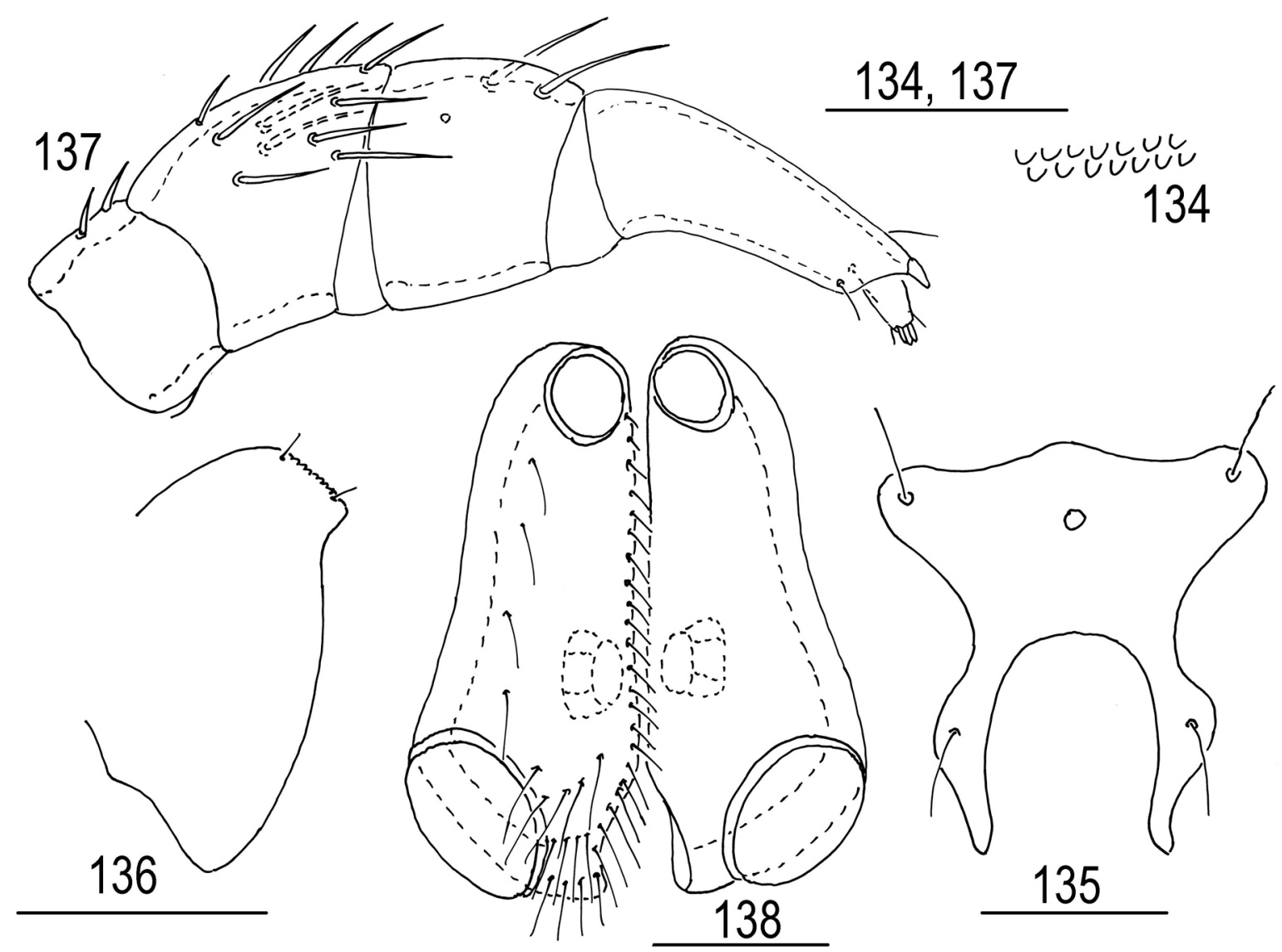

Figs. 134-138. Hydryphantes placationis Thon, 1899, female: 134 - fragment of integument; 135-frontal plate; 136capitulum, lateral view; 137 -pedipalp; 138 —genital field. Scale bars: 134, 137, 138=100 $\mu \mathrm{m} ; 135,136=100 \mu \mathrm{m}$.

$165,200-225,310-325,350-365,310-325$; IVLeg-1-6: 200-225, 185-215, 285-325, 410-450, 400-440, 335-350.

\section{Hydryphantes planus Thon, 1899}

(Figs. 139-151)

Material examined. Larvae $(n=8)$ were reared from a single female collected in a sedge bog near village Postyltsevo, Nekouz District, Yaroslavl Province 19 June 1974, leg P.V. Tuzovskij. The duration of the embryonic period was 14 days.

Diagnosis. Larva. Distance between bases of trichobothria $O i$ larger than their length; setae $F c h$ shorter than $V i$, all dorsal hysterosomal setae subequal; median eye situated between setae $V i$; excretory pore plate usually as long as wide or slightly longer than wide; posterior margin of coxal plate II straight; P-5 with short solenidion; I-Leg-4 solenidion shorter than eupathidium, II-Leg-4 solenidion longer than eupathidium; I/II-Leg-5 with subequal solenidia; I-Leg- $6 d e=d s$.

Larva. Anterior pair of platelets triangular or oval, trichobothria $F p$ long and well extending to posterior margin of dorsal plate; seta $F c h$ thick and half the length of $F p$ (Fig. 139). Posterior plate anteriorly narrow posteriorly widening; median eye rather large and situated between setae $V i$; setae $V i$ thick, longer than $F c h$; Oi short, distance between $O i-O i$ larger than their length. Other dorsal setae (Oe, Hi, He, Sci, Sce, Li, Le, and $\mathrm{Si}$ ) thick and subequal.

Coxal plates II triangular with straight posterior margin, coxal plates I and III more or less trapezoidal and rounded medially (Fig. 140); all coxal setae relatively short and subequal. Urstigma oval, longer than wide. Setae $S i$ longer than other ventral idiosomal setae. Setae $\mathrm{Se}, \mathrm{Ci}, \mathrm{Pi}$, and $\mathrm{Pe}$ subequal and slightly longer and thicker than both pairs of anal setae.

Excretory pore plate small, usually longer than wide (Figs. 141-142), excretory pore located near posterior plate margin. Bases of setae $A i$ situated near middle of excretory pore plate.

Chelicera (Fig. 143) with large basal segment and small chela. Basal segment with rather wide strips.

Pedipalps stout (Fig. 144): P-2 large with convex dorsal margin and single dorsal setae 

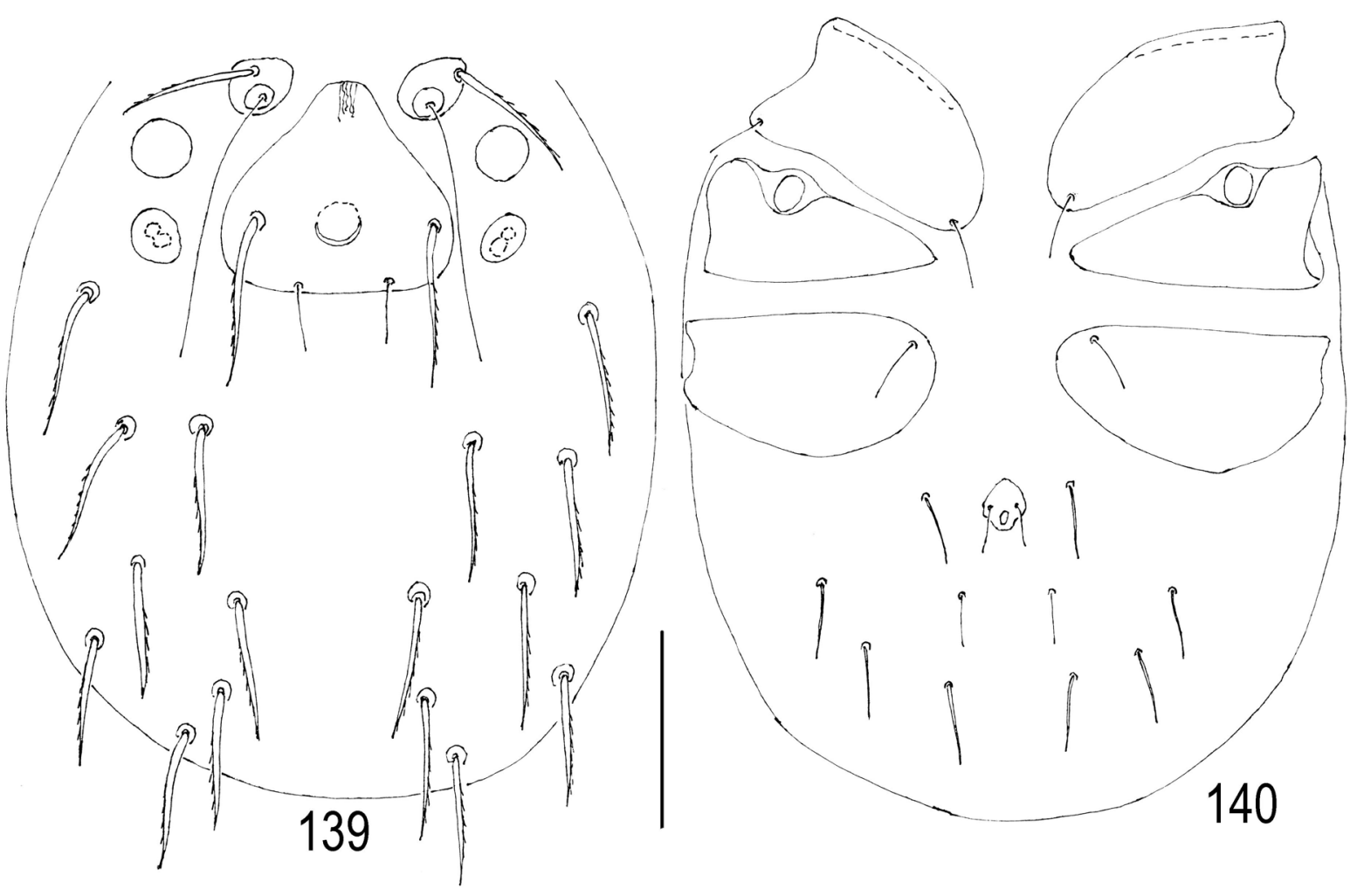

Figs. 139-140. Hydryphantes planus Thon, 1899, larva: 139—dorsal view; 104—ventral view. Scale bar: $50 \mu \mathrm{m}$.

proximally to middle of segment; P-3 with two subequal setae (proximal and distal); P-4 with three thin subequal setae, dorsodistal claw large with subequal clawlets; P-5 small, with a single, short solenidion and seven setae, five long and, thick, two short and thin.

Shape and arrangement of specialized setae on terminal segments as shown in Figs. 145-147. ILeg-4 solenidion slightly shorter and thinner than eupathidium, I/II-Leg-5 proximal solenidia subequal, I-Leg-6 eupathidium short and situated on equal level with the solenidion basis; II-Leg-4 solenidion 1.5-2.0 times longer than eupathidium; III-Leg-4 proximal solenidion slightly longer than III-Leg-5 solenidion. Empodium large and crescent-shaped on all tarsi, ambulacra short and thin (Fig. 148).

Measurements, $\mathrm{n}=8$. Dorsal plate L 45-48, $\mathrm{W}$ 48-51; setae Fch L 25-29, setae Fp L 55-65, setae $V i$ L 37-42, setae $\mathrm{Oi}$ L 9-13, setae $\mathrm{Oe}, \mathrm{Hi}, \mathrm{He}$, Sci, $\mathrm{Sce}, \mathrm{Li}, \mathrm{Le}$, and $\mathrm{Si} \mathrm{L}$ 28-35; setae $\mathrm{Ci}, \mathrm{Se}, \mathrm{Pi}, \mathrm{Pe}$ 15-19; setae $A i$ and $A e$ 8-10; distance between setae $\mathrm{Vi}-\mathrm{Vi}$ 35-38, distance between setae $\mathrm{Oi}-\mathrm{Oi}$ 19-20; excretory pore plate L $11-13$, W $10-12$; urstigma L 12-13, W 10-11; basal segments of chelicerae L 73-77, chela L 19-23; pedipalpal segments (P-1-5) L: 6-8, 27-29, 16-19, 19-20, 10-12; leg segments L: I-Leg-1-6: 21-23, 19-20, 16-19, 25-29, 34-38, 60-65; II-Leg-1-6: 19-23, 8-10, 12-16, 15-17, 31-33, 44-48; III-Leg-1-6: 22-24, 8-10, 15-17, 19-20, 31-33, 44-45.

Female. Integument soft, with rather short rounded papillae. Frontal plate (Fig. 149) compact, anterior margin obtuse-angled, lateral and posterior margins usually concave, anterior part wider than posterior one, posterior projections short. Median eye small and situated between or slightly posterior to anterior setae.

Capitulum (Fig. 150) with equally convex basal part and short rostrum (base of capitulum/ rostrum $\mathrm{L}$ ratio $7.0-8.0$ ).

Pedipalp moderately long (Fig. 151): P-1 with 3-5 dorsodistal setae; P-2 with 13-18 setae; P-3 with 4-7 setae; P-4 slender with three thin distal setae and short, thick dorsodistal spine.

Measurements, $\mathrm{n}=2$. Idiosoma L 1100-1500; dorsal plate L 425-440, W 385-400; genital flap L 235-250, W 110-125; genital acetabula (ac.1-ac.3) L 45-50, 30-37, 50-65; capitulum L 265-275, rostrum L 35-45, chelicera L 360-375, chela L 120-125; pedipalpal segments (P-1-5) L: 70-80, 115-125, 75-90, 180-200, 30-35; leg segments L: I-Leg-1-6: 80-85, 120-130, 145-155, 230-250, 250-270, 260-275; II-Leg-1-6: 100-105, 145-155, 


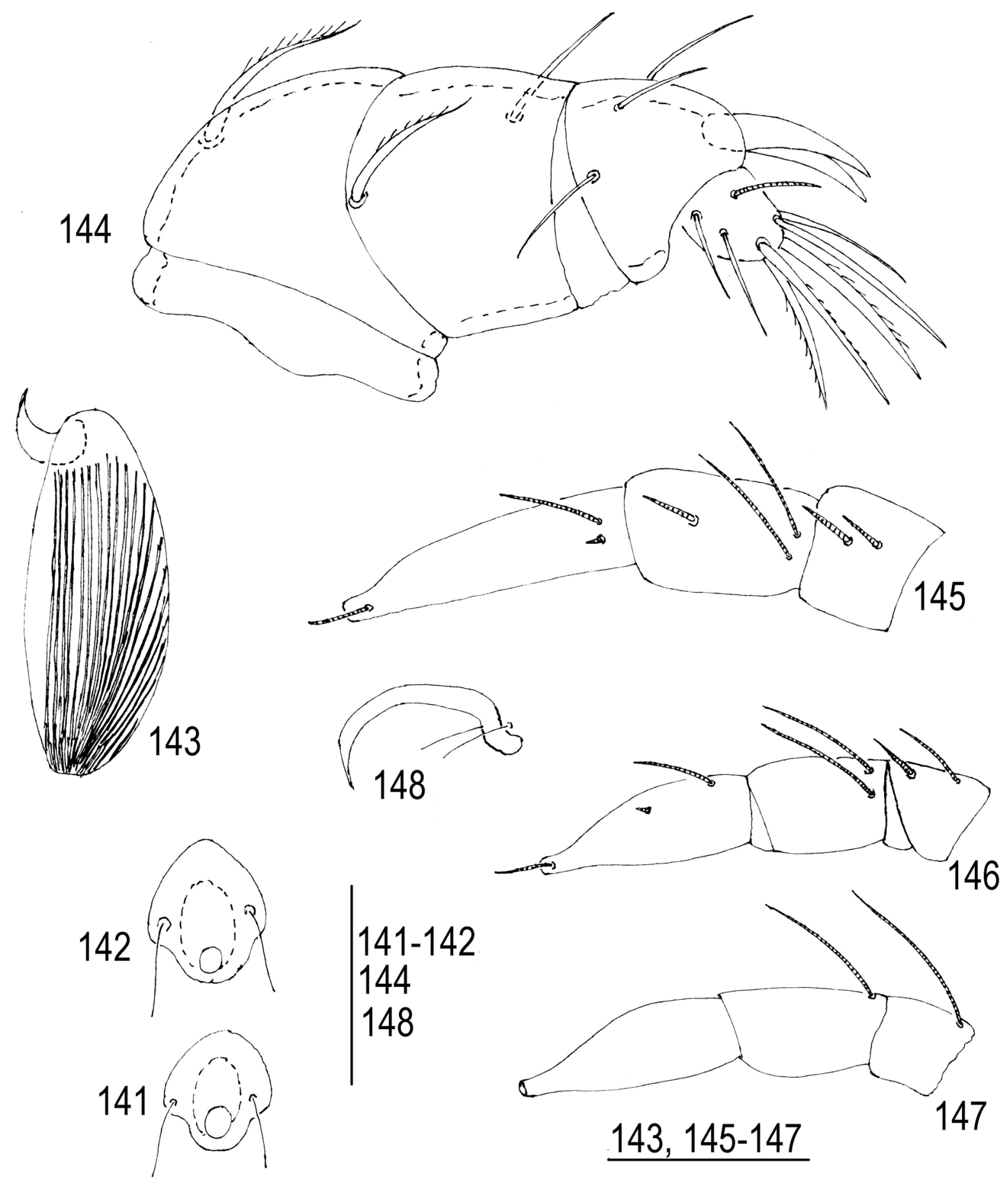

Figs. 141-148. Hydryphantes planus Thon, 1899, larva: 141-142-excretory pore plate; 143-basal segment of chelicera, dorsal view; 144—-pedipalp, lateral view; 145-I-Leg-4-6; 146-II-Leg-4-6; 147-III-Leg-4-6; 148claws of leg I; 133 - claws of leg III. Simple setae on I-III-Leg-4-6 are not shown. Scale bars: 141-142, 144, 148=20 $\mu \mathrm{m} ; 145-147=50 \mu \mathrm{m}$.

180-190, 300-315, 360-375, 345-355; IIILeg-1-6: 100-110, 130-140, 180-190, 330-345, 370-380, 345-355; IV-Leg-1-6: 205-215, 205220, 280-290, 430-440, 430-445, 345-355.

Remarks. Larvae attributed to $H$. planus by Wainstein (1980) and Biesiadka and Cichocka
(1990) differ distinctly from the description given here and represent obviously two different species. The larva described by Wainstein (1980) as $H$. planus is the larva of H. hellichi (Tuzovskij 2014c).

The H. planus larvae described here are morphologically similar to the larvae described under 


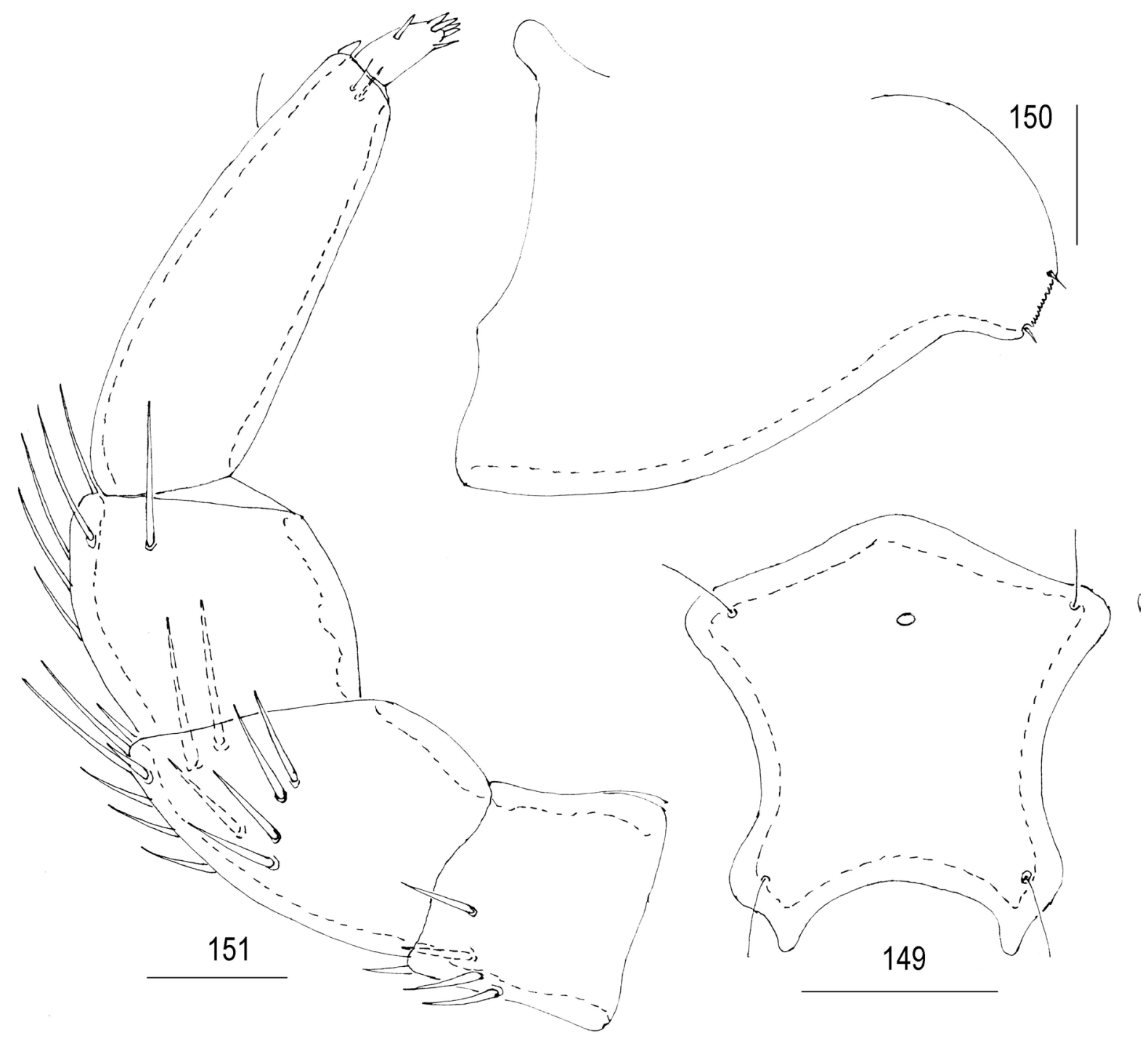

Figs. 149-151. Hydryphantes planus Thon, 1899, female: 149-frontal plate; 150 —capitulum, lateral view; 151pedipalp. Scale bars: $149=200 \mu \mathrm{m} ; 150=100 \mu \mathrm{m} ; 151=50 \mu \mathrm{m}$.

this name by Biesiadka and Cichocka (1990), but there are some distinctions. The median eye in the Polish larvae is situated posterior to, not between setae $V i$, and the $\mathrm{P}-3$ is shorter $(\mathrm{L}=17 \mu \mathrm{m})$ (Biesiadka and Cichocka 1990). These differences suggest that the larvae described from Poland belong to a species different from $H$. planus.

\section{Hydryphantes prolongatus Thon, 1899}

(Figs. 152-169)

Material examined. Larvae $(n=38)$ were reared from six females (Yaroslavl Province): two female 28 May 2000, one female 4 July 2001, two females 27 May 2002 and one female 17 June 2004. The duration of the embryonic period was $12-15$ days.
Diagnosis. Larva. Distance between bases of trichobothria $O i$ larger than their length; median eye situated between setae $V i$; all dorsal hysterosomal setae subequal; basal segment of chelicera with numerous thin strips; excretory pore plate wider than long; convex; P-5 with long solenidion; I/II-Leg-4 solenidion much longer than eupathidium, I-Leg-6 $d e<d s$.

Larva. Anterior pair of dorsal platelets triangular or oval (Fig. 152). Posterior plate slightly wider than long (L/W ratio 0.81-0.95), narrowed anteriorly and widened posteriorly; median eye slightly developed and situated between setae $V i$; $\mathrm{Fch}$ shorter $\mathrm{V} i \mathrm{O} i$ short, distance between $\mathrm{Oi}-\mathrm{Oi}$ larger than their length; trichobothria $F p$ very long and well extending to posterior tips of setae $V i$. Other dorsal setae $\mathrm{Oe}, \mathrm{Hi}, \mathrm{He}, \mathrm{Sci}$, Sce, $\mathrm{Li}$, Le, and 

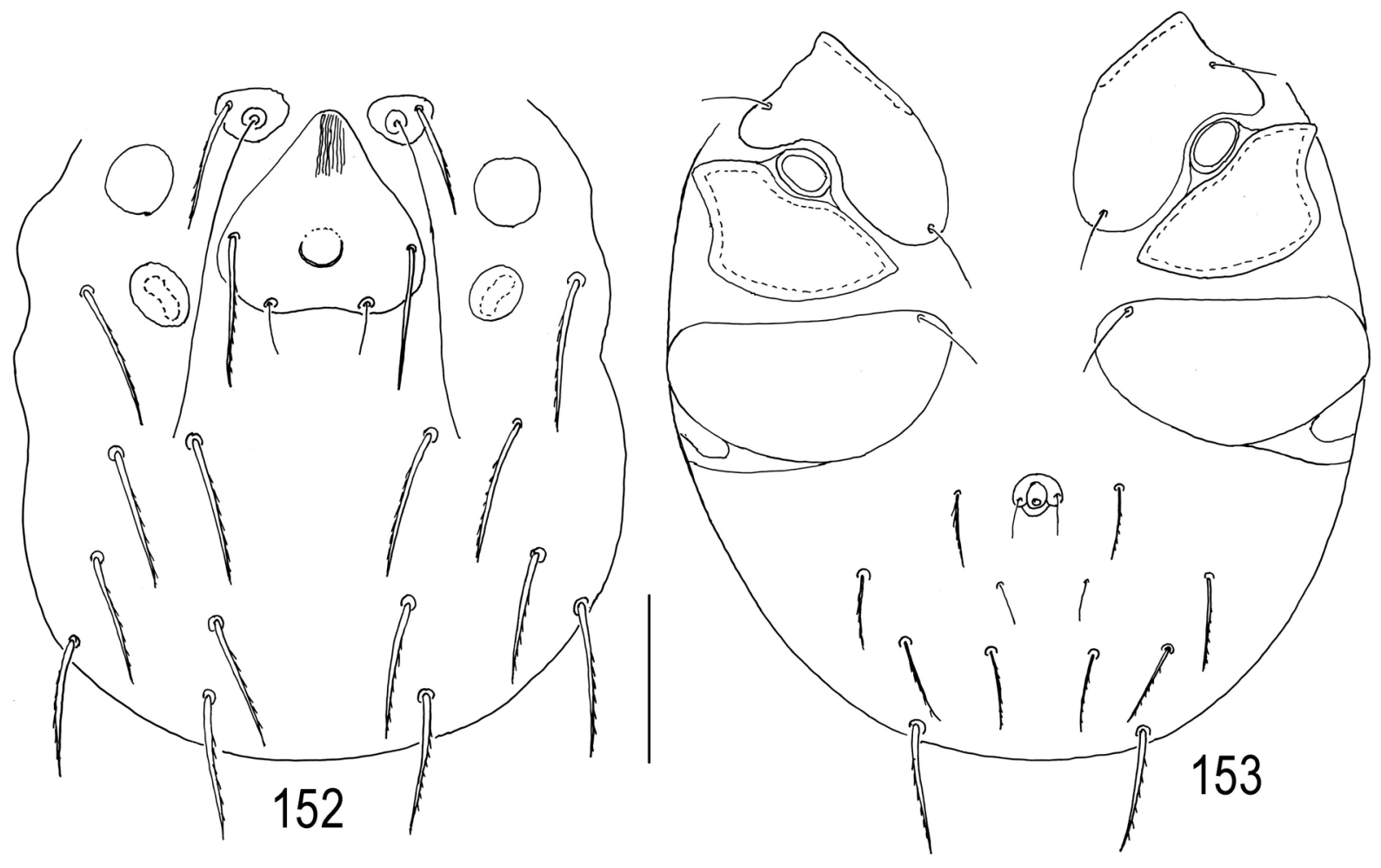

Figs. 152-153. Hydryphantes prolongatus Thon, 1899, larva: 152—dorsal view; 153—ventral view. Scale bar: $50 \mu \mathrm{m}$.

$S i$ subequal, their bases situated on very small sclerite.

Coxal plates II triangular with convex posterior margin, coxal plates I and III more or less trapezoidal and broadly rounded medially, all coxal setae short and subequal (Fig. 153). Urstigma comparatively large oval and wider than long. Setae $S i$ longer than other ventral idiosomal setae. Setae $S e, C i, P i$, and $P e$ subequal and slightly longer than both pairs of anal setae $(A i, A e)$.

Excretory pore plate small, wider than long (L/W ratio 0.81-0.91), its shape variable (Figs. 154-156).

Capitulum (Fig.157) with short, wide base. Posterior portion of basal part of capitulum with distinct reticulations. Basal segment of chelicera (Fig. 158) with numerous thin strips.

Pedipalps moderately long (Fig. 159): P-2 with convex dorsal margin and single dorsoproximal seta; P-3 with two unequal setae (thick proximal and relatively long, thin distal); P-4 with three unequal setae and large dorsodistal claw with subequal clawlets; P-5 solenidion longer of segment.

Shape and arrangement of specialized setae on terminal legs segments as shown in figures 160162. I/II-Leg-4 solenidion much longer than eupathidium, I-Leg-5 with two subequal long proximal solenidia and short distal eupathidium, I-Leg-6 de $<$ ds; II-Leg-5 with unequal proximal solenidion; III-Leg-4 proximal solenidion longer than III-Leg-5 solenidion. Empodium large and crescent on all tarsi, ambulacra I-II (Fig. 163) shorter than ambulacra III (Fig.164).

Measurements, $\mathrm{n}=10$. Dorsal plate L 43-48, W 50-54; setae Fch L 33-38, setae Fp L 80-88, setae $V i$ L 41-47, setae Oi L 10-15, setae $\mathrm{Oe}, \mathrm{Hi}, \mathrm{He}$, $\mathrm{Sci}$, Sce, $\mathrm{Li}$, Le, and $\mathrm{Si}$ L 35-42; setae $\mathrm{Ci}, \mathrm{Se}, \mathrm{Pi}$, $P e$ 19-22; setae $A i$ and $A e$ 13-15; distance between setae $\mathrm{Vi}-\mathrm{Vi} 42-48$, distance between setae $\mathrm{Oi}-\mathrm{Oi}$ 18-23; excretory pore plate L 11-13, W 13-14; urstigma L 10-11, W 12-15; basal segments of chelicerae L 80-85, cheliceral stylet L 22-25; strips on basal segment of chelicera W 0.6-1.0; pedipalpal segments (P-1-5) L: 6-7, 33-36, 27-30, 21-24, 11-14; legs segments L: I-Leg-1-6: 28-32, 25-28, 18-24, 31-38, 41-48, 80-90; II-Leg-1-6: 28-30, 21-24, 15-19, 21-24, 43-49, 68-72; III-Leg-1-6: 30-33, 18-24, 16-19, 25-28, 43-47, 61-68.

Female. Frontal shield subquadrate (L/W ratio 0.88-1.05), anterolateral extensions much wider than posterolateral extensions, anterior margin obtuse-angled (Fig. 165) or slightly convex, posterior margin straight, posterior projections short, their length equal to $1 / 4-1 / 6$ length of basal portion of plate. Median eye small and situated almost at level anterior setae. 


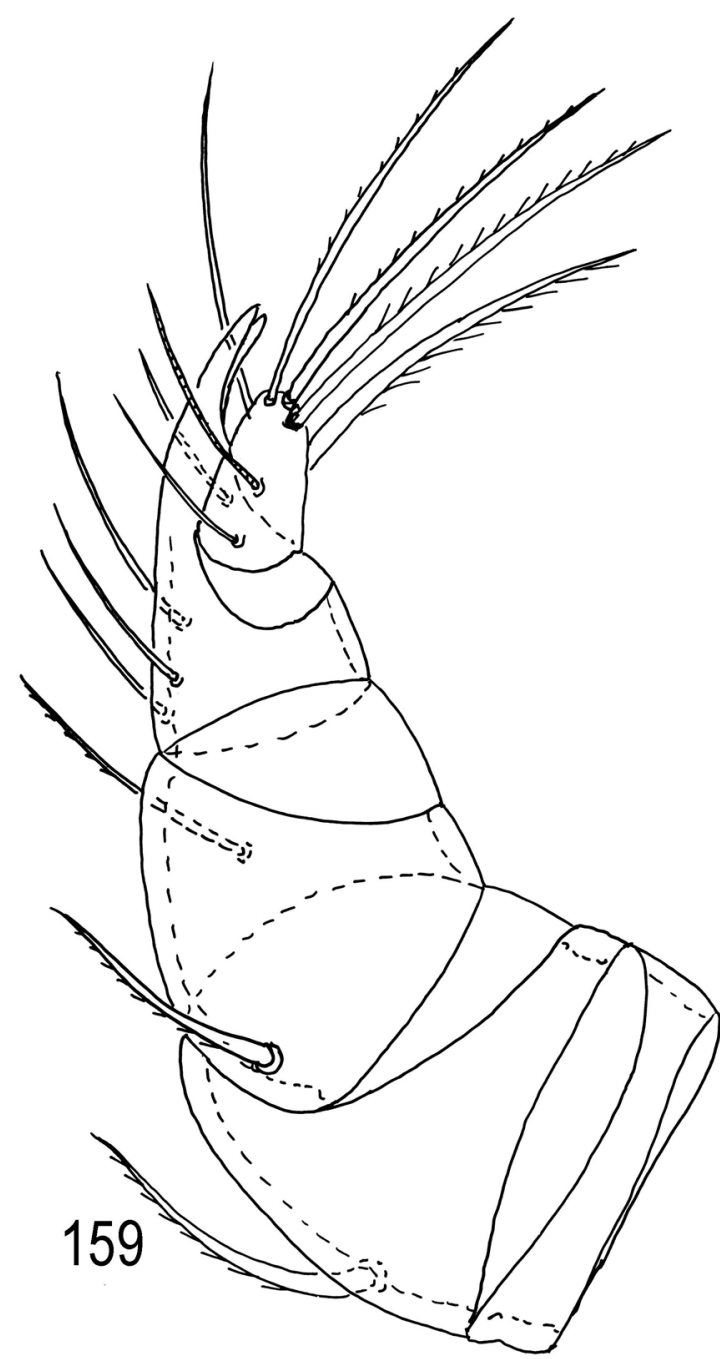

$154-156,159$
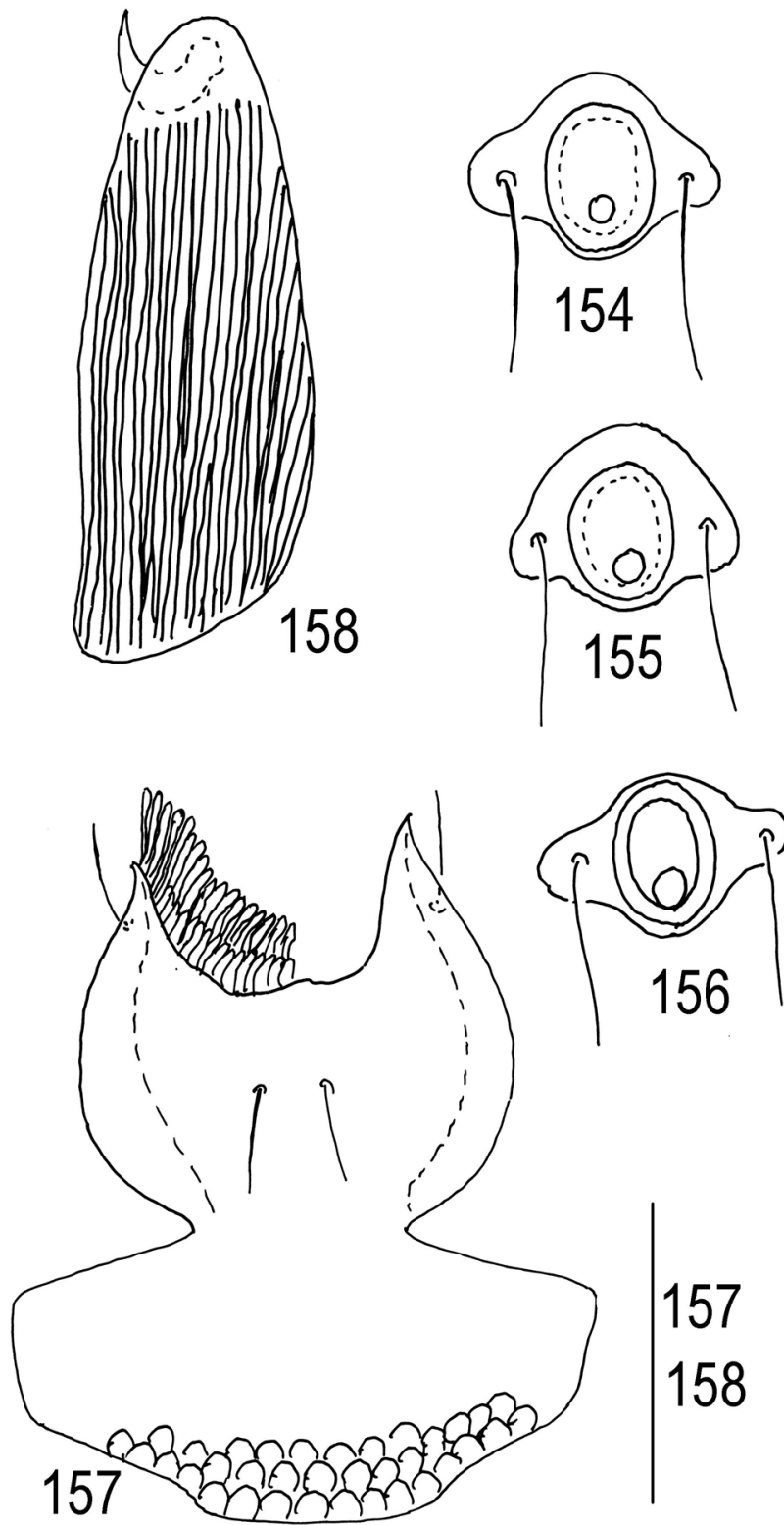

Figs. 154-159. Hydryphantes prolongatus Thon, 1899, larva: 154-156 — excretory pore plate; 157 capitulum, ventral view; 158 — basal segment of chelicera, dorsal view; 159_pedipalp, lateral view. Scale bars: 154-156, 159=20 $\mu \mathrm{m}$; $157-158=50 \mu \mathrm{m}$.

All coxal plates with numerous setae (Fig. 166). Genital field (Fig. 167) with three pairs of acetabula; anterior pair of acetabula large than second pair but slightly smaller than posterior pairs of acetabula. Acetabular plate elongate (L/W ratio 2.18-2.42), with $15-20$ pairs setae; posterior margin of plate oblique in antero-laterally direction.

Capitulum (Fig. 168) with long rostrum (base of capitulum/rostrum L ratio 2.4-3.0) and convex basal part.

Pedipalp compact (Fig. 169): P-1 with 3-5 dorsodistal setae; P-2 with 11-20 setae; P-3 with
6-10 setae; P-4 slender with four thin setae and short, thick dorsodistal spine.

Measurements, $(\mathrm{n}=10)$. Idiosoma L 1620-2200; dorsal plate L 560-600, W 500-590; genital flaps L 310-350, W 135-165; genital acetabula (ac.1-ac. 3) D 50-62, 37-45, 65-80; capitulum L 400-500, rostrum L 100-125, basal segment of chelicera L 435-525, cheliceral stylet L 210-240; pedipalpal segments (P-1-5) L: 100-115, 150-175, 110-150, 250-290, 25-35; legs segments L: I-Leg-1-6: 125-140, 135-165, 185-200, 275-300, 300-340, 310-350; II-Leg-1-6: 125-150, 175-200, 210-240, 375-415, 450-475, 435-490; III-Leg-1-6: 130 


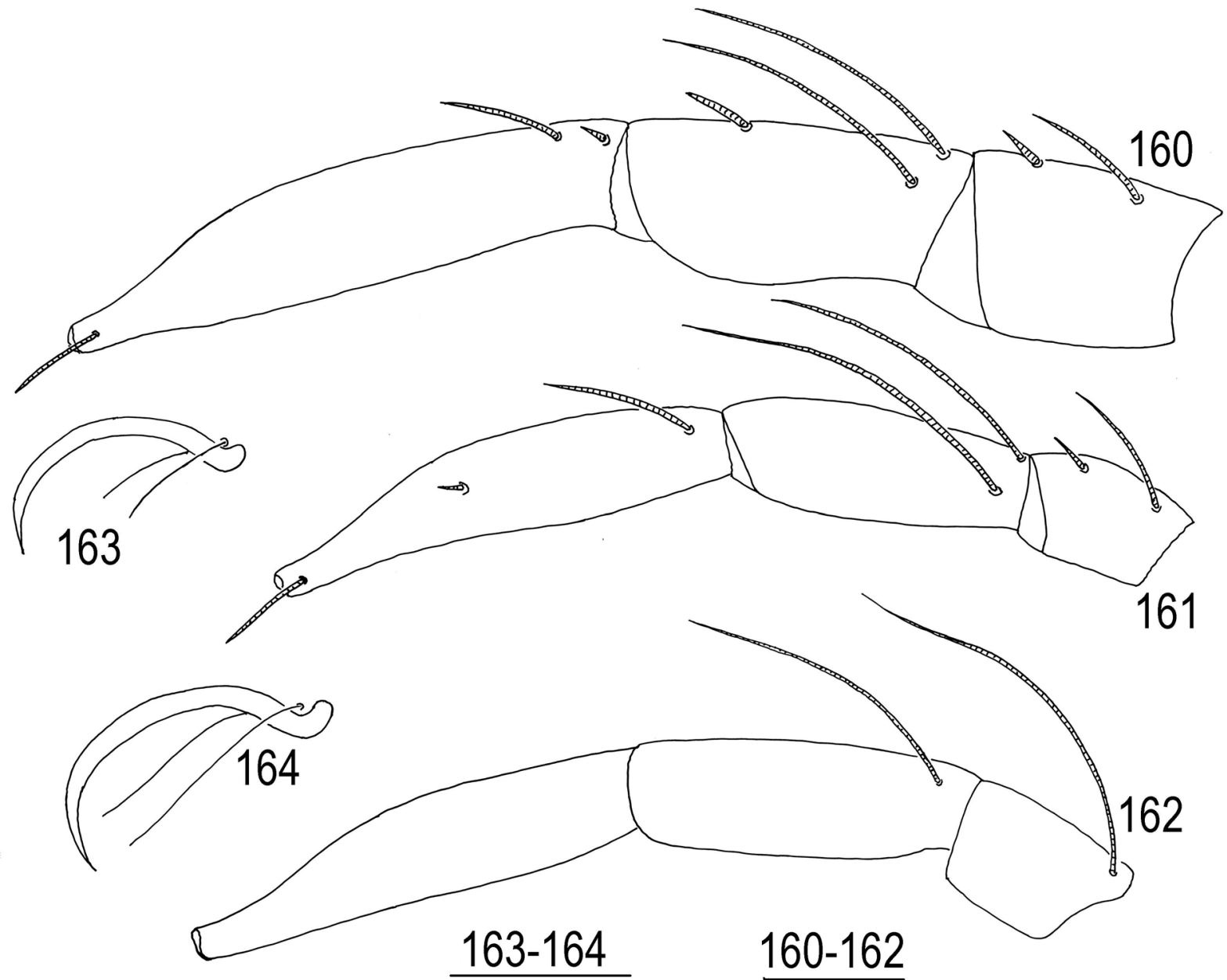

Figs. 160-164. Hydryphantes prolongatus Thon, 1899, larva: 160-I-Leg-4-6; 161-II-Leg-4-6; 162-III-Leg-4-6; 163 - claws of leg I; 164 - claws of leg III. Simple setae on I-III-Leg-4-6 are not shown. Scale bars: $20 \mu \mathrm{m}$.

$150,160-200,235-265,425-465,485-515$, 460-500; IV-Leg-1-6: 235-275, 235-275, 350390, 535-615, 535-600, 460-515.

Remarks. Originally $H$. prolongatus was described as a form of $H$. ruber and for a long time treated as a form or subspecies of this species (Thon 1899, Piersig 1897-1900; Soar and Williamson 1925; K. Viets 1936, 1956; Sokolow 1940; Szalay 1964, etc). Lundblad (1962) proposed synonymization with $H$. ruber, followed by Di Sabatino et al. (2010). The water mite Hydryphantes prolongatus is similar to H. ruber. However, clear differences have been found in the morphology of the larva, deutonymph and adults of $H$. prolongatus compared with the latter species (Tuzovskij 2015b), and $H$. prolongatus should be treated as a separate species.

\section{Hydryphantes ruber (Geer, 1778)}

(Figs. 170-183)

Material examined. Larvae $(n=23)$ were reared from two females (Yaroslavl Province), May
1975. The duration of the embryonic period was 11-14 days.

Diagnosis. Larva. Trichobothria $\mathrm{O} i$ long, distance between $\mathrm{Oi}-\mathrm{Oi}$ shorter than their length; median eye situated between setae $V i F c h$ shorter than $V i$, all dorsal hysterosomal setae subequal; basal segment of chelicera with thin strips; excretory pore plate as long as wide; P-4 dorsodistal claw with two subequal clawlets; P-5 solenidion longer of segment; I-Leg-4 solenidion 1.5-2.0 times longer than eupathidium; II-Leg-4 solenidion 2.0-3.0 times longer than eupathidium; I/IILeg-5 with unequal solenidia; I-Leg-6 $d e<d s$.

Larva. Anterior pair of dorsal platelets triangular or oval (Fig. 170). Posterior plate nearly as long as or slightly wider than long (L/W ratio $0.85-1.1)$, median eye slightly developed and situated between setae $\mathrm{Vi}$; Fch shorter $\mathrm{Vi}$; Oi long, distance between $\mathrm{Oi}-\mathrm{Oi}$ shorter than their length. Other dorsal setae (Oe, Hi, He, Sci, Sce, $\mathrm{Li}$, and $\mathrm{Le}$ ) thick and subequal. Anterior lateral eyes circular, posterior eyes elongate. 


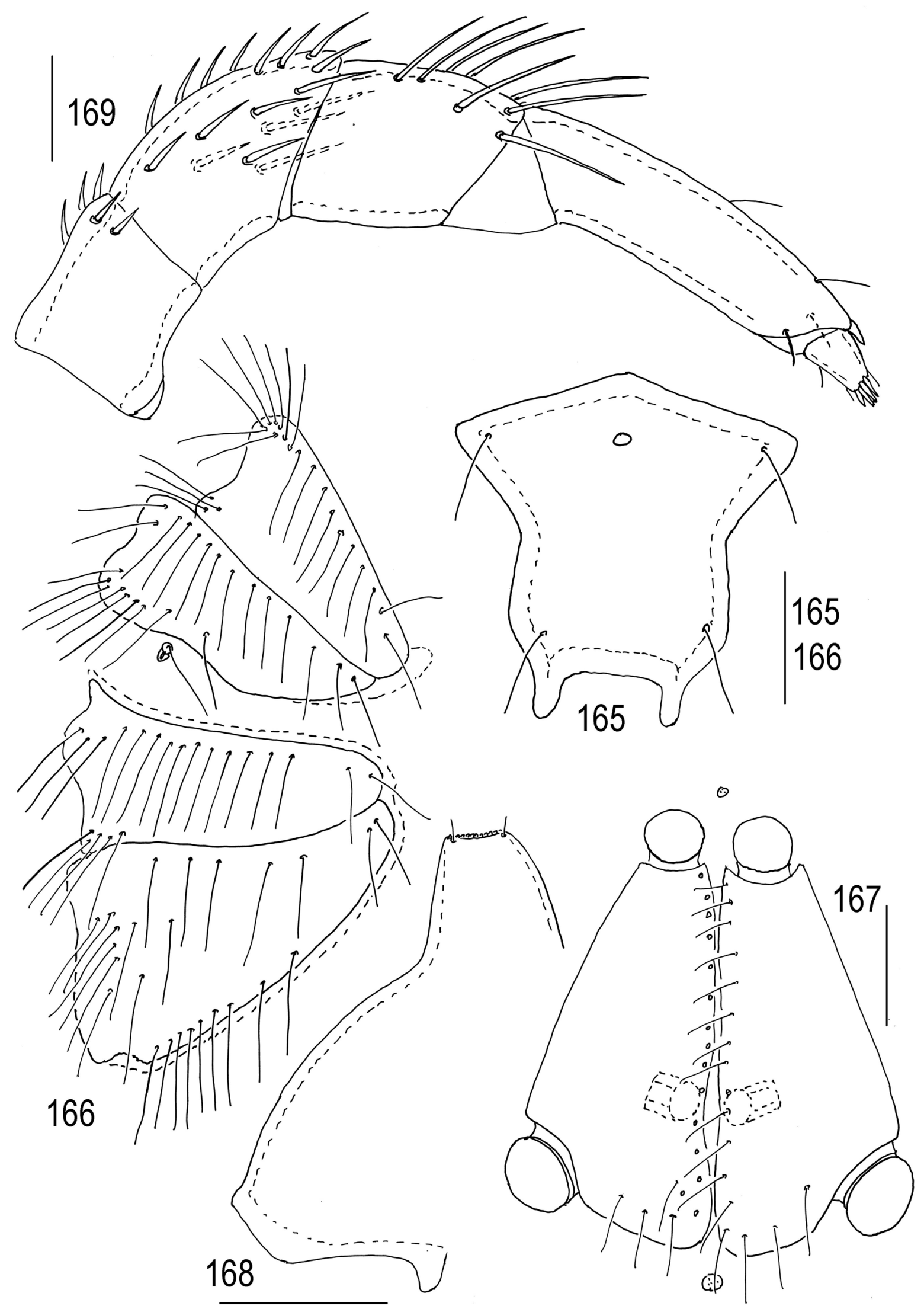

Figs. 165-169. Hydryphantes prolongatus Thon, 1899, female: 165-frontal plate; 166-coxal plates; 167-genital field; 168 — capitulum, lateral view; 169 —pedipalp. Scale bars: 165-166, 168=200 $\mu \mathrm{m} ; 167,169=100 \mu \mathrm{m}$. 

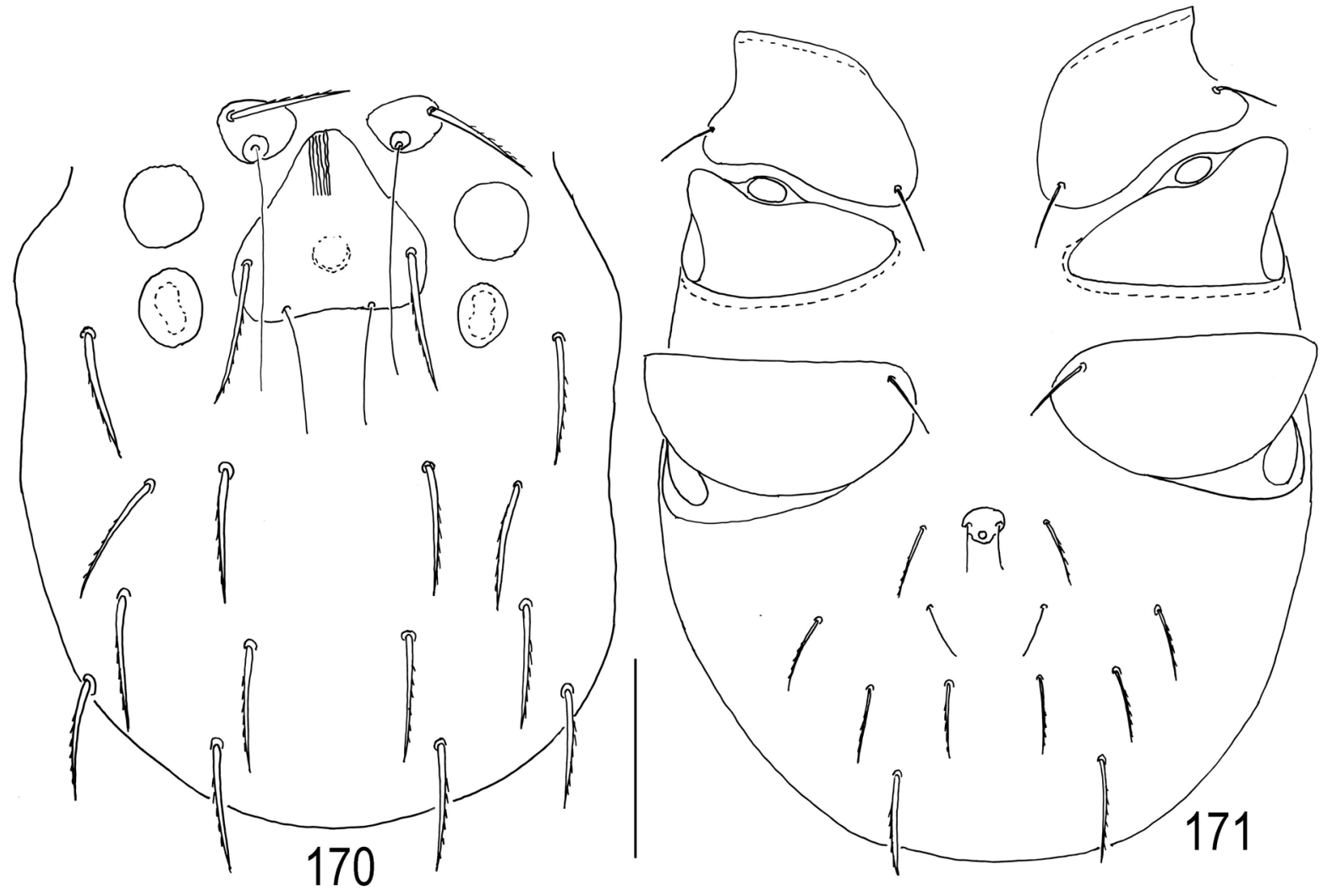

Figs. 170-171. Hydryphantes ruber (Geer, 1778), larva: 170_dorsal view; 153-ventral view. Scale bar: $50 \mu \mathrm{m}$.

Coxal plates II triangular with straight or slightly convex posterior margin, coxal plates I and III more or less trapezoidal and broadly rounded medially, all coxal setae short and subequal (Fig. 171). Urstigma oval, wider than long, moderately in size. Setae $S i$ longer and thicker than other ventral idiosomal setae. Setae $\mathrm{Se}, \mathrm{C} i, \mathrm{Pi}$ and $\mathrm{Pe}$ subequal and slightly longer than both pairs of anal setae ( $A i, A e)$. Excretory pore plate (Figs. 172-173) usually as long as wide or slightly wider than long (L/W ratio $0.80-1.10)$, excretory pore small and situated near posterior margin of plate.

Basal segment of chelicera (Fig. 174) with rather numerous thin strips, chela small and massive.

Pedipalps stout (Fig. 175): P-2 large with convex dorsal margin and a single dorsal seta proximally to middle of segment; P-3 with two unequal setae (long proximal and comparatively short distal); P-4 with three subequal thin setae and large dorsodistal claw with two subequal clawlets; P-5 solenidion longer of segment.

Shape and arrangement of specialized setae on terminal legs segments as shown in Figs. 176-178. I-Leg-4 solenidion 1.5-2.0 times longer than eupathidium; II-Leg-4 solenidion 2.0-3.0 times longer than eupathidium, I/II-Leg-5 with two unequal proximal solenidia; I-Leg- $6 \mathrm{de}<\mathrm{ds}$; III-
Leg-4-5 proximal solenidion subequal in length. I/II-Leg-6 with relatively long distal acanthoid setae. Empodium large and crescent on all tarsi, ambulacra short and thin (Fig. 179).

Measurements, $\mathrm{n}=10$. Dorsal plate L 41-48, W 45-49; setae Fch L 28-32, setae Fp L 60-63, setae $V i$ L 37-40, setae $O i$ L 25-35, setae $O e, H i$, $\mathrm{He}$, Sci, Sce, Li, Le and Si L 36-42; setae Ci, Se, $P i, P e$ 22-26; setae $A i$ and $A e$ 13-15; distance between setae $V i-V i$ 38-42, distance between setae $\mathrm{O} i-\mathrm{O} i \mathrm{18}-25$; excretory pore plate L 10-13, W 11-13; urstigma L 6-9, W 10-12; basal segments of chelicerae L 85-88, chela L 27-29; pedipalpal segments (P-1-5) L: 6-7, 28-34, 2124, 18-23, 11-13; legs segments L: I-Leg-1-6: $22-25,22-25,20-25,30-33,37-43,72-75$; IILeg-1-6: 22-29, 21-25, 13-15, 20-23, 36-38, 63-65; III-Leg-1-6: 25-30, 17-20, 15-17, 23-25, $41-44,60-63$.

Female. Integument soft, with rather short rounded papillae. Frontal plate (Fig. 180) subquadrate, anterior margin obtuse-angled, lateral margins concave, posterior margin straight, anterior part wider than posterior one, posterior projections short. Median eye small and situated between or slightly posterior to anterior setae. 

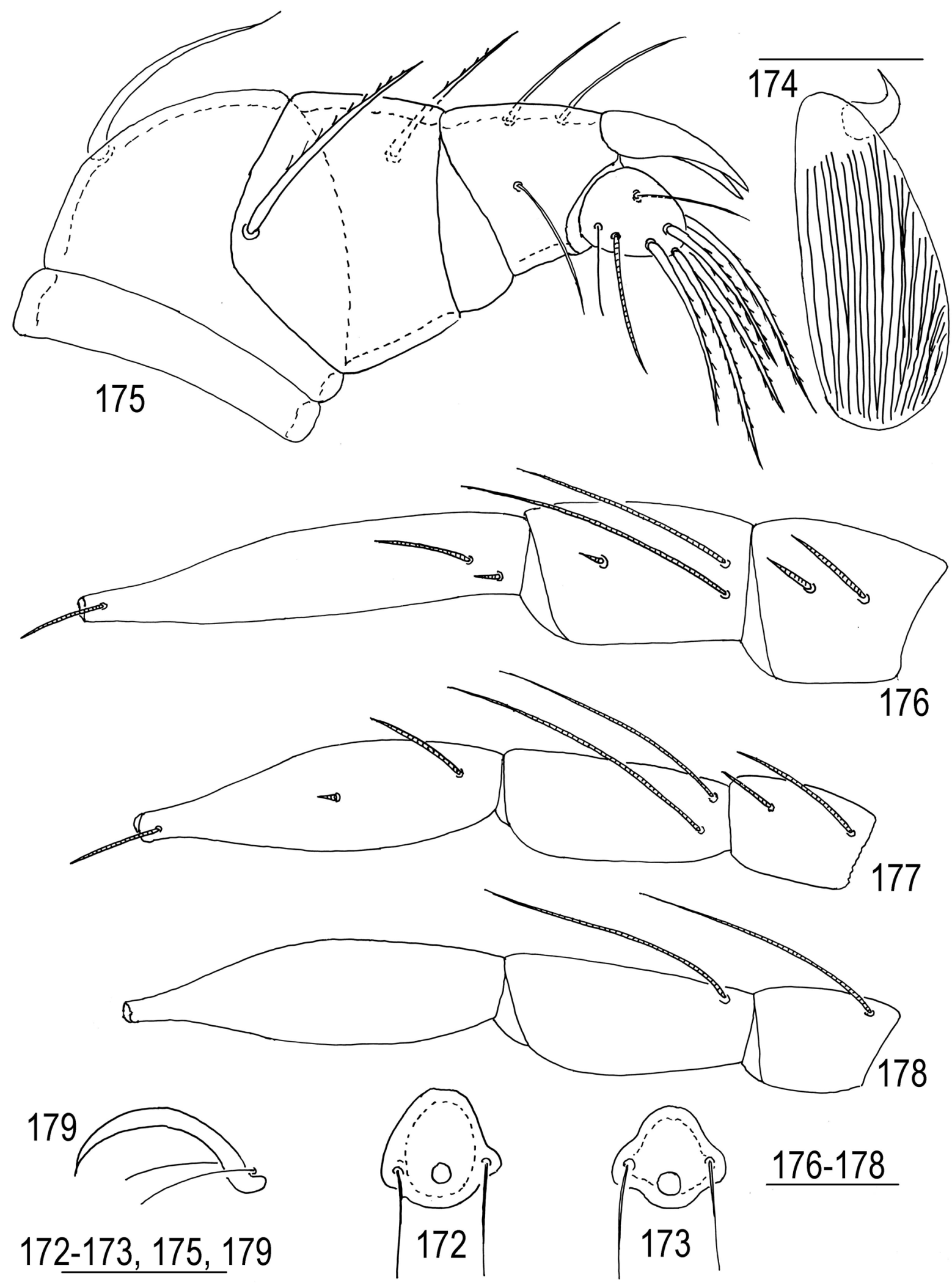

Figs. 172-179. Hydryphantes ruber (Geer, 1778), larva: 172-173 - excretory pore plate; 174 - chelicera, dorsal view; 175 - pedipalp, lateral view; 176-I-Leg-4-6; 177-II-Leg-4-6; 178-III-Leg-4-6; 179-claws of leg I. Simple setae on I-III-Leg-4-6 are not shown. Scale bars: $172-173,175,179,176-178=20 \mu \mathrm{m}, 174=50 \mu \mathrm{m}$.

Capitulum (Fig. 181) with equally convex basal part and moderately long rostrum (base of

capitulum/rostrum L ratio 3.0-4.5). 


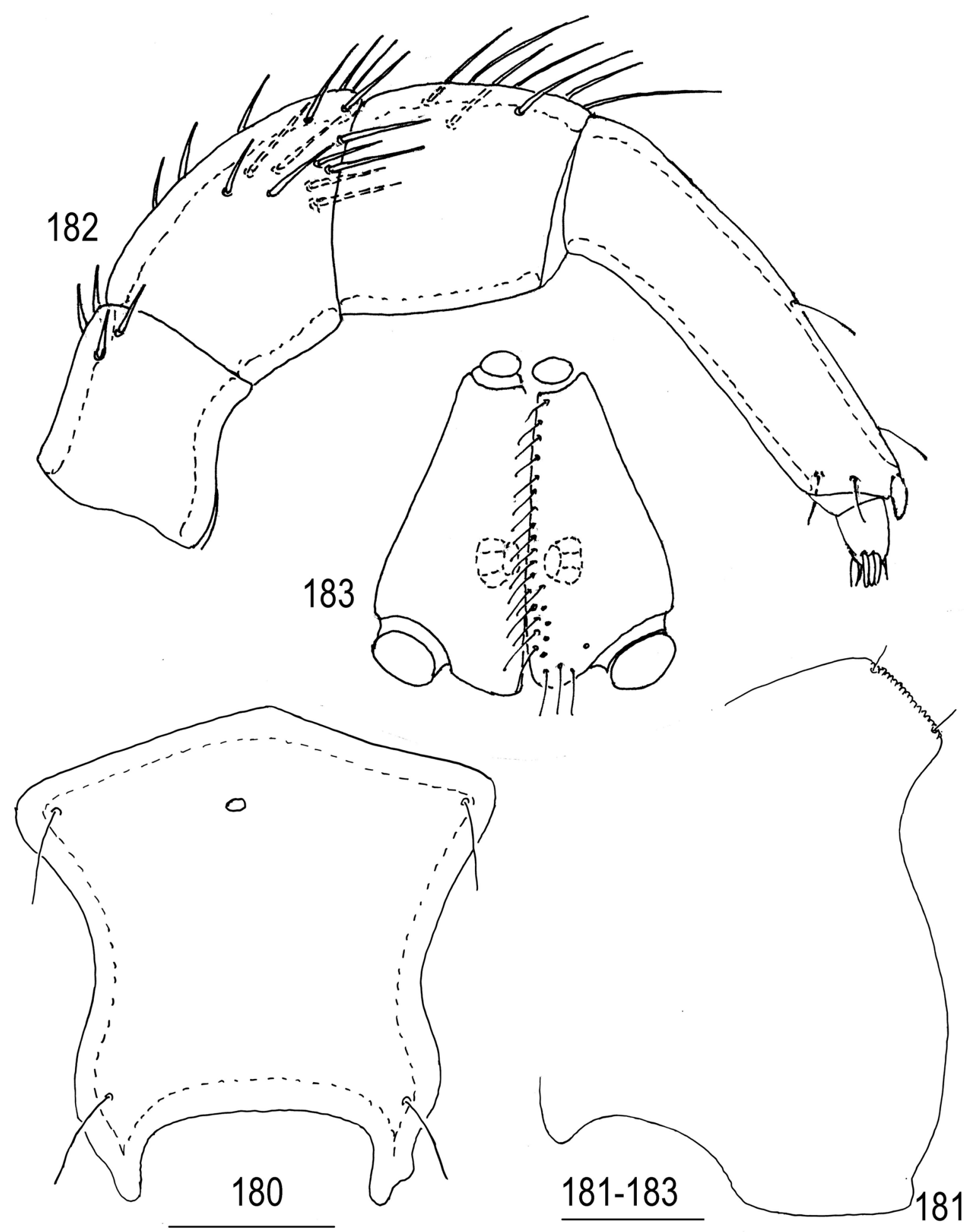

Figs. 180-183. Hydryphantes ruber (Geer, 1778), female: 180 — frontal plate; 181-capitulum, lateral view; 182pedipalp, lateral view; 183 -genital field. Scale bars: $180=200 \mu \mathrm{m} ; 181-183=100 \mu \mathrm{m}$.

Pedipalp slender (Fig. 182): P-1 with 3-5 dorsodistal setae; P-2 with 13-18 setae; P-3 with 4-7 setae; P-4 slender with three thin distal setae and short and thick dorsodistal spine.
Genital field with three pairs of acetabula, anterior pair of acetabula larger than second pair but slightly smaller than posterior pair of acetabula; acetabular plate elongate (L/W ratio 2.0-2.2), with 20-30 pairs setae (Fig. 183). 
Measurements, female $(\mathrm{n}=3)$. Idiosoma $\mathrm{L}$ 1650-2000; dorsal plate L 460-525, W 410-515; genital flaps L 275-340, W 125-140; genital acetabula (ac.1-ac. 3) D 50-55, 35-40, 60-68; capitulum L 350-415, rostrum L 90-115, basal segment of chelicera L 435-500, cheliceral stylet L 210-225; pedipalpal segments (P-1-5) L: 87-115, 135-165, 110-115, 245-255, 30-37; legs segments L: I-Leg-1-6: 110-125, 135-165, 185-200, 275290, 320-330, 325-340; II-Leg-1-6: 110-125,135$155,225-240,375-400,450-465,430-450$; IIILeg-1-6: 125-150, 135-165, 250-270, 400-450, 485-500, 460-500; IV-Leg-1-6: 235-275, 245260, 350-375, 560-590, 535-565, 460-515.

Remarks. Morphology of the American larvae of $H$. ruber differ from that the European larvae. In the American larvae of $H$. ruber the excretory pore plate wider than long, the excretory pore very large, P-4 with unequal thin setae (Prasad and Cook, 1972); while in the European larvae of this species the excretory pore plate usually as long as wide, the excretory pore small (Figs. 172-173), P-4 with subequal thin setae (Fig. 175). The American larvae of $H$. ruber probably belongs to other species or subspecies.

\section{Hydryphantes ruberoides Tuzovskij, 1990}

(Figs. 184-199)

Material examined. Six larvae were reared from single female, July 1981 (Chukotka). The duration of the embryonic period was 16 days.

Diagnosis. Larva. Distance between bases of trichobothria $O i$ usually equal their length, setae $F C h$ and $V i$ subequal; median eye situated between setae $V i$; all dorsal hysterosomal setae subequal; excretory pore plate wider than long; urstigma circular; P-5 solenidion longer of segment; I/IILeg-4 solenidion 1.5-2.0 times longer than eupathidium, I-Leg-5 with unequal solenidia, IILeg-5 with subequal solenidia; I-Leg- $6 d e<d s$.

Larva. Anterior pair of dorsal platelets oval (Fig. 184). Posterior plate slightly wider than long or slightly longer than wide (L/W ratio 0.94-1.07), narrows anteriorly and widens posteriorly; median eye slightly developed and situated between setae $\mathrm{Vi}$; distance between $\mathrm{Oi}-\mathrm{O} i$ usually equal their length, setae $F c h$ and $V i$ subequal; trichobothria $F p$ long and well extending to posterior tips of setae $\mathrm{Vi}$. Other dorsal setae $\mathrm{Oe}, \mathrm{Hi}, \mathrm{He}, \mathrm{Sci}$, Sce, $\mathrm{Li}$, and $L e$ subequal, their bases situated on very small sclerite.

Coxal plates II triangular with straight or slightly convex posterior margin, coxal plates I and

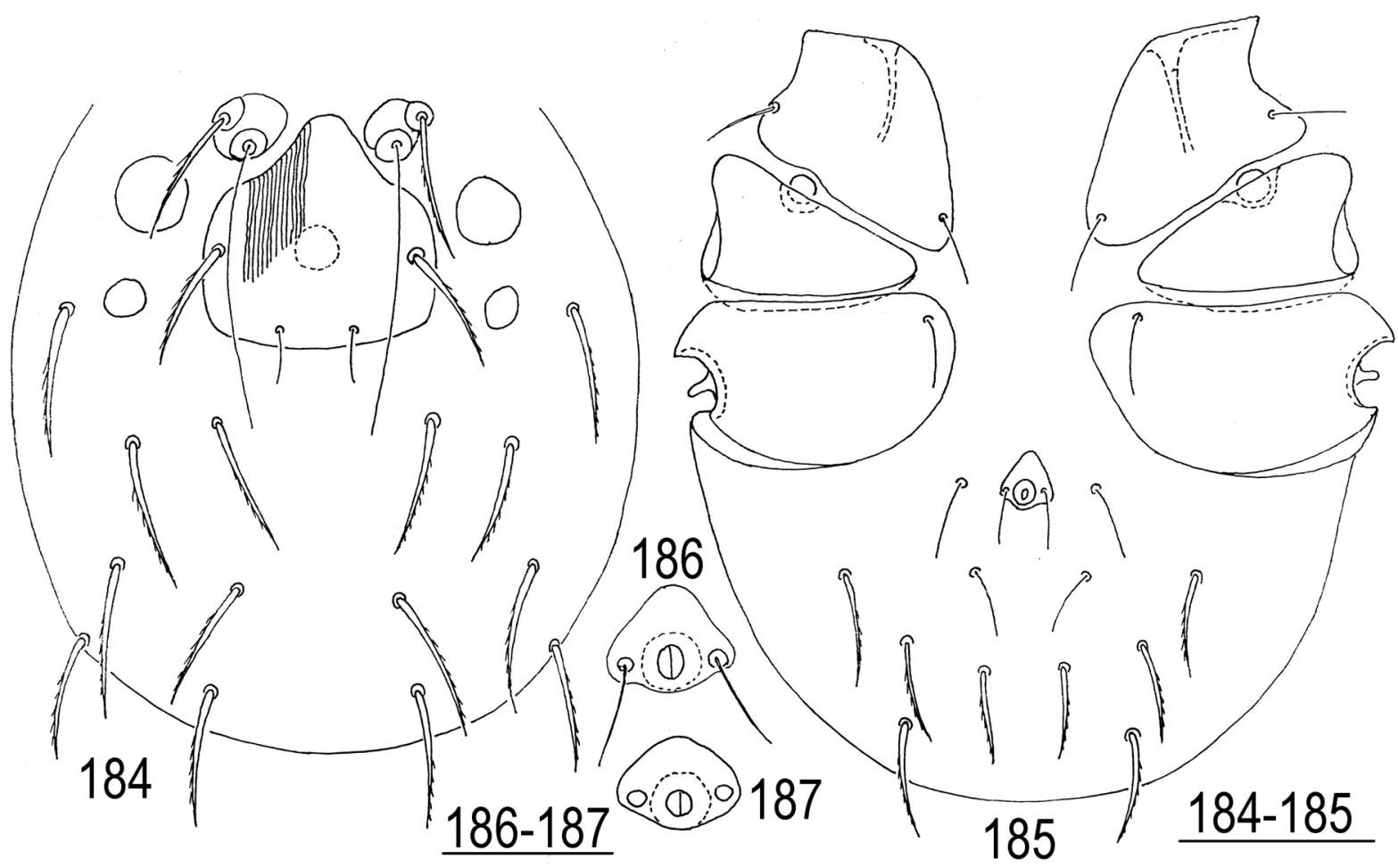

Figs. 184-187. Hydryphantes ruberoides Tuzovskij, 1990, larva: 184-dorsal view; 185-ventral view; 186-187excretory pore plate. Scale bars: $184-185=50 \mu \mathrm{m}, 186-187=20 \mu \mathrm{m}$. 

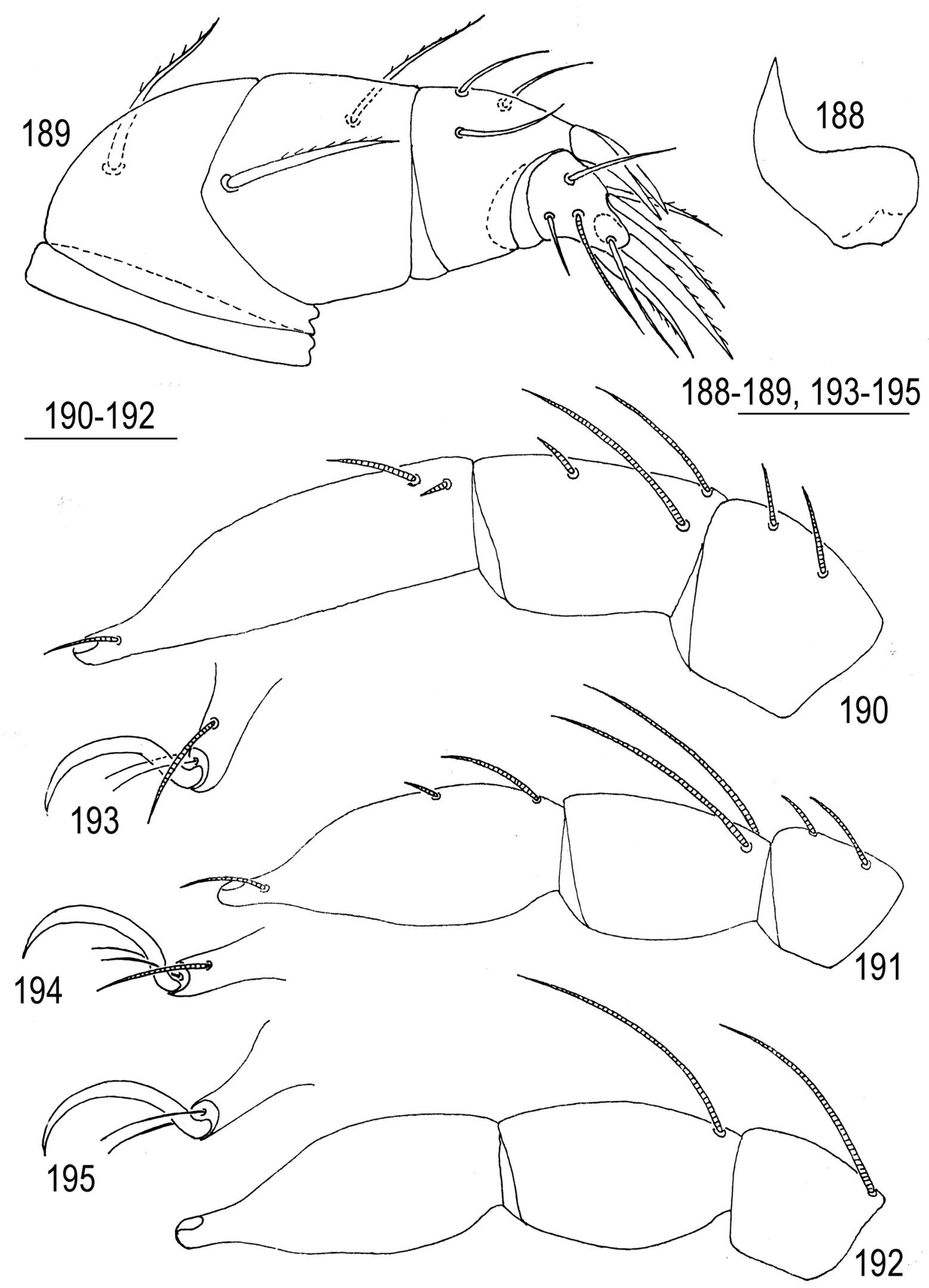

Figs. 188-195. Hydryphantes ruberoides Tuzovskij, 1990, larva: 188 - chela, lateral view; 189-pedipalp, lateral view; 190-I-Leg-4-6; 191-II-Leg-4-6; 192-III-Leg-4-6; 193 — claws of leg I; 194—claws of leg II, 195—claws of leg III. Simple setae on I-III-Leg-4-6 are not shown. Scale bars $=20 \mu \mathrm{m}$. 

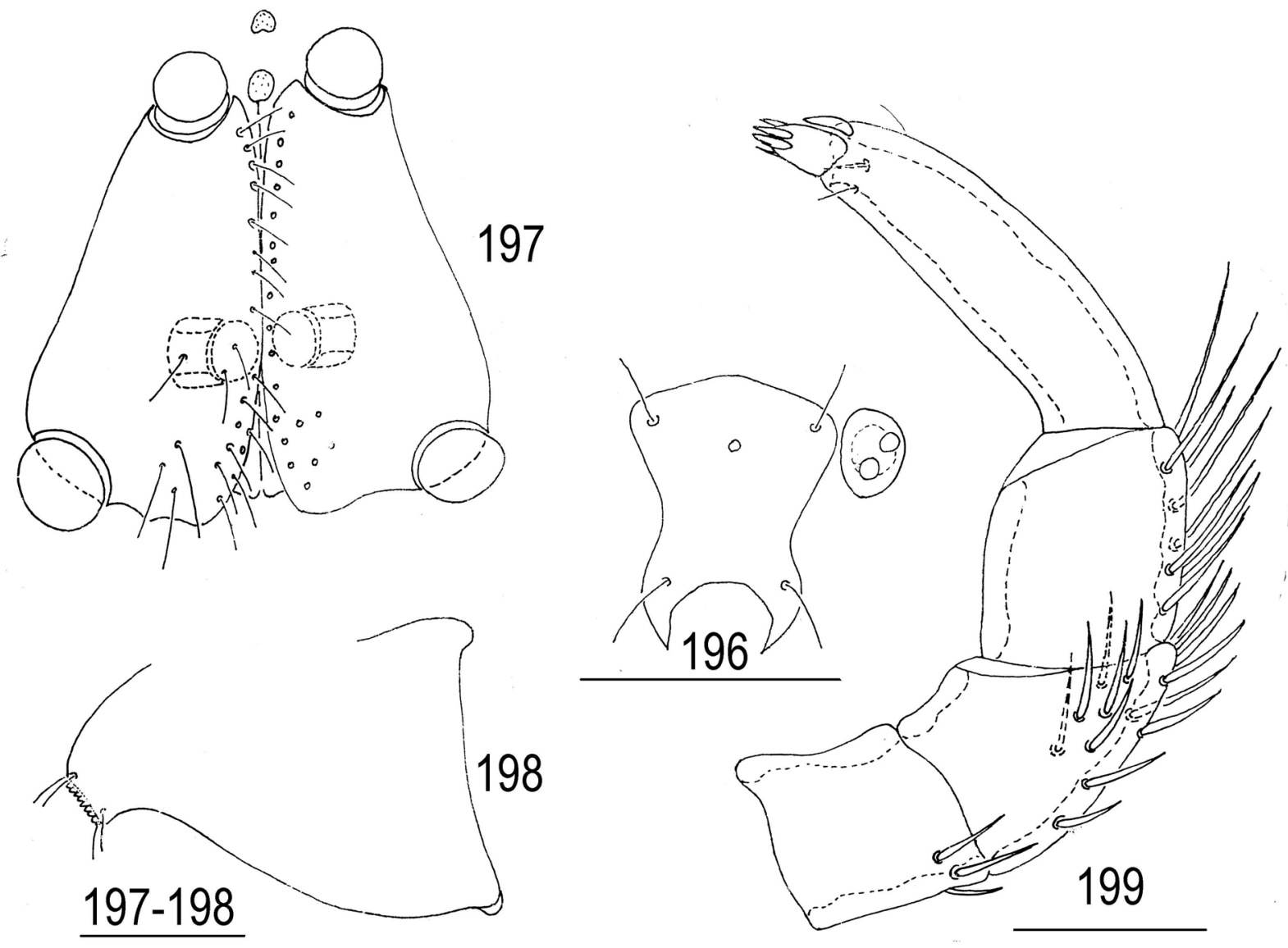

Figs. 196-199. Hydryphantes ruberoides Tuzovskij, 1990, female: 196-frontal plate; 197-genital field; 198capitulum, lateral view; 199—-pedipalp, lateral view. Scale bars: 196=200 $\mu \mathrm{m} ; 197-198,199=100 \mu \mathrm{m}$.

III more or less trapezoidal and broadly rounded medially, all coxal setae short and subequal (Fig. 185). Urstigma circular. Setae $\mathrm{Si}, \mathrm{Se}, \mathrm{Ci}$, and $\mathrm{Pi}$ subequal and slightly longer than both pairs of anal setae and $P e$. Excretory pore plate small, wider than long ( $\mathrm{L} / \mathrm{W}$ ratio $0.67-0.80$ ), its shape variable (Figs. 186-187).

Basal segment of chelicera large, with numerous thin strips, chela short (Fig. 188). Pedipalps stout (Fig. 189): P-2 large with convex dorsal margin and a single dorsoproximal seta; P-3 with two subequal setae (thick proximal and relatively thin distal); P-4 with three subequal setae and large dorsodistal claw with two subequal clawlets; P-5 small, with moderately long solenidion, five long and two short unequal simple setae.

Shape and arrangement of specialized setae on terminal legs segments as shown in Figs. 190-192. I/II-Leg-4 solenidion 1.5-2.0 times longer than eupathidium, I-Leg-5 with two unequal proximal solenidia and short distal eupathidium, I-Leg-6 $\mathrm{de}<\mathrm{ds}$; II-Leg-5 with subequal proximal solenidia,
III-Leg-4-5 with subequal proximal solenidion. Empodium large and crescent on all tarsi (Figs. 193-195), ambulacra I and II shorter than ambulacra III.

Measurements, $\mathrm{n}=6$. Dorsal plate L 47-51, $\mathrm{W}$ 48-51; setae Fch L 28-32, setae Fp L 68-75, setae Oi L 12-15, distance between setae Vi-Vi 41-44, distance between setae $\mathrm{Oi}-\mathrm{Oi}$ 21-23; excretory pore plate L 10-13, W 14-16; urstigma D 6-8; basal segments of chelicerae L 70-77, chela L 19-23; pedipalpal segments (P-1-5) L: 6-8, 28-32, 19-23, 19-23, 12-14; legs segments L: I-Leg-1-6: 25-29, 13-16, 16-18, 29-32, 35-41, 61-70; IILeg-1-6: 22-26, 10-16, 13-16, 19-23, 32-35, 55-58; III-Leg-1-6: 25-29, 16-19, 13-16, 22-24, 35-40, 51-55.

Female. Frontal shield slightly elongate (L/W ratio $1.05-1.15)$, anterolateral extensions slightly wider than posterolateral extensions, anterior margin obtuse-angled (Fig. 196) or slightly convex, posterior margin straight or concave, posterior projections comparatively short, their length equal 
to $1 / 3-1 / 4$ length of basal portion of plate. Median eye small and situated posterior to anterior setae.

Acetabular plate (Fig. 197) elongate (L/W ratio 2.0-2.3), with 15-25 pairs setae; posterior margin of plate nearly straight.

Capitulum (Fig. 198) with short rostrum (base of capitulum/rostrum L ratio 6.7-9.5) and convex ventral margin.

Pedipalp rather slender (Fig. 199): P-1 with 2-4 dorsodistal setae; P-2 with $8-18$ setae; P-3 with 3-9 setae; P-4 slender with three thin setae and short, thick dorsodistal spine.

Measurements ( $\mathrm{n}=8$ ). Idiosoma L 1435-1710; dorsal plate L 320-380, W 300-340; genital flaps L 210-270, W 90-140; genital acetabula (ac.1ac.3) D 42-48, 30-37, 54-66; capitulum L 250275, rostrum L 25-35; basal segment of chelicera L 300-325, chela L 115-125; pedipalpal segments (P-1-5) L: 70-78, 100-125, 78-85, 155-190, 23-25; legs segments L: I-Leg-1-6: 95-115, 150-170, 125-150, 185-230, 200-260, 210-265; II-Leg-1-6: 95-110, 165-185, 150-200, 245-325, 275-360, 275-355; III-Leg-1-6: 95-135, 150-190, 155-205, 270-330, 300-390, 275-385; IVLeg-1-6: 180-190, 210-235, 245-295, 365-430, $360-445,330-400$.

\section{Hydryphantes samaricus Tuzovskij, 2014}

(Figs. 200-216)

Material examined. 42 larvae were reared from four females (Yaroslavl Province). The duration of the embryonic period was 10-14 days.

Diagnosis. Larva. Distance between bases of trichobothria $O i$ larger than their length, setae $F c h$ and $V i$ subequal; all dorsal hysterosomal setae subequal; median eye situated between rows setae $V i$ and $O i$; chelicera with numerous thin strips; $\mathrm{P}-5$ with moderately long solenidion; I/II-Leg-4 solenidion longer than eupathidium; I/II-Leg-5 with subequal solenidia; I-Leg-6 $d e<d s$.

Larva. Anterior pair of platelets triangular or oval, trichobothria $F p$ long and a little extending to posterior margin of dorsal plate; setae $F c h$ and $V i$ subequal (Fig. 200). Posterior plate anteriorly narrow, posteriorly widening; median eye rather large and situated between setae $\mathrm{Vi}$; Oi short, distance between $\mathrm{Oi}-\mathrm{Oi}$ larger than their length. Other dorsal setae (Oe, Hi, He, Sci, Sce, $\mathrm{Li}$, and $\mathrm{Le}$ ) thick and subequal.

Coxal plates II triangular, coxal plates I and III more or less trapezoidal and rounded medially (Fig. 201); all coxal setae relatively short and subequal. Urstigma oval, wider than long. Setae Si longer and thicker than other ventral idiosomal setae. Setae $S e$, $\mathrm{Ci}, \mathrm{Pi}$ and $\mathrm{Pe}$ subequal and slightly longer and thicker than both pairs of anal setae $(A i, A e)$.

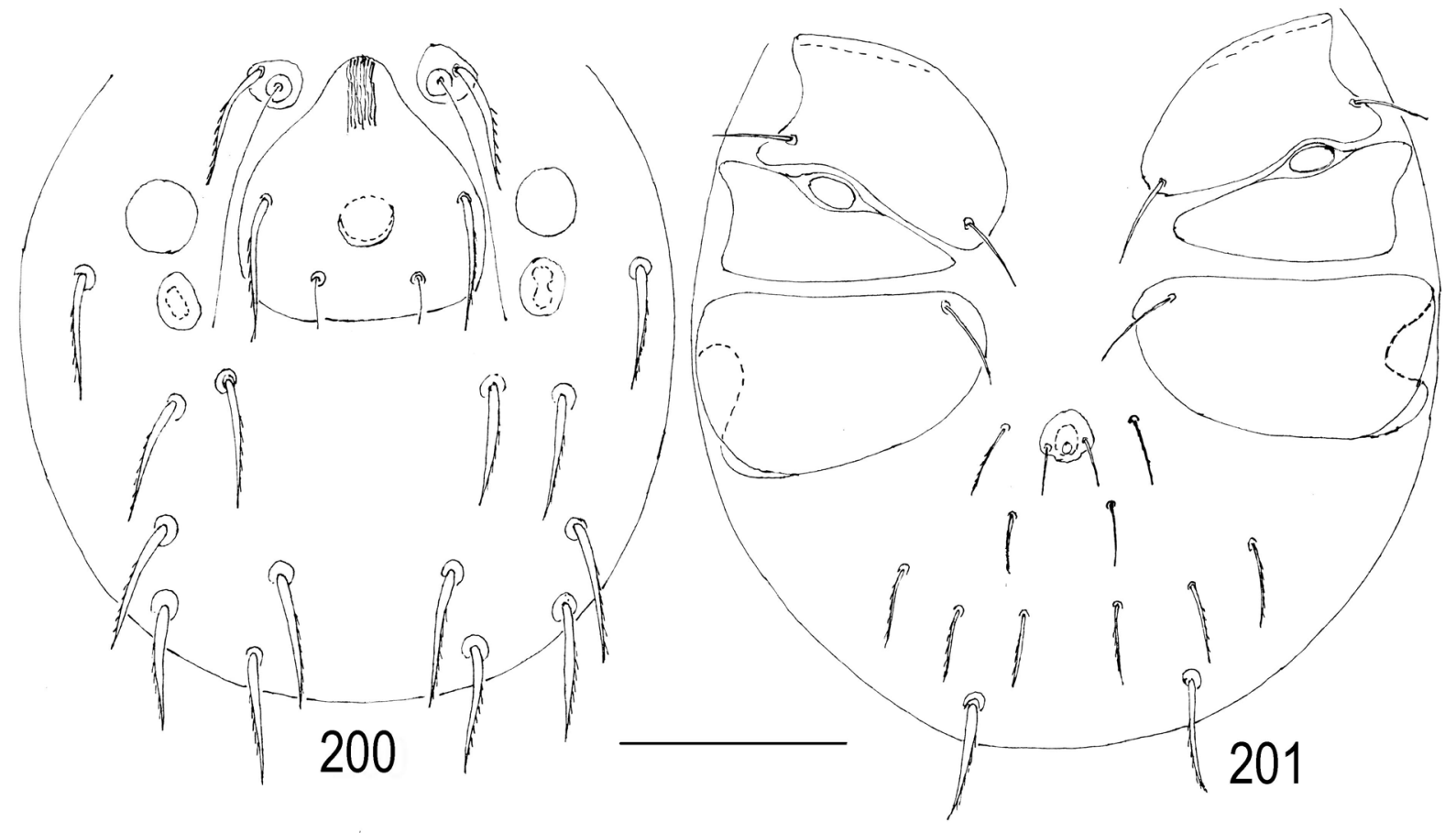

Figs. 200-201. Hydryphantes samaricus Tuzovskij, 2014, larva: 200_dorsal view; 202_ventral view. Scale bar: $50 \mu \mathrm{m}$. 


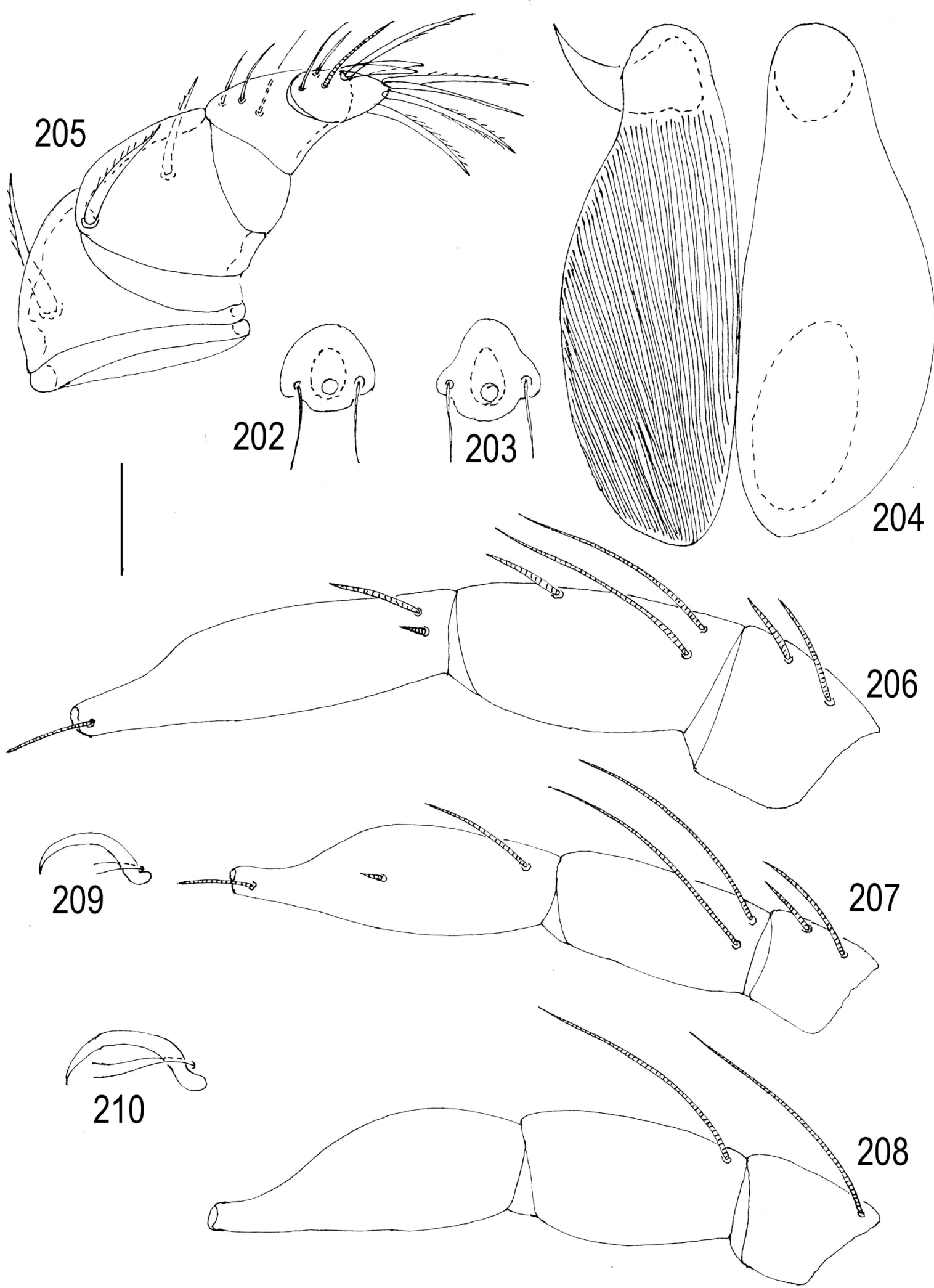

Figs. 202-210. Hydryphantes samaricus Tuzovskij, 2014, larva: 202-203-excretory pore plate; 204-chelicerae, dorsal view; 205-pedipalp, lateral view; 206-I-Leg-4-6; 207-II-Leg-4-6; 208-III-Leg-4-6; 209—claws of leg I, 210 - claws of leg III. Simple setae on I-III-Leg-4-6 are not shown. Scale bar=20 $\mu \mathrm{m}$.

Excretory pore plate small, usually wider than long or nearly as long as wide (L/W ratio $0.67-$
$0.95)$, excretory pore and bases of setae $A i$ located near posterior plate margin (Figs. 202-203). 


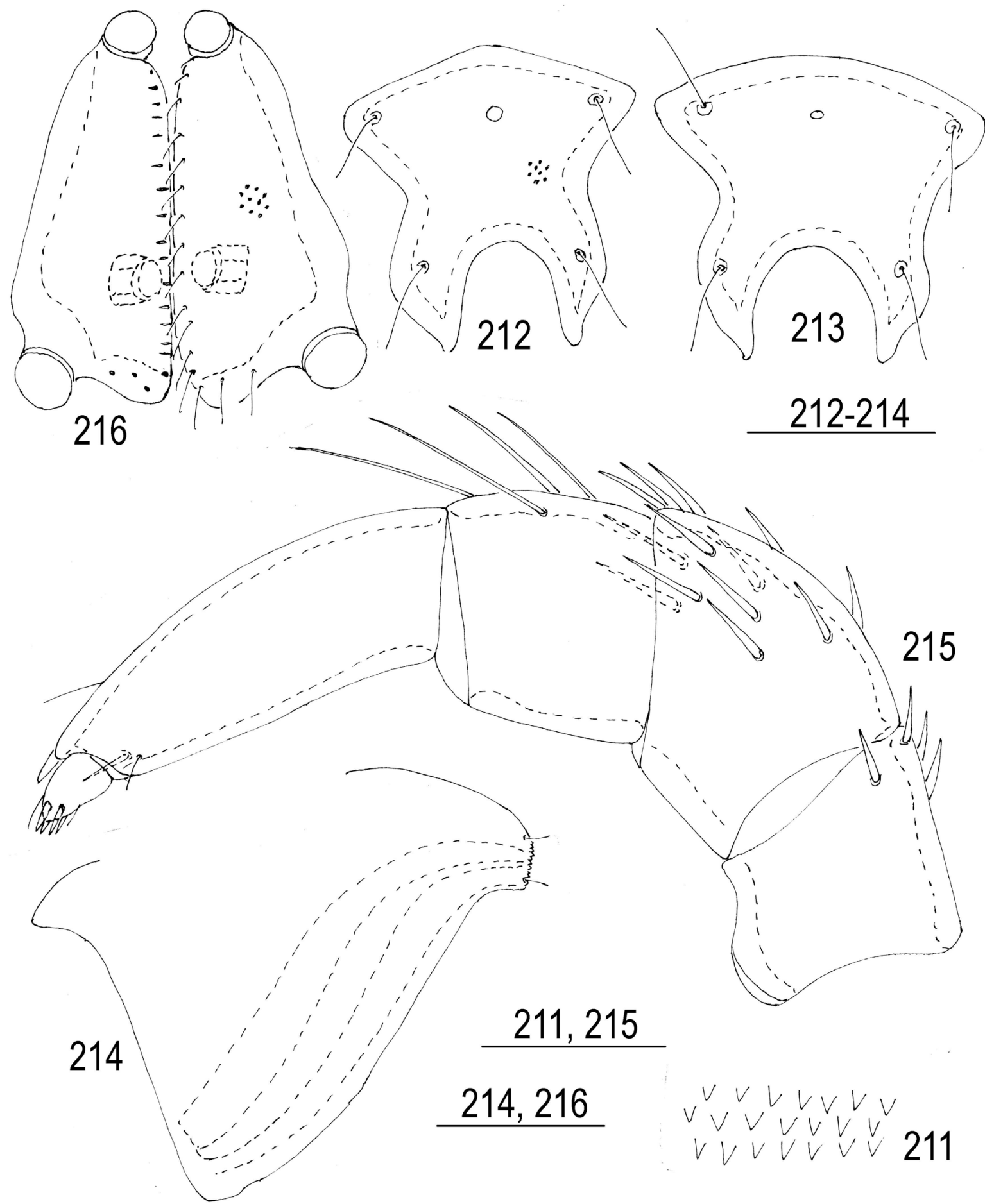

Figs. 211-216. Hydryphantes samaricus Tuzovskij, 2014, female: 211-fragment of integument; 212-213-frontal plate; 214 -capitulum; 215-pedipalp, 216-genital field. Scale bars: $211,215=50 \mu \mathrm{m}, 212-213=200 \mu \mathrm{m}, 214-$ $216=100 \mu \mathrm{m}$.

Chelicera (Fig. 204) with large basal segment and small chela. Basal segment with numerous thin strips.

Pedipalps stout (Fig. 205): P-1 very short and without setae; P-2 large, with convex dorsal margin and single proximal dorsal seta; P-3 with two subequal setae (proximal and distal); P-4 with three thin unequal setae, dorsodistal claw large with subequal clawlets; P-5 small, with a single moderately long solenidion and seven setae: five long and thick, two short and thin.

Shape and arrangement of specialized setae on terminal segments as shown in Figs. 206-208. I/IILeg-4 solenidion 1.5-2.0 times longer than eupathid- 
ium, I/II-Leg-5 solenidia subequal, I-Leg-6 eupathidium short and situated anteriorly to the solenidion basis; III-Leg-4-5 with subequal proximal solenidion. Empodium large and crescent-shaped on all tarsi, ambulacra short and thin (Fig. 209-210).

Measurements, $\mathrm{n}=10$. Dorsal plate L 35-40, W 38-42; setae Fch L 19-23, setae Fp L 40-45, setae $V i$ L 21-26, setae $O i$ L 6-9, setae Oe, Hi, He, Sci, $\mathrm{Sce}, \mathrm{Li}, \mathrm{Le}$, and $\mathrm{Si} \mathrm{L}$ 19-23; setae $\mathrm{Ci}, \mathrm{Se}, \mathrm{Pi}, \mathrm{Pe}$ 11-13; setae $A i$ and $A e$ 8-10; distance between setae $\mathrm{Vi}-\mathrm{Vi}$ 34-36, distance between setae $\mathrm{Oi}-\mathrm{Oi}$ 16-20; excretory pore plate L 6-8, W 9-11; urstigma L 6-7, W 9-10; basal segments of chelicerae L 57-61, chela L 11-13; pedipalpal segments (P-1-5) L: 6-7, 28-30, 15-17, 19-20, 11-13; leg segments L: I-Leg-1-6: 22-24, 12-13, 15-16, 22-24, 28-32, 47-49; II-Leg-1-6: 19-23, 10-13, 9-13, 14-16, 24-26, 36-39; III-Leg-1-6: 20-24, $11-15,11-13,14-16,27-29,35-39$.

Female. Integument with acute pointed papillae (Fig. 211). Frontal plate (Figs. 212-213) compact, with obtuse-angled or convex anterior margin, posterior margin concave, posterior projections rather long, median eye situated at level of anterior setae.

Capitulum (Fig. 214) with short rostrum, capitular base slightly convex.

Pedipalp stout (Fig. 215): P-1 with 3-4 short dorsodistal setae; P-2 with 10-14 short setae; P-3 usually with 4 (rarely 3 or 5 ) long dorsal setae; P-4 slightly tapering distally, with short dorsodistal spine and 3 thin distal setae.

Acetabular plate elongate (L/W ratio 1.9-2.2), with 15-18 medial (rarely present $1-2$ lateral) setae (Fig. 216).

Measurements $(\mathrm{n}=10)$. Idiosoma L 1100-1310; coxal plates I+II L 210-260, W 260-350; coxae III+IV L 285-375, W 285-350; genital plate L 185-215, W 90-112; capitulum L 210-240; chelicera L 325-340, chela L 115-125; pedipalpal segments (P-1-5) L: 62-75, 100-112, 60-75, 135-150, 20-26; leg segments L: I-Leg-1-6: 75-85, 90-115, 110-125, 160-175, 175-200, 200-215; II-Leg-1-6: 75-85, 85-100, 125-150, 210-240, 250-280, 260-290; III-Leg-1-6: 75-85, 100-115, 125-150, 210-225, 250-275, 260-290; IV-Leg-1-6: 150-165, 135-165, 190-240, 300-350, 300-350, 260-290.

Remarks. The larva of the present species is similar to the larva of $H$. planus. However, the following clear differences can be found in their morphology (character states of $H$. planus are given in parenthesis): the setae Fch shorter than Vi (subequal); I-Leg-4 solenidion longer than eupathidium (subequal); I-Leg-6 $d s>d e($ I-Leg-6 $d s=d e)$.

\section{Hydryphantes tenuipalpis Thor, 1899}

(Fig. 217-233)

Material examined. 22 larvae were reared from five females (Yaroslavl Province). The duration of the embryonic period was 10-15 days.

Diagnosis. Larva. Distance between bases of trichobothria $O i$ usually equal their length, setae $F c h$ shorter than $V i$; all dorsal hysterosomal setae subequal; excretory pore plate as long as or longer than wide; chelicera with very numerous thin strips; P-5 solenidion longer of segment; I-Leg-4 solenidion and eupathidium subequal in length; II-Leg-4 solenidion 2.5-3.0 times longer than eupathidium, I/II-Leg-5 with unequal solenidia, I-Leg- $6 d e<d s$.

Description. Anterior pair of platelets triangular or oval, trichobothria $F p$ long and extending to posterior margin of dorsal plate; setae $F c h$ shorter than $V i$ (Fig. 217). Median eye rather large and situated between rows setae $V i$ and $O i$; distance between $\mathrm{Oi}-\mathrm{O} i$ usually equal their length. Other dorsal setae (Oe, Hi, He, Sci, Sce, $\mathrm{Li}$, and $\mathrm{Le}$ ) thick and subequal.

Coxal plates II triangular, with straight or slightly convex posterior margin; coxal plates I and III more or less trapezoidal and rounded medially (Fig. 218); all coxal setae relatively short and subequal. Urstigma rather large, wider than long. Setae $\mathrm{Si}$ longer and thicker than other ventral idiosomal setae. Setae $\mathrm{Se}, \mathrm{Ci}, \mathrm{Pi}$, and $P e$ subequal and slightly longer and thicker than anal setae $(A i, A e)$.

Excretory pore plate small, its shape variable (Figs. 219-222). Excretory pore posterior to setae $A i$ in posterior portion of the plate. Setae $A i$ and $A e$ subequal.

Chelicera (Fig. 223) with large basal segment and small chela. Basal segment with numerous thin strips.

Pedipalps stout (Fig. 224): P-2 large with convex dorsal margin and single dorsoproximal setae; P-3 with two subequal setae (proximal and distal); P-4 with three thin unequal setae, dorsodistal claw large with subequal clawlets; P-5 solenidion longer of segment.

Shape and arrangement of specialized setae on terminal segments as shown in Figs. 225-227. ILeg-4 solenidion and eupathidium nearly subequal in length, II-Leg-4 solenidion 2.5-3.0 times longer than eupathidium, I/II-Leg-5 proximal solenidia unequal; I-Leg-6 de $<$ ds; III-Leg-4-5 with subequal proximal solenidion. Empodium large and crescentshaped on all tarsi, ambulacra short and thin (Figs. 228-229). 

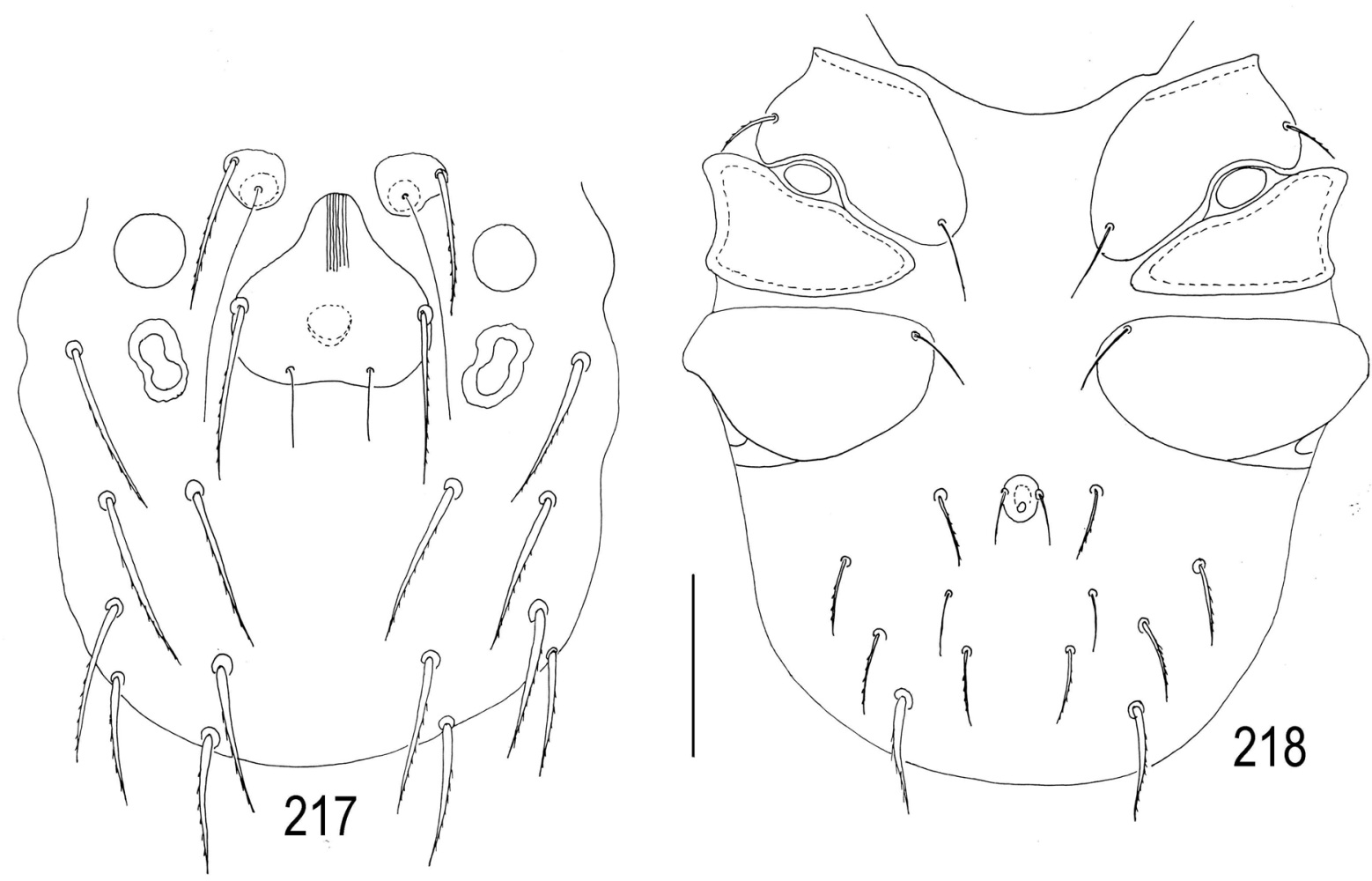

Figs. 217-218. Hydryphantes tenuipalpis Thor, 1899, larva: 217—dorsal view; 218 — ventral view. Scale bar: $50 \mu \mathrm{m}$.

Measurements, $\mathrm{n}=10$. Dorsal plate L 37-44, W 45-50; setae Fch L 28-30, setae Fp L 65-72, setae Vi L 36-47, setae Oi L14-25, setae Oe, Hi, He, Sci, $\mathrm{Sce}, \mathrm{Li}$, Le and $\mathrm{Si}$ L 32-44; setae $\mathrm{Ci}$, Se, Pi, Pe 21-25; setae $A i$ and $A e$ 16-20; distance between setae $\mathrm{Vi}-\mathrm{Vi} 41-44$, distance between setae $\mathrm{Oi}-\mathrm{Oi}$ 15-25; excretory pore plate L 10-13, W 10-14; urstigma L 6-8, W 11-13; basal segments of chelicerae L 85-92, chela L 22-25; pedipalpal segments (P-1-5) L: 6-8, 31-38, 31-35, 18-20, 11-14; leg segments L: I-Leg-1-6: 26-34, 20-24, 18-22, 31-38, 38-42, 75-82; II-Leg-1-6: 25-28, 20-25, 13-15, 21-27, 33-40, 57-67; III-Leg-1-6: 27-30, 20-22, 15-18, 23-28, 40-44, 61-72.

Female. Integument with short rounded papillae. Frontal plate (Fig. 230) subquadrate, with obtuse-angled or convex anterior margin, posterior margin straight or slightly concave, posterior projections short, median eye posterior to anterior setae.

Capitulum (Fig. 231) with moderately long rostrum, length equal to $1 / 3-1 / 5$ of length capitulum.

Pedipalp rather slender (Fig. 232): P-1 with 3-5 short dorsodistal setae; P-2 with 15-20 short setae; P-3 with 9-13 dorsal setae; P-4 slender, usually with two dorsal submedial setae, three thin distal setae, and short, thick dorsodistal spine.

Acetabular plate elongate (L/W ratio 2.1-2.2), with 16-22 medial setae (Fig. 233).
Measurements $(\mathrm{n}=9)$. Idiosoma L 1800-2500; frontal plate L 535-615, W 535-625, genital plate L 275-325, W 125-150; capitulum L 385-440; chelicera L 680-715, chela L 260-290; pedipalpal segments (P-1-5) L: 110-125, 160-175, 125-140, 275-300, 30-40; leg segments L: I-Leg-1-6: 135-165, 185-225, 225-250, 280-365, 375-415, 375-400; II-Leg-1-6: 135-150, 185-200, 260-315, 450-490, 535-575, 510-540; III-Leg-1-6: 150165, 185-200, 285-315, 485-515, 535-600, 510-550; IV-Leg-1-6: 275-300, 225-325, 410475, 650-690, 600-650, 510-565.

Remarks. Hydryphantes tenuipalpis was originally described as a form or subspecies of $H$. ruber and was cited as subspecies in many papers (Viets 1919, 1928, 1936, 1956; Laska 1962; Szalay 1964; etc) or, subsequently, as species (Lundblad 1962, 1968; Biesiadka 1972; Qzkan 1982; K. O. Viets 1978, 1987; Gerecke 1996). H. tenuipalpis was only known from adults. The morphology of larvae and deutonymphs of $H$. tenuipalpis (Tuzovskij 2008) clear differs from that of $H$. ruber, and $H$. tenuipalpis should be treated as a separate species. 

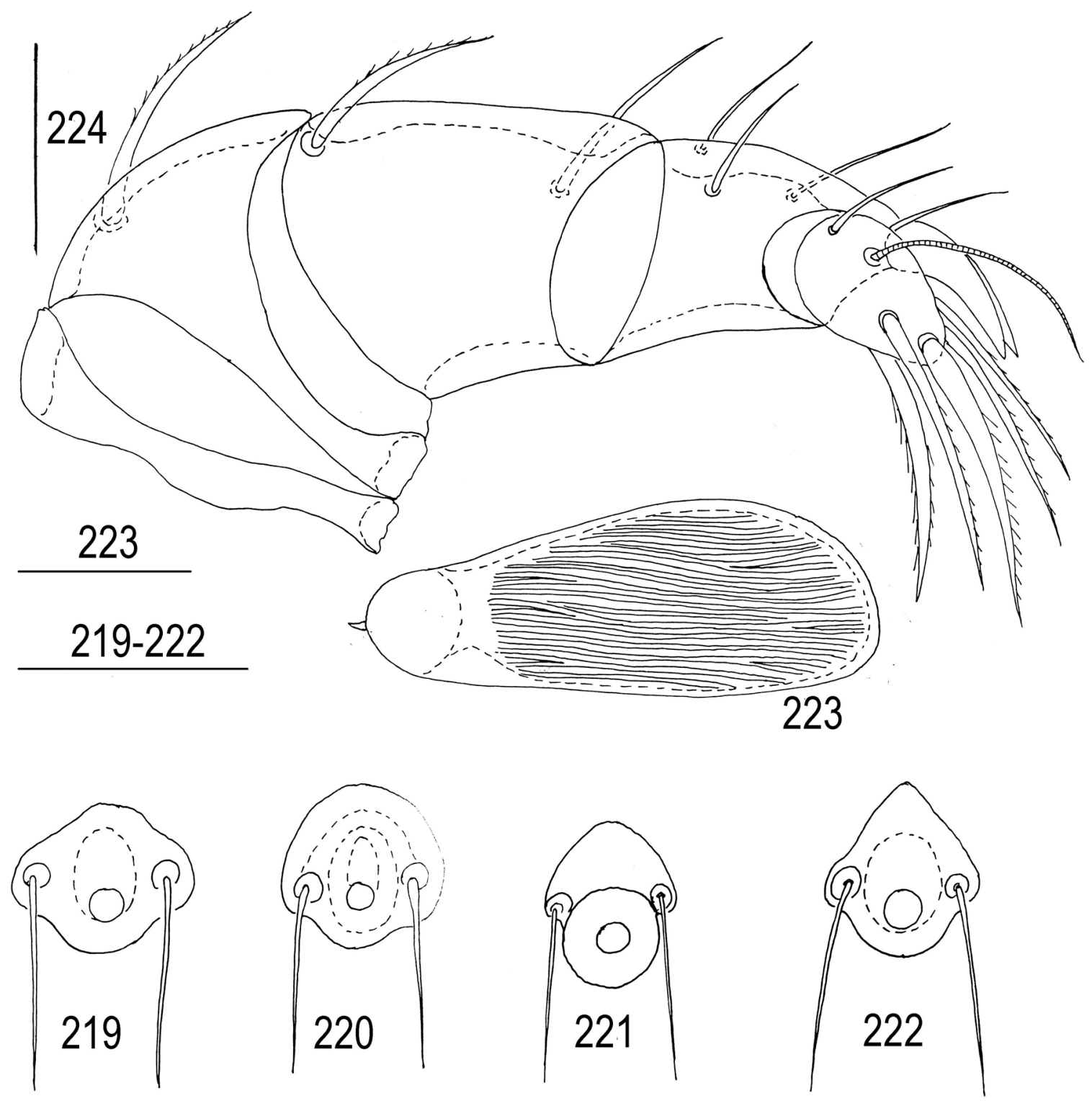

Figs. 219-224. Hydryphantes tenuipalpis Thor, 1899, larva: 219-222 —excretory pore plate; 223 — chelicera, dorsal view; 224 - pedipalp, lateral view. Scale bars $=20 \mu \mathrm{m}$.

\section{Key to Hydryphantes species from Russia}

\section{Larvae}

1 (2) Internal dorsal hysterosomal setae $(\mathrm{Hi}$, $\mathrm{Sci}, \mathrm{Li}$ ) longer than external setae (He, Sce, Le) (Fig. 24) H. dispar (Schaub, 1888) length

2 (1) All dorsal hysterosomal setae subequal in

3 (4) P-4 dorsodiastal claw with clearly unequal clawlets (Fig. 128) .... H. placationis Thon, 1899

4 (3) P-4 dorsodiastal claw with subequal clawlets

5 (8) Setae $O i$ long, distance between them shorter than their length

6 (7) Median eye situated between rows setae $V i$ and $\mathrm{Oi}$ (Fig. 85), bases of setae $A i$ situated near middle of the excretory pore plate (Figs. 87-88); I-IIILeg-6 relatively short: $63-69 \mu \mathrm{m}, 53-60 \mu \mathrm{m}, 50-55$ $\mu \mathrm{m}$, respectively ..........H. nonundulatus Thon, 1899

7 (6) Median eye situated between setae Vi (Fig. 170), bases of setae $A i$ situated in the posterior portion of the excretory pore plate (Figs. 172-173); I-III-Leg-6 long: 72-76 $\mu \mathrm{m}, 63-65 \mu \mathrm{m}, 60-63 \mu \mathrm{m}$, respectively H. ruber (Geer, 1778)

8 (5) Setae $O i$ comparatively short, distance between them equal or larger than their length

9 (10) Distance between setae $O i$ equal their length (Fig. 217) ......... H. tenuipalpis Thor, 1899

10 (9) Distance between setae $O i$ larger their length

11 (16) I-Leg-4 solenidion and eupathidium subequal in length 


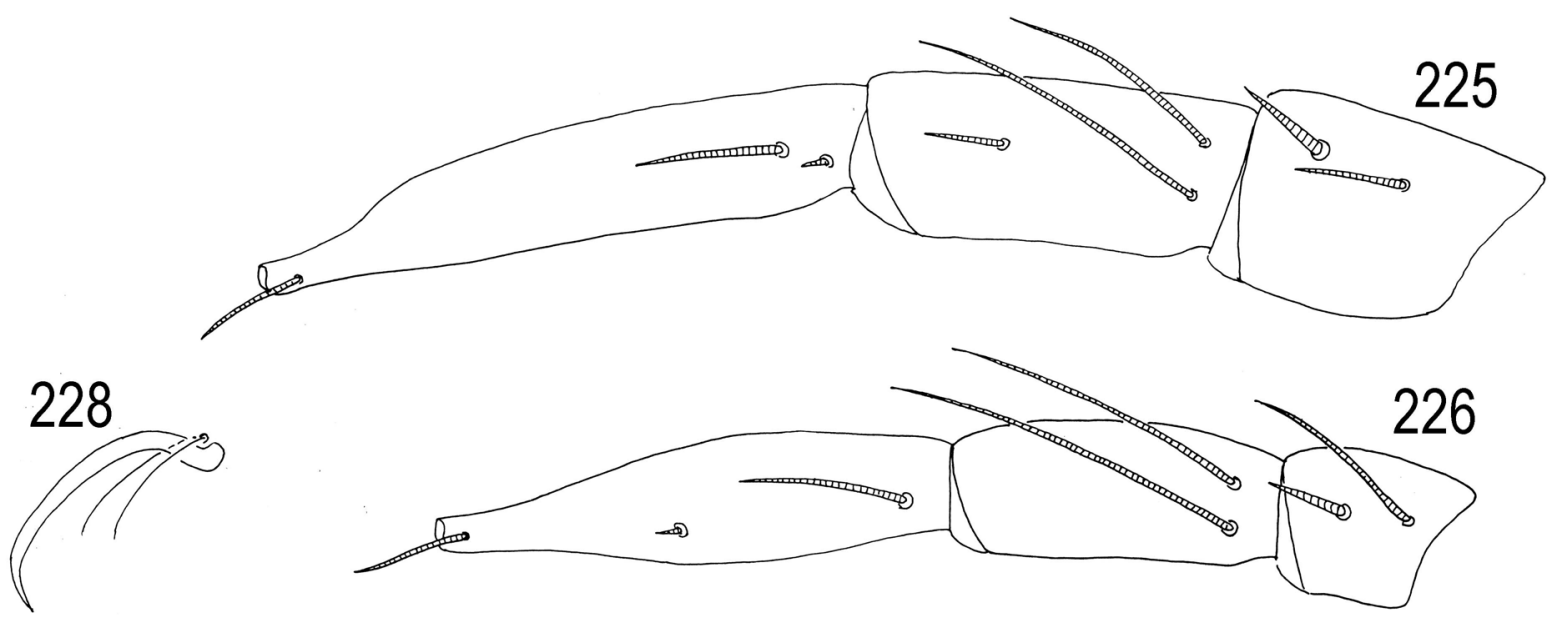

$\underline{228-229}$

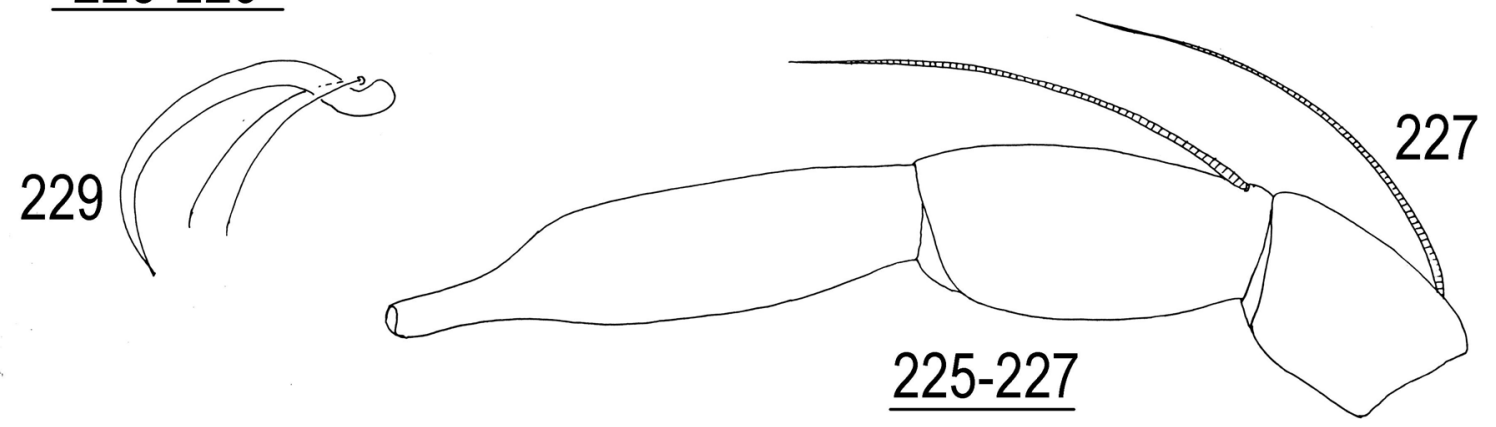

Figs. 225-229. Hydryphantes tenuipalpis Thor, 1899, larva: 225-I-Leg-4-6; 226-II-Leg-4-6; 227-III-Leg-4-6; 228 - claws of leg I, 229 — claws of leg III. Simple setae on I-III-Leg-4-6 are not shown. Scale bars=20 $\mu \mathrm{m}$.

12 (13) Basal segment of chelicera with a few wide strips (Fig. 56) ...... H. hellichi Thon, 1899

13 (12) Basal segment of chelicera with numerous narrow strips

14 (15) P-3 long (26-28 $\mu \mathrm{m})$, P-4 with three unequal thin setae, P-5 solenidion longer of segment (Fig. 74) .......... H. ildensis Tuzovskij, 2016

15 (14) P-3 short (16-19 $\mu \mathrm{m})$, P-4 with three subequal thin setae, P-5 solenidion shorter of segment (Fig. 144) H. planus Thon, 1899

16 (11) I-Leg-4 solenidion distinctly longer than eupathidium

17 (18) I-Leg-6 ds1<de1 (Fig. 111) H. octoporus Koenike, 1896

18 (17) I-Leg-6 ds $1>$ de 1

19 (20) P-5 solenidion shorter of segment (Fig. 23) H. crassipalpis Koenike, 1914

20 (19) P-5 solenidion equal or longer of segment

21 (22) P-5 solenidion equal of segment length (Fig. 205) H. samaricus Tuzovskij, 2014

22 (21) P-5 solenidion longer of segment

23 (24) I/II-Leg-4 solenidion 3-4 times longer than eupathidium (Figs. 160-161) H. prolongatus Thon, 1899
24 (23) I/II-Leg-4 solenidion 1.5-2.5 times longer than eupathidium

25 (26) Urstigma oval (Fig. 2), II-Leg-5 proximal solenidia unequal (Fig. 9), II/III-Leg-6 short: $46-50 \mu \mathrm{m}$ and $45-48 \mu \mathrm{m}$, respectively ......

H. clypeatus (Thor, 1899)

26 (25) Urstigma circular (Fig. 185), II-Leg-5 proximal solenidia subequal (Fig. 191), II/III-Leg-6 relatively long: $55-58 \mu \mathrm{m}$ and $51-55 \mu \mathrm{m}$, respectively H. ruberoides Tuzovskij, 1990

\section{Females}

1 (2) Genital field with four to six pairs of acetabula (Subgenus Polyhydryphantes) (Figs. 120-122) H. octoporus Koenike, 1896

2 (1) Genital field with three pairs acetabula (Subgenus Hydryphantes)

3 (4) Integument papillae acute pointed (Fig. 211) H. samaricus Tuzovskij, 2014

4 (3) Integument papillae rounded distally

5 (6) Frontal plate (Fig. 63) elongate (L/W L ratio $>1.3)$ H. hellichi Thor, 1899

6 (5) Frontal plate as long as wide or slightly longer than wide $(\mathrm{L} / \mathrm{W}$ L ratio $<1.2)$ 


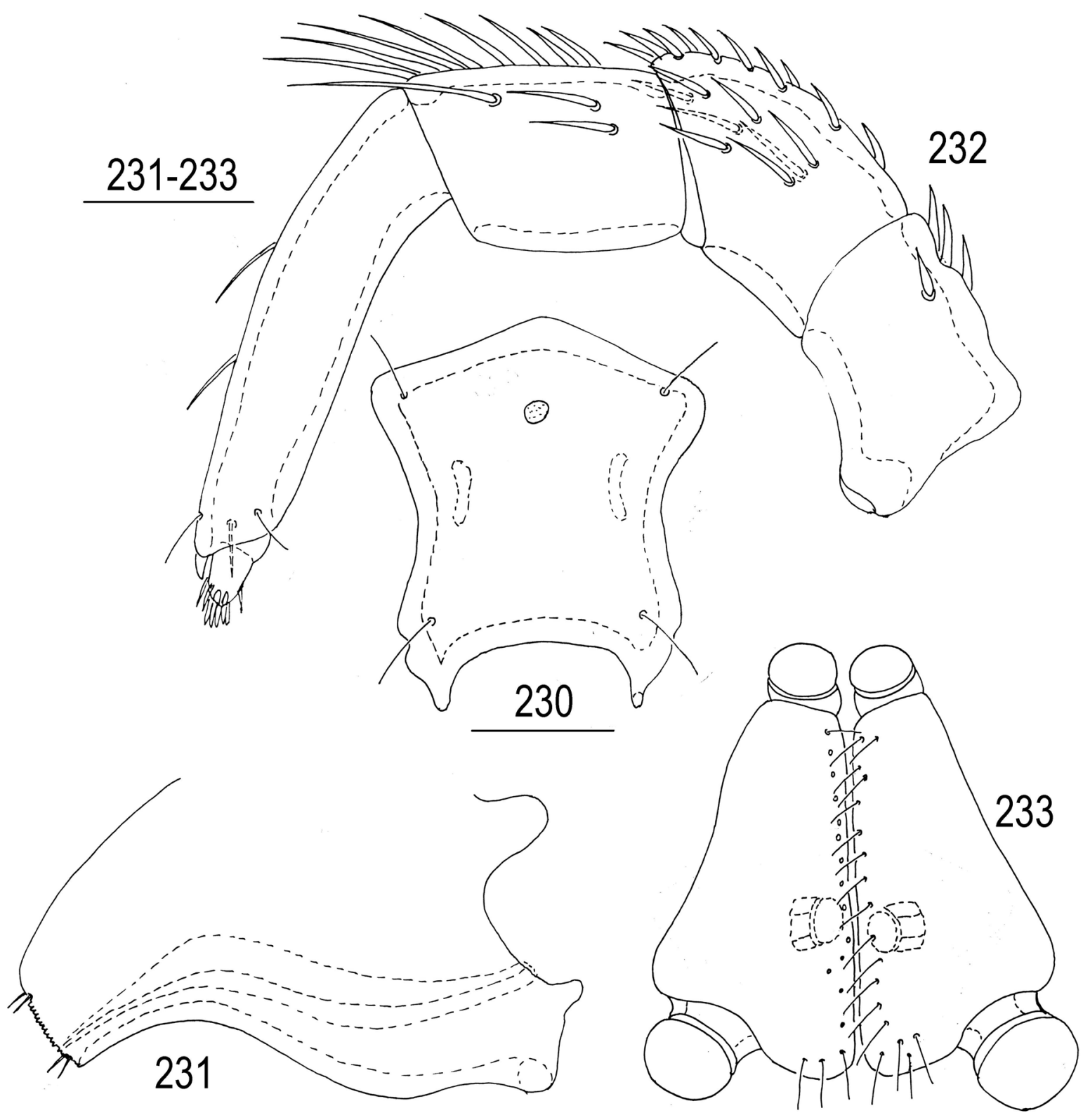

Figs. 230-233. Hydryphantes tenuipalpis Thor, 1899, female: 230-frontal plate; 231-capitulum; 232-pedipalp, lateral view; 233-genital field. Scale bars: $230=200 \mu \mathrm{m}, 231-233=100 \mu \mathrm{m}$.

7 (8) Frontal plate anteriorly and posteriorly equal in width (Fig. 13) .. H. clypeatus (Thor, 1899)

8 (7) Frontal plate anteriorly broader than at the posterior ends

9 (12) Frontal plate with long posterior projections, their length and median plate length subequal

10 (11) Frontal plate anteriorly protrusion in an obtuse angle (Fig. 45), ac-3 moderately in size, $\mathrm{D}=60-65 \mu \mathrm{m}$ (Fig. 47) ...H. dispar (Schaub, 1888)

11 (10) Frontal plate anteriorly hardly protrusion (Fig. 135), ac-3 comparatively large $\mathrm{D}=85$ 90 H. placationis Thon, 1899

12(9) Frontal plate with short posterior projections, their length much shorter than median plate length
13 (20) Capitulum with relatively long rostrum, its length two to four times shorter than capitular base length

14 (15) Frontal plate anteriorly distinctly broadly than posteriorly (Fig. 165)

H. prolongatus Thon, 1899

15 (14) Frontal plate anteriorly only slightly broadly than posteriorly

16 (17) P-3 with four setae (Fig. 102) H. nonundulatus Thon, 1899

17 (16) P-3 with 5-15 setae

18 (19) Chelicera with long chela (L 260-290 $\mu \mathrm{m})$ and P-4 (L 275-300 $\mu$ )

H. tenuipalpis Thor, 1899 
19 (18) Chelicera with comparatively short chela (L 210-225 $\mu \mathrm{m}$ ) and P-4 (L 245-255 $\mu \mathrm{m})$.. H. ruber (Geer, 1778)

20 (13) Capitulum with short rostrum, its length five to ten times shorter than capitular base

21 (22) Pedipalp extremely robust (Fig. 33) .. H. crassipalpis Koenike, 1914

22 (21) Pedipalp more slender

23 (24) Frontal plate subquadrate (Fig. 149), medial plate /posterior projections L ratio 4.04.65 ................................ H. planus Thon, 1899

24 (23) Frontal plate elongate, medial plate / posterior projections $\mathrm{L}$ ratio $<3.5$

25 (26) Frontal plate large (L $485 \mu \mathrm{m})$, genital field (Fig. 82) with 32-50 pairs of setae

H. ildensis Tuzovskij, 2016

26 (25) Frontal plate comparatively small (L 320-380 $\mu \mathrm{m}$ ), genital field (Fig. 197) with 15-25 pairs of setae ...... H. ruberoides Tuzovskij, 1990

\section{ACKNOWLEDGEMENTS}

The author expresses his sincere gratitude to anonymous referees for their careful work and critical comments.

\section{REFERENCES}

Biesiadka, E. 1972. Wodppojki (Hydracarina) Wielkopolkiego Parku Narodowego. Prace Monograf.nad Przyroda Wielkopolskiego Parku pod Poznaniem, 5(3): 1-103.

Biesiadka, E. and Cichocka, M. 1990. Studies on the morphology of larval stages of water mites (Hydracarina) 2. Some species of the superfamily Hydryphantoidea. Annales Zoologici, 43(24), 461-492.

Di Sabatino, A., Gerecke, R., Gledhill, T., and Smit, H. 2009. On the taxonomy of water mites (Acari: Hydrachnidia) described from the Palaearctic, part 2. Hydryphantoidea and Lebertioidea. Zootaxa, 2266, 1-34.

Di Sabatino, A., Gerecke, R., Gledhill, T., and Smit, H. 2010. 8. Acari, Hydrachnidia II. In: R. Gerecke (Ed). Süßwasserfauna von Mitteleuropa, 7/2-2, Spectrum Akademischer Verlag Heidelberg: 1-234.

Gerecke, R. 1996. Untersuchungen über Wassermilben der Familie Hydryphantidae (Acari, Actinedida) in der Westpalaearktis, II. Die Wassermilben der Familie Hydryphantidae Piersig, 1896 in der Mittelmeerländern. Archiv für Hydrobiologie, Supplementband, 77(3-4): 337-513.

Imamura T. 1954. Studies on Water-Mites from Hokkaido. Journal Hokkaido Gakugei University, Sect. B., Supplement 1: 1-148.
Koenike, 1908. Beitrag zur Kenntnis der Hydrachniden. Abhandlungen des Naturwissenschaftlichen Vereins Bremen, 19(2): 217-266.

Láska, F. 1964. Über einige seltene stagnicole, für die Slowakei neue Wassermilben (Hydrachnellae, Acari). Biologia, 19(12): 920-935.

Lundblad, O. 1962. Die Hydracarinen Schwedens. II. Arkiv för Zoology, 14(1-6): 1-635.

Lundblad, O. 1968. Die Hydracarinen Schwedens. III. Arkiv för Zoology, 21(6): 1-633.

Özkan, M. 1982. Dogu Anadolu Bölgesi suAkarlari (Acari, Hydracnellae) zerine sistematik Arastirmalar-II. Atatürk Üniv. Fen. Fak. Der. Cilt. 1,Özel Sayi, 1: 145-163.

Piersig, G. R. 1897-1900. Deutschlands Hydrachniden. Zoologica. Stuttgart, 19(22), I-VII+1-601+51 Taf.

Prasad V. and Cook D. R. 1972. The taxonomy of water mite larvae. Memoirs of the American Entomological Institute, 18: 1-326.

Smith, I. M. and Oliver, D. R. 1986. Review of parasitic associations of larval water mites (Acari: Parasitengona: Hydrachnida) with insect hosts. The Canadian Entomologist, 118: 407-472.

Soar and Williamson. 1925. The British Hydracarina. Vol. I. London, Ray Society, 110, 10+215+40 pp.

Sokolow, I. I. 1940. Hydracarina-vodyanye kleshchi. Chast' I. Hydrachnellae. Fauna SSSR (novaya seriya No 20. Paukoobraznye, 5(2) [Hydracarina - the aquatic mites. Part I. Hydrachnellae]. Nauka, Moscow-Leningrad, 24 pp.+511. [In Russian]

Sparing, I. 1959. Die Larven der Hydrachnellae, ihre parasitische Entwicklung und ihre Systematik. Parasitol. Scriftenreihe. Jena, 10, 168 pp.

Stiller, J. 1960. Die limnologischen Verhältnisse des Naturschutzgebietes von Bátorliget in Ungarn nebst Beschreibung einiger neuer Peritrichen-Arten (Ciliata, Protozoa). Archiv für Hydrobiologie, 56(3): 186-260.

Stolbov, V. A. 2010. [Taxonomic composition and biotopic distribution of water mites (Acariformes: Hydrachnidia) in various water bodies of the Tyumen region]. Vestnik of Tyumen University, 7: 101-107 [In Russian].

Szalay, L. 1964. Viziatkak Hydracarina-Fauna Hungariae, 72. Akademiei Kiado, Budapest, 380 pp.

Thon, K. 1899. Monographie der böhmischen Hydryphantes-Arten. Bulletin International Academie des Sciences, Prague, 8, 55-67.

Tuzovskij, P. V. 1987. [Morphology and Postembryonic Development in Water Mites]. Nauka, Moscow, 172 pp. [In Russian]

Tuzovskij, P. V. 1990. Opredelitel' deutonymphs vodyanykh kleschey [Key to water mite deutonymphs]. Nauka, Moscow, 238 pp. [In Russian] 
Tuzovskij P. V. 2014a. Description of a new water mite species of the genus Hydryphantes Koch (Acari, Hydrachnidia, Hydryphantidae) from Russia. Acarina, 22(2): 122-126.

Tuzovskij P. V. 2014b. On the taxonomic status of the water mite Hydryphantes hellichi Thon, 1899 (Acari, Hydrachnidia, Hydryphantidae). Ecologica Montenegrina, 1(4): 234-243.

Tuzovskij P. V. 2014c. Larval morphology of Hydryphantes clypeatus Thor, 1899, H. dispar Schaub, 1888 and H. planus Thon, 1899 (Acari, Hydrachnidia: Hydryphantidae). Zootaxa, 3869(2): 131-142.

Tuzovskij P. V. 2015a. On the systematic of the water mite Hydryphantes nonundulatus Viets, 1919 (Acari, Hydrachnidia, Hydryphantidae). Acarina, 23(1): 40-48.

Tuzovskij P. V. 2015b. On the systematic of the water mite Hydryphantes prolongatus Thon, 1899 (Acari, Hydrachnidia, Hydryphantidae). Ecologica Montenegrina, 2(2): 78-87.

Tuzovskij P. V. 2016a. A new water mite species of the genus Hydryphantes Koch (Acari, Hydrachnidia, Hydryphantidae) from the Yaroslavl Province of Russia. Ecologica Montenegrina, 5: 35-40.

Tuzovskij P. V. 2016b. Larval morphology of the water mite Hydryphantes samaricus Tuzovskij. Acari,
Hydrachnidia, Hydryphantidae). Acarina, 24(1): 48-51.

Viets, K. 1919. Hydrachnologische Beiträge.IX-X. Abhandlungen des Naturwissenschaftlichen Vereins Bremen, 24(1): 1-24.

Viets, K. 1936. Wassermilben oder Hydracarina (Hydrachnellae und Halacaridae). In: F. Dahl (Ed.), Tierwelt Deutschlands, G. Fischer, Jena, 31, I$\mathrm{X}+1-288,32,289-574$.

Viets, K. 1956. Die Milben des Süßwassers und des Meeres. Hydrachnellae et Halacaridae (Acari). Zweiter und dritter Teil: Katalog und Nomenklator, Jena: G. Fischer, 1-870.

Viets, K. O. 1978. Hydracarina. In: J. Illies (Ed.). Limnofauna Europaea. Stuttgart, G. Fischer, 154-181.

Viets, K. O. 1987. Die Milben des Süßwassers (Hydrachnellae und Halacaridae (part.), Acari). 2: Katalog. Sonderbände des Naturwissenschaftlichen Vereins in Hamburg, 8, 1-1012.

Wainstein, B. A. 1980. [Key to water mite larvae]. Nauka, Leningrad, 238 pp. [In Russian]

Zawal, A. and Dyatlowa, E. 2008. Parasitizing on damselflies (Odonata: Coenagrionidae) by water mite (Acari: Hydrachnidia) larvae from Odessa province (Southwestern Ukraine). Natura Montenegrina, 7: 453-462. 